\title{
Branched chain amino acid metabolism in portal- systemic shunting : experimental studies in the rat
}

Citation for published version (APA):

de Boer, J. E. G. (1984). Branched chain amino acid metabolism in portal-systemic shunting: experimental studies in the rat. [Doctoral Thesis, Maastricht University]. Rijksuniversiteit Limburg. https://doi.org/10.26481/dis.19841214jb

Document status and date:

Published: 01/01/1984

DOI:

10.26481/dis.19841214jb

Document Version:

Publisher's PDF, also known as Version of record

\section{Please check the document version of this publication:}

- A submitted manuscript is the version of the article upon submission and before peer-review. There can be important differences between the submitted version and the official published version of record.

People interested in the research are advised to contact the author for the final version of the publication, or visit the DOI to the publisher's website.

- The final author version and the galley proof are versions of the publication after peer review.

- The final published version features the final layout of the paper including the volume, issue and page numbers.

Link to publication

\footnotetext{
General rights rights.

- You may freely distribute the URL identifying the publication in the public portal. please follow below link for the End User Agreement:

www.umlib.nl/taverne-license

Take down policy

If you believe that this document breaches copyright please contact us at:

repository@maastrichtuniversity.nl

providing details and we will investigate your claim.
}

Copyright and moral rights for the publications made accessible in the public portal are retained by the authors and/or other copyright owners and it is a condition of accessing publications that users recognise and abide by the legal requirements associated with these

- Users may download and print one copy of any publication from the public portal for the purpose of private study or research.

- You may not further distribute the material or use it for any profit-making activity or commercial gain

If the publication is distributed under the terms of Article $25 \mathrm{fa}$ of the Dutch Copyright Act, indicated by the "Taverne" license above, 


\title{
Branched chain amino acid metabolism in portal-systemic shunting
}

\author{
Experimental studies in the rat
}


Copyright 0 1984: J.EG. de Boer.

No part of this book may be reproduced in any form by print, photoprim, microfilm of any other means withou written permission from the author. 


\section{Branched chain amino acid metabolism in portal-systemic shunting}

Experimental studies in the rat

\section{PROEFSCHRIFT}

Ter verkrijging van de graad van doctor in de geneeskunde aan de Rijksuniversiteit Limburg te Maastricht op gezag van de Rector Magnificus Prof. Dr. H.C. Hemker hoogleraar in de Faculteit der Geneeskunde, en volgens besluit van het College van Dekanen, in het openbaar te verdedigen in de aula van de universiteit op vrijdag 14 december 1984 des namiddags te vier uur.

door

Jurjen Elle Geert de Boer

geboren te Amsterdam 
Promotor : Prof. Dr. F. ten Hoor

Co-Promotor: Dr. P.B. Soeters

Referenten : Prof. Dr. E. Holm

Prof. Dr. P.J. Brombacher

Prof. Dr. P. Fürst

Cover design and cartoons: Guus van Rooy.

Press: Wijntjens Druk, Maastricht. 
Wie jaagt mij voort gelijk het noodlot?

,De Ikzelf

die op mijn rug rijdt."

Tagore

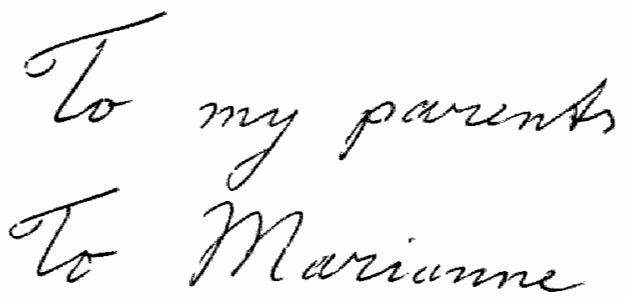




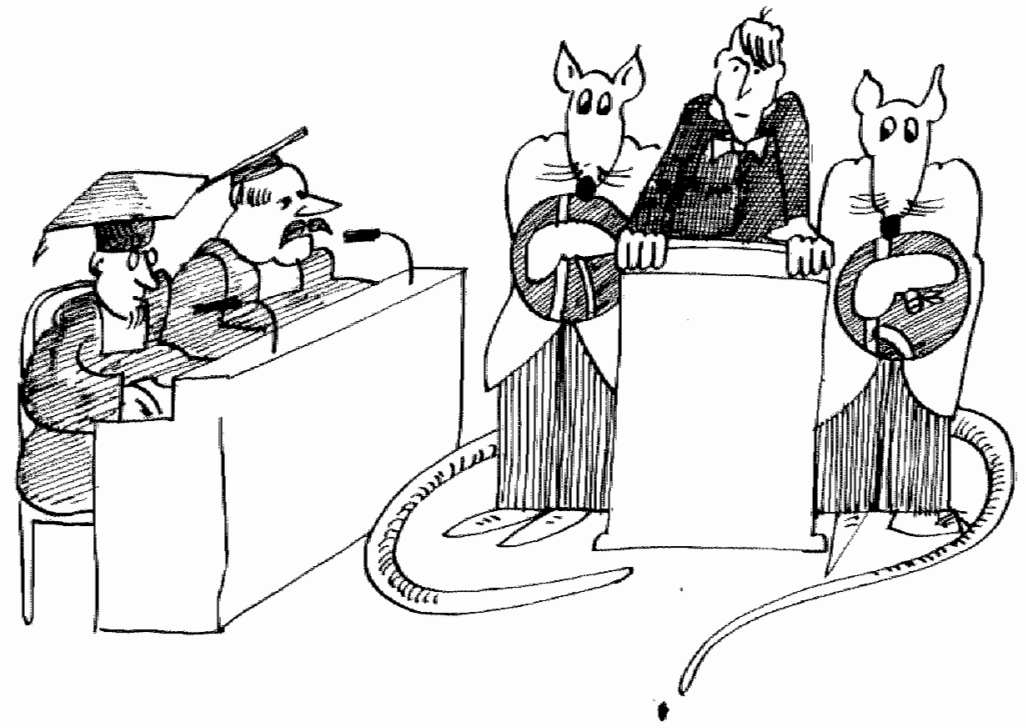




\section{Chapter I: GENERAL INTRODUCTION}

11 Subject of the thesis

Aspects of clinical interest in branched chain amino acids (BCAA)

- Hepatic encephalopathy and amino acid neurotransmitter theory

- BCAA-enriched solutions

- Disease states influencing plasma BCAA-levels

- Malnutrition and starvation

- Diabetes

- Obesity

- Sepsis and trauma

- Liver disease, liver insufficiency and portal-systemic shunting

- The possible role of several organs and tissues in the in vivo regulation of plasma BCAA levels

- Adipose tissue

- Muscle

- Brain, kidney and other organs.

- Liver

- In vitro influence on BCAA-metabolism in non-hepatic tissues; relevance for the in vivo situation

- Sensitivity ta hormones; influence of insulin

- Enzymatic activity

- Transport of BCAA and BCOA 
- Why are plasma BCAA levels decreased in patients with liver cirrhosis and in animals with experimental portal-systemic shunting?

- Outline of this thesis

- References

Chapter II: SEQUENTIAL METABOLIC CHARACTERISTICS FOLLOWING PORTA-CAVAL SHUNT IN RATS

$\begin{array}{ll}41 & \text { - Summary } \\ 41 & \text { - Introduction } \\ 42 & \text { - Materials and methods } \\ 46 & \text { - Results } \\ 51 & \text { - Discussion } \\ 60 & \text { - References }\end{array}$

Chapter III: INFLUENCE OF PORTAL-SYSTEMIC SHUNTING ON LEUCINE METABOLISM IN MUSCLE AND ADIPOSE TISSUE OF FASTED AND FED RATS

$\begin{array}{ll}63 & - \text { Summary } \\ 64 & - \text { Introduction } \\ 65 & - \text { Materials and methods } \\ 66 & - \text { Results } \\ 73 & - \text { Discussion } \\ 81 & \text { - References }\end{array}$

Chapter IV: INFLUENCE OF PORTAL-SYSTEMIC SHUNTING ON ISOLEUCINE AND VALINE METABOLISM IN MUSCLE AND ADIPOSE TISSUE OF RATS

$\begin{array}{ll}85 & - \text { Summary } \\ 86 & - \text { Introduction } \\ 87 & - \text { Materials and methods } \\ 90 & \text { - Results } \\ 99 & \text { - Discussion } \\ 103 & \text { - References }\end{array}$


Chapter V: ACTIVITY OF BRANCHED CHAIN OXO ACID DEHYDROGENASE (BCOA-DH) IN ADIPOSE TISSUE AND DIAPHRAGM OF RATS: THE INFLUENCE OF PORTA-CAVAL SHUNT (PCS)
105 - Summary
$105-$ Introduction
107 - Materials and methods
$109-$ Results
114 - Discussion
$119-$ References

Chapter VI: GENERAL DISCUSSION

137 Addendum

149 Summary

153 Samenvatting

157 Acknowledgements

159 Curriculum vitae 


\section{Abbreviations}

$\begin{array}{ll}\text { AA } & \text { aminoacids } \\ \text { AAA } & \text { aromatic aminoacids } \\ \text { ADP } & \text { adenosine diphosphate } \\ \text { AIB } & \text { a-amino isobutyric acid } \\ \text { ATP } & \text { adenosine triphosphate } \\ \text { BCAA } & \text { branched-chain aminoacids } \\ \text { BCOA } & \text { branched-chain oxoacids } \\ \text { BCOA-DH } & \text { branched-chain oxoacid dehydrogenase } \\ \text { CNS } & \text { central nerwous system } \\ \text { COA/CoASH } & \text { coenzyme A } \\ \text { DNA } & \text { deoxyribonucleic acid } \\ \text { GABA } & \text { Y-aminobutyric acid } \\ \text { FAD } & \text { flavine adenine dinucleotine } \\ \text { HE } & \text { hepatic encephalopathy } \\ \text { IRG } & \text { immunoreactive glucagon } \\ \text { IRI } & \text { immunoreactive insulin } \\ \text { a-KICA-DH } & \text { a-ketoisocaproic acid dehydrogenase } \\ \text { NAA } & \text { neutral aminoacids } \\ \text { NAD }+ \text { NADH } & \text { nicotinamide adenlne dinucleotide } \\ \text { PCS } & \text { porta-caval shunt ing) } \\ \text { PDH } & \text { pyruvate dehydrogenase } \\ \text { PSS } & \text { portal-systemic shunt(ing) }\end{array}$


CHAPTER I

\section{GENERAL INTRODUCTION}

\section{Subject of the thesis}

The subject of this thesis originates from our interest in disturbances in plasma neutral amino acids in patients and experimental animals with liver disease or liver insufficiency. The thesis w11 focus espectally on the decrease in plasma branched chain amino acid levels in liver disease, because that decrease may be relevant for hepatic encephalopathy and for the higher rate of catabolism prevailing in severe hepatic failure. Aspects of basic and clinical interest in branched chain amino acid metabolism will be reviewed in this chapter. Diseases influencing branched chatn amino acid levels will allso be discussed, as well as metabolic factors influencing the degradation of branched chain amino acids at the cellular level. Finally, a short justification will be given of the experiments that were performed.

Aspects of clinical interest in branched chaln amino acids (BCAA)

In recent years, much attention has been focused on several aspects of BCAA metabolism:

* BCAA may serve as alternative fuel in fasting (93), in severe catabollc states (7) and during extensive exercise (110).

* BCAA, especially leucine, may serve as a possible regulator of protein turnover (10). Leucine, in particular, has anabolic effects $(11,16)$. 
* Many clinical conditions, diseases and altered nutritional states, are accompanted by altered BCAA levels in plasma and very often also intracellularly in muscle and other tissues $(2,26,49,50)$.

* A disturbed plasma neutral amito acid (NAA) pattern, including low BCAA levels, is clinically associated with hepatic encephalopathy $(37,70,13$, 122).

* Based upon a normalization of the lowered plasma BCAA levels in several disease states, the administration of BCAA-enriched solutions is advocated and used as a possible therapy for patients with hepatic encephalopathy $(38,43)$ and/or in severe catabollc states such as sepsis $(42,44)$ or trama $(5,41)$. However, there is still no real proof that these solutions, orally or parenterally admintstered, are more beneficial than conventional solutions.

These aspects of BCAA will be discussed briefly.

\section{BCAA: alternative energy substrate}

Extensive exercise, fasting, starvation and catabolic diseases are clinical situations with a net negative nitrogen balance. Shortly after extensive exercise, plasma BCAA levels are slightly decreased in healthy man (33). Semi-starvation and starvation are accompanied by lowered plasma BCAA levels $(26,31)$. Severely catabolic patients or animals, e.g. after trauma or with sepsis or severe liver fallure, also have low plasma BCAA levelg $(2,49,50,67,113)$. It has been suggested that, in these conditions, BCAA may serve as alternative energy substrates $(13,14,54,95,117)$. For some of these condtitons, an Increased uptake and degradation of BCAA in muscle has been reported $(1,103,132)$, and most probably, these BCAA originate malniy from skeletal muscle proteolysis (71). A muscle energy deficit has been proposed (7) and this may be explained by different mechanisms in different clinical states. It 1 s known that during exercise, liver blood flow decreases whereas simultaneously the blood flow to the exercizing muscles increases. While transamination of the BCAA in muscle largely depends upon the delivery of these amino aclds (75), in working muscle transamination and probably further degradation of BCAA may be increased simply because of the increase of blood flow. It is even suggested that, in exerclse, 1 might be advantageous to use amino acids as energy substrate 
(109). However, there is no proof that increased catabolism of BCAA is induced by exercise.

In severely catabolic patients or animals, that have a strongly negative nitrogen balance, the possible explanation is somewhat different. It has been suggested that in these subjects, BCAA may serve as alternative energy substrate when less glucase or lipids are avallable or when these substrates cannot be utilized. It has even been suggested that, in addition to plasma BCAA, these subjects presumably consume thelr own muscle protein to supply energy (7). The shortage of energy in muscle and other organs might be the result of a diminished capacity to utilize glucose and fatty aclds, due to glucose intolerance and insulin resistance, which have indeed been observed after trauma and in sepsis (3a) and have recently also been reported in liver cirrhosis $(6,128)$. The insulin resistance may be due to a decreased number of functional receptors (6) or to post-receptor defects. In addition, the rafsed insulin level might tnhtbit llpolysis resulting in a decreased release of free fatty acids from adipose tissue. However, there is no evidence for decreased lipolysis in cirrhosis, whlch pleads against a muscle energy deficit.

Furthermore, the contribution of BCAA degradation to overall energy metabolism in severe catabolic states can only be of minor importance. In severe disease an adult may loose $20 \mathrm{~g}$ nitrogen per day, which $1 \mathrm{~s}$ equivalent to $120 \mathrm{~g}$ protein. containing $36 \mathrm{~g} \mathrm{BCAA}$. If all this would be muscle protein, these BCAA would furnish $150 \mathrm{cal}$, assuming that complete degradation occurs. Our own data (chapters III and IV) and data from Klpnis group suggest however, that degradation is incomplete and may become even less complete after PCS. This implies that the contribution of BCAA to the total energy coverage may be even less (50-100 cal per day for an adult). This is only a minute part of the total dally energy expenditure (2500-3000 cal). Apparently, the body is able to cover $95 \%$ or more of 1 ts energy needs from other energy sources, even in an extremely catabolic state. Therefore, it is unlikely that muscle proteln degradation would signiflcantly contribute to the energy requirements, espectally in the presence of increased fatty acld avallability. 
Leuclae: anabolic properties and regulator of proteln turnover

A number of factors known to be important for the growth of muscle has been show to alter in vitro the overall rates of protein degradation as well as protein synthesis in sikeletal and cardiac muscle. Among these are glucose, insulin, amino acids, arachidonic acid and prostaglandins $\mathrm{E}_{2}$ and $F_{2}$ a $(53,112)$. Insulin is undoubtedly the most potent and most important physlological factor regulating overall protein balance in skeletal muscle. A rise in insulin levels after meals stimulates the net uptake of amino acids by skeletal muscle and their incorporation into protein. The fall in Insulin postabsorptively and during fasting, slgnals a net release of amino actds from muscle $(28,116)$. In muscle and other tissues, insulin not only stimulates protein synthesis but also inhibits protein degradation $(47,51,52,77,88,107)$. These two hormonal actions have complementary effects In producing net tissue protein gain. The effects on protein synthesis and degradation are also observed in the absence of exogenous glucose or amino acids and thus, are not only the result of the ability of insulin to stimulate nutrient transport (47). Glucose by itself also inhibits protein degradation without, however, affecting protein synthesis (47).

The presence of plasma amino acids stimulates protein synthesis and diminishes protein breakdown. It is evident that all amino acids or at least all essentlal amino acids must be present to be able to synthesize protein. However, the stimulatory effect on proteln synthesis is mainly attributable to the presence of BCAA (78). This belng established, the BCAA were tested on their ability to stimulate protein synthesis, both separately and in combinations. From these studies it was found that leucine in partlcular promotes protein synthesis and inhiblts protein breakdown $(10,11,47,56,78,107)$. No other plasma amino acid has such an influence on proteln turnover. The effects of leucine on protein turnover in muscle have been $\mathbb{1 1}$ ustrated in vitro at concentrations of leucine $(0.1-0.5 \mathrm{mM})$ that are, at least partly, in the physlologlcal range. Therefore, this mechanism of regulation may be active in vivo. In vitro studies demonstrated that proteolysis was progressively inhibited at high leucine concentrations (0.3-1.0 m) (126), that can be present in plasma of patients recelving amino acld mixtures intravenously or as dietary supplements. 
In vitro studies of protein synthesis and proteolysis showed that the presence of a competitive inhibitor of leucine transamination (e.g. cycloserine) dissociated the two anabolic effects of leucine. The inhlbition of protein breakdown requires leucine catabollsm, while the enhancement of synthesis does not $(56,126)$. The a-keto analogue of levine, a-ketoisocaproic acid, seems to be responsible for the inhibition of protein breakdown. Many reports have been published in which infusions of BCAA or leucine alone are claimed to reduce severe protein catabolism in patients with strongly negative mitrogen balance $(5,41,42,43,44)$. In patlents, a-ketolsocaprolc acid infusions have also been claimed to improve nitrogen balance and should even be more effective than leuclne in patients with renal failure ( 87$)$, as $\alpha$-ketolsocaproic acid may have a more rapid transport into cells than leucine (94).

\section{Altered plasma BCAA levels}

Altered BCAA levels in plasma are encountered in health and disease. In healthy subjects, fluctuations of plasima BCAA levels are relatively swall and always transient, e.g. after a protein-rich meal or after an overnight fast. In disease, deviations in plasma BCAA levels are of ten more pronounced and persist over long periods. When normal food intake is maintained, diurnal varlations in plasma BCAA are superimposed on the deviating plasma BCAA levels Induced by the disease, unless (multiple) organ fallure prevents "normal" processing of ingested amino aclds. In several conditions with deviating plasma BCAA levels, intracellular concentrations (mostly based on intramuscular measurements) change proportional1y to the plasma concentrations, as, for example, in starvation $(2,26)$ where both plasma and muscle BCAA concentrations are increased. That this does not always occur, is demonstrated in severe injury and sepsis which are accompanted by strongly increased intramuscular concentrations of BCAA, whlle plasma BCAA are only slightly increased in severe injury $(2,49)$ and are normal or even decreased in sepsis (2). Other diseases with altered plasma BCAA levels are diabetes $(30,130,131)$, obesity $(40)$, renal fallure (74) and 11ver Insufflclency and portal systemic shunting $(67,113)$. The direction of change in plasma BCAA levels in several diseases will be Indicated under: "Disease states influencing plasma BCAA levels". 
Hepatic encephalopathy and amino acld neurotransmitter theory

Hepatic encephalopathy (GE) is a neuropsychiatric syndrome complicating acute as well as chronic hepatocellular fallure and/or portal systemic shunting. Desplte Intensive investigations, mostly in experimental animals, and the demonstration of correlations between possibly involved agents and the mental state (grade of HE) in patients, and desplte the steadily growling amount of information on metabolic changes assoclated with liver fallure, the pathogenesis of HE $1 \mathrm{~s}$ still poorly understood. Recently, Zleve mentioned 20 different abnormalittes in liver fallure which might concelvably contribute to $\mathrm{HE}$ (133).

An abnormal plasma neutral amino acid (NAA) pattern is generally found In patients with liver cirrhosis $(50,67,113)$. This pattern consists of an Increase of aromatic amino actds (AAA; phenylalanine, tyrosine and tryptophan) and decreased levels of the BCAA (leucine, isoleucine and valine). In addition, plasma methionine is often increased. A11 NAA are dependent on the same transport system for thelr passage through membranes (15); this also applies for their transport across the blood-brain barrier $(68,120)$. Consequently, NAA compete for entry across the blood-brain barrier. Entrance of the individual NAA into the brain will be determined by their concentrations in plasma and thus, the plasma pattern will be reflected in the brain. AAA serve as precursors of both normal or physiological neurotransmitters, and abnormal or pathological neurotransmiters. The latter are also termed false neurotransmitters. Normally, tyrosine is the precursor of dopamine and noreptnephrine (and also epinephrine); tryptophan is the precursor of serotonin. Deviations of normal NAA concentrations in brain, and thus, of neurotransmitter precursors, may 1 nduce an abnormal neurotrangmitter pattern in brain. This theory was supported by several studies in experimental animals $(21,23,69)$. Therefore, the distorted plasma NAA pattern in patients with severe liver disease and portal systemic shunting was assoctated with the occurrence of hepatic encephalopathy $(39,70,90$, 122). The first hypothesis which attempted to relate an abnormal neurotransmission to the pathogenesis of $\mathrm{HE}$, in combination with the altered plasma NAA pattern, was the "amino acid - neurotransmitter" hypothesis or

"false neurotransmltter" hypothesis, formulated by Fischer and Baldessarini (36). It was proposed that in liver fallure, the "false" neurotransmlters 
octopamine and B-phenylethanolamine were synthesized from tyrosine and phenylalanine respectively, in preference to dopanine and noreptnephrine (70). The altered neurotransmitter pattern would result in neural inhibition due to the competition of physiological and false neurotransmitters for receptor sites. An analogous mechanlsm might be responsible for increased cerebral levels of serotonin, due to increased cerebral tryptophan. According to this theory, serotonin may contribute to neural inhibition in $\mathrm{HE}$ by blocking its own receptors and by interfering in the degradative pathway of tyrosine to octopamine and norepinephrine, that is controlled, among others, by phenylalanine, tryptophan, false neurotransmitters and serotonin (35). This amino acid neurotransmitter theory stimulated the use of BCAA enriched solutions in encephalopathic patients, with the alm to restore normal brain function. Further investigations ylelded data that supported the orlginal hypothesis, but also data that put restraints on the theory. The theory was readjusted by implicating ammonla, via formation of glutamine, as the agent promoting transport of NAA across the blood-brain barrier (70). Objections have been raised against this theory $(19,34,85$, 133). This leaves room for another theory: the $\gamma$-aminobutyric acid theory * Amino acid neurotransmitters are responsible for almost all neurotransmission in the central nervous system (CNS). About $90 \%$ of all neurons bear receptors for glutamate and about $40 \%$ for $r$-aminobutyric acid (GABA). In mamalian tissues, GABA is produced exclusively in the brain, but gastrointestinal bacteria can also produce GABA. Normally, GABA, released into the portal vein, is almost completely cleared by the 11ver. In Ifver insutficiency, GABA might escape clearance and enter the systemlc circulation. To explain a depressing effect on the brain, increased permeablilty of the blood-brain barrier has been postulated $1 \mathrm{n}$ liver insuffictency because amines cannot enter the brain under normal conditions. Although the theory Is attractive, much work needs to be dome to prove 1ts validity. 0lder theories that suggested short-chain fatty aclds and mercaptans as causal agents for HE $(134,135)$, largely based on correlations between the concentrations of these agents and $H E$, have lost importance. However, using new techniques for the determination of mercaptans in breath and serum $(124,125)$, a positive correlation was reported in clrrhotics with and without HE. The oldest theory, indicating amonia as the toxic agent per se, lost its value as such, but ammonia still may play a role in ex- 
platning the existing Low BCAA levels in liver fallure (76) and may induce a cha1n of events which finally results in changes in neutrotransmission.

\section{BCAA-enrlched solutions.}

The amino acid neurotransmitter theory and the "peripheral muscle energy deficit" theory have advocated and initiated the use of BCAA-enriched solutions in severe liver disease and in severe catabolic states.

Prowiding BCAA-enrlched solutions to severely injured and septic patients, as well as to liver patients would supply metabolizable energy substrates, expecting thereby to obviate the need to break down fibrillar muscle proteln. Moreover, advantage could be taken of the special anabolic effect of leucine by its regulatory role in protein turnover. Infuslons of BCAA solutions into laboratory anfmals and patients with sepsis, stress or (operative) trauma seemed successful. Freund reported an improved nitrogen balance in rats after laparatomy (44), and Blackburn had pasitive results in septic rats (5). In small numbers of patients, uncontrolled trials suggested an efficacious effect by improving nitrogen balance without serious complications $(4,42,97)$. However, reliable double-blind prospective trials have not been reported. Such a trial in our institute did not demonstrate a clinical benefit of BCAA enrichment (unpublished data).

Feeding BCAA-enriched solutions (ar solutions contalining only BCAA) to patients with liver fallure are based partially on the same arguments, serving the same purposes. However, administration of such solutions to encephalopathic or comatose pattents or experimental animals is largely based on the amino acid neurotransmitter theory. The aim is the correction of the pathologic NAA pattern in plasma and consequently in brain, thereby restoring normal concentrations of physlological neurotransmitters and consequently the normal neurological state. In dogs in which encephalopathy was evoked as a consequence of surgical porta-caval shunts, Infusions of BCAA-enrlched solutions seemed beneficlal in suppressing neurological disorders and reducing mortality (121). Many clinical trials in patients have been reported but the results are controversial, ranging from beneficial $(38,96,114)$ to harmful (27). Most studies in this field are not completely comparable, however. The many variables include regimens, quantities of BCAA given, duration of Infusion and above all, the diversity in patients. 
In addition to trials wh BCAA or BCAA-enriched solutions, administered orally or parenterally, trials hawe been started infusing solutions enriched with the a-keto acid analogues of the BCAA. It was assumed that (trans)amination occurs at sufficient rates in the body, thereby lowering the elevated ammonia levels. Especially the ornithine salts of these ketoacids have been used $(64,115)$. Little benefit has been reported until now.

Disease states influencing plasma BCAA levels

The aspects of BCAA metabolism discussed above, recelve much attention nowadays. Extension of knowledge of BCAA metabollsm is necessary, especia11y with regard to regulatory factors in pathologic conditions. The theories mentioned (amino acid neurotransmitter theory and muscle energy deficit theory) and therapies based upon these theorles, originate from the observation that plasma levels of BCAA are decreased in several pathologic conditions. However, the cause of these low levels is still largely unknown.

\section{Malnutrition and starvation}

As early as in 1963, a depression of almost all plasma amino acids, Including the BCAA, has been reported in tropical kwashiorkor (65), a syndrome that is common in the Third World and that is clalmed to arise from diets adequate in calories but grossly defictent in protein.

Simflarly, long-term starvation results, after an initial rtse in plasma BCAA levels, after 2-7 days of fasting in decrease of plasma BCAA levels (31). This decrease becomes more pronounced as starvation progresses (31). Sherwin reported a progresslve decrease in the metabolic clearance rate of leucine throughout starvation (118). From in vivo measurements, there is evidence that the Initial rise in plasma BCAA levels 1 , at least partially, a consequence of a decreased clearance in association with unchanged rates of net release from muscle (106). The later decline in plasma BCAA levels reflects, at least partially, the fact that net release from wuscle tissue falls (32) to an even greater extent than the overall rate of removal from plasma (118). In contrast to the evidence of decreased 
removal from plasma in vivo throughout starvation, in vitro studies indicated an tncrease in leucine oxidation by muscle tissue from fasted rats (55). Seven years later, in vitro studies showed a decreased oxidation of $B C A$ by adpose tissue in starving rats (45). That adipose tissue had a Bignificant capacity to catabolize BCAA, had only just been recognized $(45,121)$. Thus, although adipose tissue has generally not been considered to be of overriding importance in BCAA metabolism, it may, in fact, be responsible for the reduced utilization of these amino acids during starvation. The regulatory mechanism is still obscure.

\section{Diabetes}

For a long time, it has been recognized that insulin plays an important role in the regulation of amino acid metabolism. In accordance with this notion, an altered exchange of amino acids in liver and muscle has been observed in diabetics in both the postabsorptive state and after a protein-containing diet. BCAA are not an exception to this (130). Fasting untreated diabetics have highly elevated plasma concentrations of BCAA (130) and even more 1 increased levels after feeding a protein meal (131). In vitro studies have demonstrated that, in muscle from streptozotocin-induced diabetic rats, BCAA are catabolized to a greater extent, compared with controls (9; unpublished data), despite a less facilitated entry of BCAA Into muscle cells by lack of insulin. These findings, in comblnation with the strongly elevated BCAA levels in plasma, suggest a greatly decreased uptake and utilization of these amino acids at another extrahepatic site. Obviously, adipose tissue is a likely candidate as suggested by decreased. BCAA catabolism $\mathbb{1 n}$ vitro in adpose tissue from untreated streptozotocinInduced dlabetic rats (60; unpublished observations). Moreover, adipose tissue thetabolism of BCAA is readily influenced by lack of insulin.

\section{Obesity}

Obese subjects have normal or slightly increased plasma BCAA levels in the postabsorptive state and greatly increased levels in the fed state (40). Entrance of BCAA into peripheral tissues is hindered by the existing insulin resistance. In vitro experiments with tissues from obese Zucker 
rats ( $\mathrm{fa} / \mathrm{fa}$ ) and from their lean littermates (Fa/fa), showed a decreased oxidation of leucine in both muscle and adipose tissue in the obese group, even in the fasted state. Diminished uptake and utflization of BCAA, due to insulin resistance may therefore, at least partially, be responsible for the high circulating BCAA levels in plasma in obesity.

\section{Sepsis and trauma}

Plasma BCAA levels have been shown to be depressed in pattents whth sepsis $(2,42)$ and trauma $(2,26,49)$. In recent investigations, it was demonstrated that severe trauma and sepsis are associated with tissue depletion of energy-rich compounds and a decreased cellular energy level (79). These findings might be in accordance with the proposed energy deflctt theory. In sepsis and severe injury, muscle cells may oxidize BCAA to compensate for reduced intracellular oxidation of glucose (95) and, in general, for fnadequate degradation of energy substrates (117). In sepsis and trauma Intracellular glucose concentrations are increased tenfold (P.Fürst, personal commication) and plasma fatty acids are also increased. This suggests an impairment of substrate use, rather than lack of fuel avallability in the cell. A role of degradation of $B C A A$ in the malntenance of the energy charge of the cell is still unclear. Therefore, low plasma BCAA leve1s in sepsis and trauma can not yet been explained.

\section{Liver disease, liver insuffictency and portal-systemic shunting}

Disturbances in the plasma NAA pattern have been reported in liver disease, in man $(67,113)$ and in experimental antmals with liver insufficiency and/or portal-systemic shunting $(48,121)$. AAA, etther from exogenous or from endogenous sources, are exclustvely broken down by the 1iver, where the carbon skeleton may be degraded completely to $\mathrm{CO}_{2}$ or may be used as substrate for gluconeogenesis. Consequently, it is not surprising that elevated plasma levels of AAA are observed in both acute and chronic forms of decreased liver function. In addition, free tryptophan levels are increased, altering the bound:free ratio. Th1s is due to competition with increased concentrations of fatty actds for binding sites on albumin whlch is generally low in concentration. As a result, increased levels of free 
tryptophan contribute to the increase of plasma AN in liver fallure. However, decreased plasma levels of BCAA are part of the deranged AA pattern in chronic llver fallure. In acute liver fallure, plasma BCAA levels are approximately normal $(108,113)$. BCAA are unique in that they are the only essential amino acids (EAA) that are almost exclusively metabolized extrahepatically. Hepatic uptake of BCAA from portal venous blood is less than $15 \%(3)$. Muscle $(55,93,119)$, adipose tissue $(57)$, brain $(93,119)$ and kidney $(55,119)$ are able to metabolize $\mathrm{BCAA}$ to $\mathrm{CO}_{2}$. The perlpheral breakdown of BCA can only explatn why plasma BCAA levels are not Increased in liver fallure. Explanations for the observed decreased plasma BCAA levels are still speculative. As mentioned before, states of inalnutrition and long-term starvation are accompanied by low plasma BCAA levels. Patients wh liver disease are often malnourtshed and partly starved. Furthermore, it is still unclear whether lowered plasma BCAA are caused by hepatic parenchymatous disease itself or by portal-systemlc shunting. It has been demonstrated in dogs (123), that porta-caval shunting induces low plasma BCAA levels 1,2 and 4 weeks post-operatively. At these time points the dogs were happy, walking and eating dogs. Simllar results will be described for rats in chapter II. This demonstrates that, at least in experimental animals, portal-systemic shunting 1 tself can induce low plasma BCAA levels In the absence of malnutrition or starvation. In addition, parenchymatous disease is no prerequisite to cause the altered plasma AA pattern. It appears to us that a distinction between metabolic changes due to parenchymatous disease and hepatic Inflow is artificial because both entities together determine total hepatic metabolic function.

The possible role of several organs and tissues in the in vivo regulation of plasma BCAA levels

In the physiological situation, plasma BCAA levels vary within narrow limts, even after ingestion of large amounts of proteln or after an overnight fist. It has been briefly mentioned already, that BCAA are almost excluslvely broken down extrahepatically, i.e. In muscle, adipose tissue, brain and kidney, in that quantitative order. It appears that the availability of BCAA partly determines its plasma levels. Postabsorptive plasma 
BCAA levels are lower than levels after a meal. However, the tatal amount of free BCAA, that circulates in the plasma in excess after a meal compared to the postabsorptive state, is negligible compared to the total amount of BCAA ingested. After consumption of a protein rich western meal, only 10-20\% of the ingested BCAA is needed for protein synthesis. Consequently, large amounts of ingested BCAA must be taken up and metabolized in some way after a meal.

\section{Adlpose tissue}

It has been suggested by Goodman $(46,57,59)$ that adipose tissue, in particular, can degrade BCAA and can utllize part of the carbon skeleton for fatty acid synthesis. An excess of dietary BCAA might be partly degraded in such a way and some BCAA-derived carbon directly stored in adipose tissue.

Muscle

Muscle might be another important tissue for degradation of BCAA $(55,93)$ but its homeostatic role in BCAA metabolism may be limited for several reasons:

* Protein synthesis cannot serve to store quantitatively important amounts of BCAA because, as mentioned, only a small part of the BCAA ingested is used for protein synthesis.

* Only degradation of the carbon skeleton may fulftl a homeostatlc role because storage of BCAA-derived carbon into fatty acids in muscle is negligible (93). Degradation is inhlbited when energy stores (ATP, phosphocreatine and glycogen) become saturated. Th1s accurs readlly during or after a meal when the organism switches to storage, instead of combustion.

\section{Brain, kldney and other organs}

It has been reported that brain and k1dney can degrade BCAA $(55,93$, 119). The contribution of these organs to total BCAA catabolism in the body is, due to their small size, quantitatively unimportant. Th1s is illustra- 
ted in table $I$, in which the trreversible degradation of ${ }^{14} \mathrm{C}-(1)$-L-leuclne (G.a. $0.25 \mathrm{mCi} /$ mol; [ [leuclne] $=0.1 \mathrm{~m}$ ) in several organs is 1 isted. The repotted activities must be viewed as appraxinate activities, because Identical conditions, optimized for diaphragm and adipose tissue, were used for all organs. We realize that these conditions are suboptimal for skeletal muscle in which no perfect linearity of the recorded activity was measured wh respect to tissue welght and reaction time, most probably indicating a limitation in the diffuslon of substrate. Therefore, we made

\section{IRREVERSTBLE LEUCINE DEGRADATION}

\begin{tabular}{|c|c|c|c|}
\hline \multirow[t]{2}{*}{ Thssue } & \multirow{2}{*}{$\begin{array}{l}\text { Activity } \\
\text { (pmol/mg. } 90 \text { min) }\end{array}$} & \multicolumn{2}{|c|}{$\%$ of total body activity } \\
\hline & & $\begin{array}{l}\text { based on } \\
\text { skeletal muscle }\end{array}$ & $\begin{array}{l}\text { based on } \\
\text { dlaphragm }\end{array}$ \\
\hline Adipose tissue & 152 & 57.3 & $23 \cdot 5$ \\
\hline Diaphragm & 177 & & 71.5 \\
\hline Skeletal muscle & 31 & 29.8 & \\
\hline Heart muscle & 55 & 0.6 & 0.2 \\
\hline Small intest 1 ne & 18 & 0.4 & 0.2 \\
\hline Brain & 152 & 2.5 & 1.0 \\
\hline Liver & 39 & 5.9 & 2.3 \\
\hline Kidney & 134 & 3.3 & 1.3 \\
\hline
\end{tabular}

Table 1

Irreversible degradation of ${ }^{14} \mathrm{C}-(1)$-L-leucine (s.a. $0.25 \mathrm{mCl} / \mathrm{mol} ; 0.1 \mathrm{~m}$ ) by several organs of normal male Sprague-Dawley rats (approximately $290 \mathrm{~g}$ ), determined in triplicate and expressed in pmol/mg wet welght.90 min $(n=4)$. A rough calculation of the percent contribution of each organ is given, based on organ weights and on the assumption that adipose tissue contributes $15 \%$ to total body welght and muscle $40 \%$. Because of the different activities that were recorded in diaphragm and skeletal muscle, two calculations have been carrled out (see text). 
two rough calculations of the percent contribution of the organs to the total in vitro leucine decarboxylation, based on the recorded activity in skeletal muscle, and based on the recorded activity in diaphragm, assurning that the in vivo activity with optimal substrate supply will more closely resemble the activity recorded in diaphragm (table I). Probably the truth is somewhere in between. The only purpose of this table, however, is to ilustrate that organs other than muscle and adipose tissue are quantitatively less relevant with respect to the degradation of plasma BCAA.

\section{Liver}

Species differences may interfere with the exclusive extrahepatic degradation of BCAA. In rats for example, another mechanism may also operate in homeostasis. After transamination of BCAA in muscle in rats, a significant part of the resulting branched chain oxo acids (BCOA) is released into the circulation $(25,80)$; further degradation can continue in the liver. In man, this is quantitatively unlmportant (25).

In summary, adipose tissue and muscle are quantitatively the nost important organs for the disposal of an excess of ingested BCAA or similarly, for causing decreases in plasma BCAA concentrations. It should be noted, however, that the absolute amount of BCAA that must be metabolized in excess to cause lower plasma levels, 1 s minute (probably 2-3\%) compared with the amounts that are metabolized (degraded and/or ared) after a meal. Furthermore, most BCAA are located intracellularly and this intracellular pool is much greater than the plasma pool of BCAA. Obviously, it is virtually impossible to measure increased degradation necessary to decrease plasma BCAA levels, in vivo. No technique would be sensitive enough to detect these small differences. Therefore, it 18 more appropriate to study in vitro the ablity of peripheral tissues (1.e. muscle and adipose tissue) to degrade BCAA, present at physiological concentrations. The ability to metabolize BCAA in these tissues may be Influenced by several factors:

* Mechanisu(s) for transport of BCAA across membranes of cells and cellular organelles.

* Activity of rate-1imiting enzymes in the degradation of BCAA. 
* Sensitivity of the tissues to hormones exhibiting stimulatory or inhibitory effects, e.g* stimulation of transport over cell membranes or induction of enzyme: in the degradation of BCAA or influencing the ratio of active to total enzyme(s).

In vitro Influence on BCAA metabolism in non-hepatic tissues; relevance for the in vivo situation

The observation in vitro that muscle is able to metabolize BCAA in significant quantitles (93) has led to the hypothesis that lowered plasma BCAA levels result from increased peripheral degradation (90.122). In general, only muscle was held responstble for this increased peripheral breakdown. However, studles from Goodman $(46,57,59)$ and from our awn group (121) suggested that adipose tissue may also have a significant capacity to catabolize BCAA.

\section{Sensitivity to hormones: influence of insulin}

In the literature, several reports suggest an inverse correlation between plasma BCAA levels and plasma insulin levels. Portal-systemic shunting 1 s accompanied by elevated insulin levels and decreased BCAA levels $(67,90,113,122)$. Unsupplied insulin-dependent diabetes is accompanted by low insulin levels and high BCAA levels in plasma $(30,130,131)$. In obestey, insulin levels and BCAA levels are high $(29,40)$, but insulin resistance is present $(73,98)$. In early sepsis (hyperdynamic phase), plasma insulin is increased and BCAA are low (42). The inverse correlation between Insulin levels and BCAA levels, and the demonstration that the human foreara exhiblts a net uptake of BCAA after a bollus injection with insulin (105), suggest a causal relationship between insulin and BCAA and the existence of a general mechantsm to change plasma BCAA levels in several pathological conditions. Possibly plasma insulin may influence plasma BCAA levels by changing the ablitty of one or more peripheral tissues (1.e. muscle and adipose tissue) to degrade BCAA. In that case, Iow BCAA-degradIng activity may be expected in such tissues in diabetes and obesity, and an increased activity in early sepsis, after trama and after portal-syste- 
mic shunting. However, the influence of insulin on muscle and adipose tissue, differs in some way in both physlological and pathological states. When these differences interfere with BCAA metabolism in these tissues, the suggested causal relationship between insulin and BCAA degrading activity may be expected to be observed only in the tissue that is predominantly responsible for the deviated plasma BCAA-levels. In this respect, it is important to note that insulin resistance has been observed with regard to the metabolisw of glucose, in patients with liver disease $(17,18,111)$. Hepatogenic diabetes has already been described before ( 86 ). More recently, this has been ascribed to insulin resistance, partly at the receptor level and partly at the postreceptor level $(6,72)$. It has been the subject of recent studies to investigate whether insulin resistance also affects BCAA metabolism. It was shown, employing insulin-clamp techniques, that cirrhotic patients exhibited "BCAA-intolerance" after a proteln meal $(81,82)$. This suggests that indeed insulin resistance in cirrhotics also applies to BCAA, but $1 \mathrm{~s}$ in contrast with the observed low postabsorptive plasma BCAA levels in liver patients, if hyperinsulinism in cirrhotics would affect plasma BCAA levels. On the other hand, insulin resistance has been demonstrated in monocytes, erythrocytes and muscle (6), but not 1 in adpose tissue (63), considered to be important for disposal of $\mathrm{BCAA}$, and thus for changes in plasma BCAA levels.

\section{Bnzywatic activity}

An altered peripheral metabolism of BCAA might also be regulated at the level of the rate-limiting enzyme(s) in the degradation of BCAA. In most extrahepatic tissues tested, Including muscle and adipose tissue $(12,22,59,94)$, the rate-1imiting enzyme in the catabolic pathway of BCAA is the branched chaln oxoacid dehydrogenase (BCOA-DH; EC 1.2.4.4.), sometimes also indicated as branched chain axoacld decarboxylase or named after the particular branched chaln oxo acids: a-ketolsocaprolc acid (keto-leuctne), a-keto- $\beta$-methyl valeric acid (keto-isoleucine) and a-keto isovalertc acid (keto-valine). To avold confusion, the term dehydrogenase is used in this thesis, because some decarboxylating activity 1 s reported to be present in the cytosol of liver cells, catalyzed by an enzyme that is independent of some co-factors required for $\mathrm{BCOA}-\mathrm{DH}$ activity (1.e. $\mathrm{NAD}^{+}$and $\mathrm{CoASH}$ ), and 
exclusively reacting with a-ketoisocaprolc acld as substrate $(61,84)$. The first step in the degradative pathway of BCAA is the reversible transamination of the amino group to a-ketoglutarate, catalysed by branched chain aminoacid a-oxoglutarate amino tranferase (EC 2.6.1.6.) (fig.1), producing glutamate and the corresponding branched chain oxoacids. BCOA-DH 1s the second enzyme linvolved in the degradation of BCAA. While the transaminase 1 s rate-11miting in 11 ver (119), the dehydrogenase appears, as already mentloned, to be rate-ilmiting in other tissues $(12,22,59,94)$. $\mathrm{BCOA}-\mathrm{DH}$ is located on the inner surface of the mitochondrial inner membrane, as reported for liver, kidney and muscle cells (83). BCOA-DH, not yet isolated in pure form, has many simllarities with the well known pyruvate dehydrogenase (PDH) enzyme complex $(20,104)$, which is also located at the Inner surface of the Inner mltochondrial membrane. Like the PDH-complex, the BCOA-DH complex has a high molecular welght (about $3 \times 10^{6}$ dalton) and contalns three enzymes: $\mathrm{BCOA}-\mathrm{DH}$, dihydrollpoyl transacetylase and dihydrolipoyl dehydrogenase. Both enzyme complexes, PDH and BCOA-DH, have, in partially purified preparations, the same co-factor requirements: NAD $^{+}$, COASH, dihydrollpoic acid, $\mathrm{FAD}^{+}$and thiamine pyrophosphate (TPP). The similarities go even further. $\mathrm{PDH}$ has two regulatory enzymes: pyruvate dehydrogenase kinase which inactivates PDH in the presence of ATP and $\mathrm{Mg}^{++}$, and pyruvate dehydrogenase phosphatase, which activates the enzyme in the presence of $\mathrm{Mg}^{++}$or $\mathrm{Ca}^{++}(89)$. BCOA-DH is inactivated by phosphorylation and reactivated by dephosphorylation $(66,91,92,99,101)$. The similar location of both enzyme complexes, and especially binding to the membrane, means that both enzymatic activities will be present together in cell free preparations and purifled mitochondrial fractions. However, the BCOA-DH activity seems to be $5 \%$ or less of the PDH activity (46). The possibility that BCOA gerve as alternative substrates for $\mathrm{PDH}$, has been excluded by heat inactivation experiments at $44^{\circ} \mathrm{C}$, by selective inactivation experiments with antibodies directed against $\mathrm{PDH}$ and by competitive inhibition of $\mathrm{BCA}$ $(46,60)$. Another similarity of $\mathrm{BCOA}-\mathrm{DH}$ with PDH is the fact that in vitro activity in adipose tissue can be influenced by insulin $(46,60)$. Although only short-term influence has been reported, this is especially interesting wth regard to the hyperinsulinism noted in liver pattents. Goodman described an increased $B C O A-D H$ activity in adipose tissue segments after short-term preincubation with a high concentration of insulin ( $1 \mathrm{mU} / \mathrm{ml})$. 

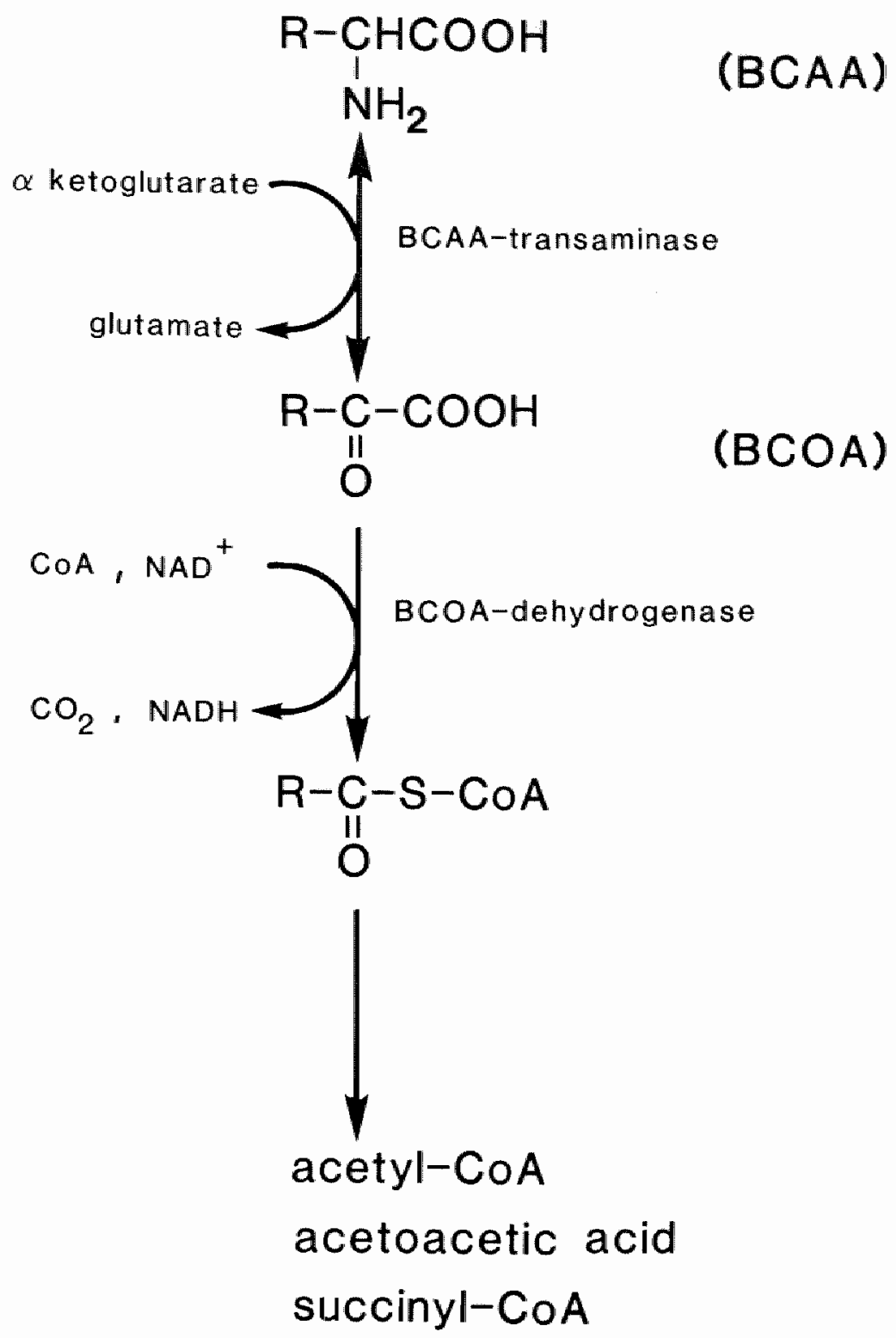

Figure 1

Schematic presentation of the first and second step in the degradation of BCAA. 
This increased activity was maintained after homogenization of the tissue (60). In addition, he reported a short-term influence of insulin in cellfree preparations of adipose tissue, but these effects were only observed when the activity was assayed at substrate concentrations below $50 \mu \mathrm{M}(60)$. Disappearance of the effect of insulin at higher substrate concentrations suggests that insulin might lower the apparent $\mathrm{Km}$ of the enzyme, rather than increase the Vmax. Thls suggestion was confirmed by a shift of the apparent $\mathrm{Km}$ of $101 \mu \mathrm{M}$ to $32 \mu \mathrm{M}$ in a cell-free preparation of adipose tissue, prepared after incubation of whole tissue segments without and with insulin ( $1 \mathrm{mU} / \mathrm{ml})$. However, the insulin concentration ased, was supraphyslological. In muscle and liver preparations, the enzymatic activity can be Influenced by addition of carnitine during the assay $(127,129)$. End-product Inhibition (NADH, CoA-esters) and competitive substrate inhibition ( $\alpha$-oxoaclds, but not pyruvate; some CoA-esters compete with CoASH itself) has been reported $(8,100,104,129)$. In whole tissue, other factors (e.g. muscle work, glucose, fatty acids and $\mathrm{Ca}^{+}$) may influence BCOA-DH activity by interfering with the permeablity of membranes or by providing other metabolizable substrates to cover, for example, energy needs of the cells and thus depending on the type of tissue.

\section{Transport of BCAA and BCOA}

Transport of substrates of $B C O A-D H$ have been investigated in liverand muscle preparations and in blood cells by several authors. In red cells, BCOA transport acrass cell membranes takes place at rapld rates medlated by efther the $\mathrm{Cl}^{-} / \mathrm{HCO}_{3}{ }^{-}$anion transporter or the monocarboxylate transporter as evidenced by the inhibition by specific inhtbitors of these transport systems, respectively a-cyano-a(1-phenylindol-3-yl)-acetate (UK 5099) and difsothiocyanostilbene disulphonic acid (DIDS) (62). Inhibition by a-cyanocinnamate, an Inhibitor of the nonocarboxylate translocator, results in a $60 \%$ reduction of transport of oxoacids over the mitochondrial membrane (102). In contrast to pyruvate transport, the transport of the BCOA does not occur by passive diffuston. A nonmetabolizable amino acid analogue, the a-amino isobutyric acid (AIB), was used as a marker of amino acld transport over the adipocyte membrane, to explore the possibility that insulin might stimulate leucine oxidation by increasing its transport. 
Leucine and AIB share a common cartier system $(57,58)$. Adipose tissue failed to respond to insulin with an increase in the rate of transport of AIB, but AIB was readily concentrated intracellulary to about five times the extracellular concentration after 40 minutes. While increased uptake of BCAA in muscle has been reported in several phystological and pathological conditions $(24,105)$, there are, as yet, no indications that in vitro transport of BCAA or BCOA is limited or stimulated (receptor defects and decreased receptor numbers for insulin excluded) and that transport may have influence on the reported BCOA-DH activities.

Why are plasma BCAA levels decreased in patlents with liver cirrhosis and in animals with experimental portal systemic-shunting ?

It has already briefly been mentioned that plasma BCAA are thought to be decreased in patients or animals with compromised liver function due to Intensified degradation in non-hepatic tissues. The hypothesis was also forwarded that insulin may be instrumental in increased peripheral degradation because hyperinsulinism is common in liver disease and because an Inverse correlation between plasma BCAA and Insulin can be demonstrated in several disease states (90). Neither tissue sensitivity to insulin nor transport seem to play a role in the lowering of plasma BCAA levels. Firsty, if insulin resistance with regard to glucose also applies to BCAA, increased plasma BCAA levels would be expected and second1y, no Indications have been found for altered transport of substrates of the rate-14miting enzyme in BCAA-degradation influencling the activity of the enzyme. Competition with AAA for transport over cell membranes might result in decreased levels of BCAA Intracellularly. Increased levels are found, however. This may be due to increased transport of all NAA as has been demonstrated for brain. Besides the proposed "Insulin-BCAA" theory, it has very recently been suggested (76) that plasma ammonla levels may influence plasma BCAA levels in liver disease. According to this theory, Increased ammonia levels, aften noted in liver disease, might enhance the formation of glutamate from a-ketoglutarate, in the reaction coupled to the transamination of $B C A A$ and formation of $B C O A$, by removing the glutamate for glutamine synthesis. 
Outilne of this thesig

When studying mechanisms underlying the decrease of plasma-BCAA in patients or animals wh compromised liver function, an animal model is needed that exhiblts both hyperinsulinism and lowered BCAA levels. In addition, this animal modell should not suffer from malnutrition, starvation, dlabetes or sepsis. Such an animal model (rats with PCS) is described in chapter II.

Subsequently, in wtro metabolism of BCAA in muscle and adipose tissue of such PCS rats will be studied (chapter III and IV). Incubations are performed with ${ }^{14} \mathrm{C}-(1)-\mathrm{L}$-1eucine and ${ }^{14} \mathrm{C}-(\mathrm{U})-\mathrm{L}-1$ eucine with tissues from overnight-fasted and fed rats (chapter III).

Simllar experiments (only fed state) are described in chapter IV with isoleucine and valine, that will also be tested in these tissues in the presence of unlabeled leucine to explore the reported stimulating effect of leucine on the degradation of the other BCAA. In addition, the fate of BCAA-derived carbon incorporated into fat, will be determined by thin layer chromatography (chapter IV).

While alterations in nembrane transport of $B C A A$ or $B C O A$, as well as insulin receptor or post-receptor defects, are unlikely to be the cause of the changes in in vitro BCAA-metabolism as described, most likely alterations are expected at the enzyme level. Therefore, the activity of BCOA-DH will be measured in muscle and adipose tissue from PCS- and control rats (chapter V). A possible difference in short-term stimulation by insulin of BCOA-DH activity in adipose tissue of these rats will be investigated (chapter V).

Finally the relevance of these findings for the in vivo situation will be discussed and views expressed concerning the presumed pathogenic effects of decreased branched chain amino acid levels (chapter VI).

\section{References}

1. Adlbi S: Rates of branched-chain amino acids in metabolic regulation. $J$ Lab Clin Med 95: 475-484, 1980.

2. Askanazi $J$, Carpentier YA, Michelson CB, et a1: Muscle and plasma amino acids following injury. Influence of inter-current infection. Ann Surg 192: 78-85, 1980 . 
3. Barrett E, Ferrannini E, Gusberg $\mathbb{R}_{\text {, et }} \mathrm{l}$ : Amino acid metabolism by liver and intestinal tissues following aral and $i . v$. amino acids. Clin Res, abstract, 1982.

3a. Black PR, Brockes DC, Bessey PQ: Mechanlsm of insulin resistance following injury. Ann Surg 196: 420-435, 1982.

4. Blackburn GL, Desai SP, Keenan RA, et al: Clinical use of branched chain amino acid enrlched solutions in the stressed and injured patient. In: Walser M, Williamson JR (eds): Metabolism and clinical implications of branched chain amino and keto acids. Elsevier North-Holland, New York, p. 521-526, 1981.

5. Blackburn GL, Moldawer IL, Usi $S$, et al: Branched chain amino acid administration and metabolism during starvation, injury and infection. Surgery $86: 307-315,1979$.

6. Blei A, Robbins D, Drobny $E_{\text {, }}$ et al: Insulin resistance and insulin receptors in hepatic cirrhosis. Gastroenterology 83: 1191-1199, 1982.

7. Border JR, Chenser $M D$, McNemamy RH, et al: Multiple systems organ failure. Muscle fuel deflcit with visceral protein malnutrition. Surg Clin N Am 56: 1147-1167, 1976.

8. Buffington CK, De Buysere MS, Olson MS: Studies on the regulation of the branched chain -keto acid dehydrogenase in the perfused rat heart. J Biol Chem 254, 10453-10458, 1979.

9. Buse MG, Herlong HF, Wiegand DA: The effect of diabetes, insulin and the redox potential on leucine metabolism by isolated rat hemi-diaphragm. Endocrinology 98: 1166-1175, 1976.

10. Buse MG, Reid SS: Leucine, a possible regulator of protein turnover in muscle. J Clin Invest 56: 1250-1261, 1975.

11. Buse MG, Wlegand DA: Studies concerning the specticity of the effects of leucine on the turnover of protein in muscle of control and diabetic rats. Biochim Biophys Acta $475: 81-89,1977$.

12. Chang TW, Goldberg AL: The origin of alanine produced in skeletal muscle. J Blol Chem 253: 3677-3684, 1978.

13. Chang TW, Goldberg AL: The metabolic fates of amino acids and the formation of glutamine in skeletal muscle. J Biol Chem 253: 3685-3695, 1978.

14. Chang TW, Goldberg AL: Leucine inhibition of glucose and pyruvate in skeletal muscles during fasting. J Blol Chem 253: 3696-3701, 1978.

15. Christensen HN: Some special kinetic problems of transport. Adv Enzymol 32, 1-20, 1969.

16. Chua B, Sfehl DL, Morgan HE: Effect of leucine and metabolltes of branched chain amino aclds on protein turnover in heart. J Blol chem 254: 8358-8386, 1979.

17. Collins $J$, Crofford $O B$ : Glucose intolerance and insulin resistance in patients with Liver desease. Arch Int Med 124: 142-148, 1969.

18. Collins RJ, Lacy WW, Stlel JN, et al: Glucose intolerance and insulin resistance in patients with 1 iver disease. Areh Int Med 126: 608-614, 1970.

19. Cullleret $G$, Pomier-Lyrargues $G$, Pons $F$, et al: Changes $1 n$ brain catecholamine levels in human cirrhotic hepatic encephalopathy. Gut $21: 565-569,1980$.

20. Danner DJ, Lemon SK, Besharse JC, et al: Purification and characterization of branched chain a-keto acid dehydrogenase from bovine liver mitochondria. J Biol Chem 254,5522-5526, 1979.

21. David JC, Dairman W, Udenfriend S: Decarboxylation to tyramine: A major route of tyrosine metabolism in mammals. Proc NatI Acad Sc1. USA 71: $1771-1775,1974$. 
22. Dawon AJ, H1rd EJR: Oxidation of L-valine by rat kidaey preparations. Arch Blochem Biophys 122: $426-433,1967$.

23. Dodsworth JM, James JH, Cummings MG, et al: Depletion of brain norepinephrine in acute hepatic coma. Surgery 75: 811-820, 1974.

24. Ella $M$, Farrell $R$, Ilic $V$, al: The removal of infused leucine after injury, starvation and other conditions in wan. Clin sci 59: 275-283, 1980.

25. Ella $M$, Livesey $G$ : Branched chain amino acid and oxo acld metabollsm in human and rat muscle: In: Walser M, Williamson JR (eds): Metabolism and clinical implications of branched chain arano and keto-acids. El sevier North Holland, New York, p. 257-262, 1981.

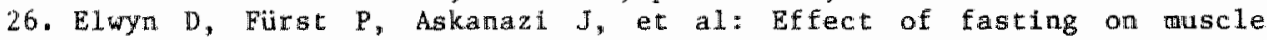
cancentrations of branched chain amino aclds. In: Walser $M$, Williamson JR (eds): Metabolism and clinical implications of branched chain amino and ketomacids. Elsevier North Holland, New York, p. 547-552, 1981.

27. Ericksson $S$, Wahren $J$ : Fallure of oral branched-chain amino acid administration to improve chronic hepatic encephalopathy. In: Walser $M$, Williamson JR (eds): Metabolism and clinical implications of branched chaln amino and keto-acids. Elsevier North Holland, New York, p. $481-485,1981$.

28. Felig P: Amlno acid metabolism in man. Ann Rev Blochem 44: 933-954, 1975.

29. Felig P, Mariss E: Plasma amino acid levels and insulin secretion $1 n$ obesity. New Eng J Med 282: 811-816, 1969.

30. Felig P, Marliss E, Ohman J, et al: Plasma amino acld levels in diabetic keto-acidosis. Diabetes 19: 727-729, 1970 .

31. Felig $P$, Owen $O E$, Wahren $J$, et al: Amino acid metabolism during prolonged starvation. J Giln Invest 48: 584-594, 1969.

32. Felig P, Pozefsky $T$, Marliss $E$, et al: Alanine: key role in gluconeogenesis. Science 167:1003-1004, 1970.

33. Felig $P$, Wahren $J$ : Amino acid metabolism in excercising man. $J$ Clin Invese 50: $2703-2714,1971$.

34. Ferenci P, Schäfer DF, Pappas SC, et a1: Inhibitory and excitory amino acid neurotransmitters in heptaic coma. In: Kleinberger $G$, Deutsch $E$ (eds): New aspects in clinical nutrition. Karger, Basel, p. 485-504, 1983.

35. Fernstrom JD, Wurtman RJ: Braln serotonin content: Physiological regulation by plasma neutral amino acids. Sctence 178, 414-416, 1972.

36. Fischer JE, Baldesarint RJ: False neurotransmitters and hepatic coma. Lancet II: $75-80,1971$.

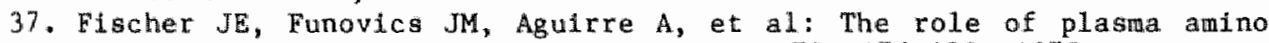
acids in hepatlc encephalophathy. Surgery 78: 276-290, 1975.

38. Fischer JE, Rosen HM, Ebeid AM, et al: The effect of normallzation of plasma amino acids on heptalc encephalopathy in man. Surgery 80: $77-91,1976$.

39. Fischer $J E_{,}$Yashimura $N$, Aguirre $A$, et a1: Plasma amino acids in patients with hepatic encephalopathy: Effects of amino acid infustons. Am J Surg 127: 40-70, 1974.

40. Forlani $G$, Vannini $G$, Marchesini $G$, et 1 : Insulin-dependent metabolism of branched chain amino acids in obesity. Metabolism 33: $147-151,1984$.

41. Freund HR, Hoover HC Jr, Atamian S, et al: Infusion of the branched chain amino acids in postoperative patients. Ann Surg 190: 19-23, 1979. 
42. Freund HR, Ryan JA, Fischer JE: Amino acid derangements in patients with sepsis: treatment with branched chain amino acid rich infusions. Ann Surg 188: 423-430, 1978 .

43. Freund AR, Yoshimura N, Fischer JE: Chronic hepatic encephaolopathy, long term therapy with a branched chain amino acld enriched elemental diet. JAMA 242: 347-349, 1979.

44. Freund H, Yoshimura $N$, Lunetta $L$, et al: The role of branched chain amino acids in decreasing muscle catabolism in vivo. Surgery 83: $611-618,1978$.

45. Frick GP, Goodman HM: Physiological regulation of leuclne metabollsm In rat adipose tissue. Fed Proc 38: 947, (abstract) 1979.

46. Frick GP, Goodman HM: Insulin regulation of branched chain a-keto acid dehydrogenase in adipose tissue. J Biol Chem 255: 6186-6192, 1980.

47. Fulks $\mathbb{R}$, Li JB, Goldberg AL: Effects of insulin, glucose and aulno acids on protein turnover in rat diaphragm. J Biol Chem 250: 290-298, 1975.

48. Funovics J, Cummings M, Shuman L, et al: An improved nonsuture method for porta-caval anastomosis in the rat. Surgery 77: 661-664, 1975 .

49. Fuirst P, Bergström J, Chao L, et al: Influence of amlno acid metabolism in severe trauma. Acta Chir Scand Supp1 494: 136-141, 1979.

50. Fïst $P$, Bergström $J$, Kinney $J M$, et al: Nutrition in postoperative catabolism. In: Richards JE and Kinney JM (eds): Nutritional aspects of care of the critically ill. Churchill Livingstone, Edinburgh, London, 1977.

51. Goldberg AL: Protein turnover in skeletal muscle. J Blol Chem 244: $3223-3229,1969$.

52. Goldberg AL: Influence of insulin and contractile activity on muscle size and protein balance. Dilabetes 28 (1): 18-24, 1979.

53. Goldberg AL: Factors affecting protein balance in skeletal muscle in normal and pathological states. In: Blackburn CL, Grant JP and Young VR (eds): Amino acids, metabolism and medical application, p. 201-211, 1983.

54. Goldberg AL, Chang TW: Regulation and signiflcance of amino acid metabolisin in skelletal muscle. Fed Proc 37: 2301-2307, 1978.

55. Goldberg AL, Odessey R: Oxidation of amino acids by diaphragms from fed and fasted rats. An J Physiol 223: 1384-1391, 1972.

56. Goldberg AL, Tischler ME: Regulatory effects of leuclne on carbohydrate and protein metabolism. In: Wllliamson JH and Walser $M$ (eds): Metabolism and clinical implications of branched chain amino and keto acids. Elsevier North Holland, New York, p. 205-210, 1981 .

57. Goodman HM: Stimulatory action of insulin on leuclne uptake and metabolism in adipose tissue. Am J Physio1 206: 129-132, 1964.

58. Goodman HM: Alpha amino isobutyric acid transport in adipose tissue. Am J Physiol 211: 815-820, 1966.

59. Goodman HM: Site of action of insulin in promoting leuclne utilization in adipose tissue. Am J Physio1 233: E97-E103, 1977.

60. Goodman HM, Frick GP: Metabolism of branched chain amino acids in adipose tissue. In: Walser $M$, Hilliamson JR (eds): Metabollsm and clinlcal implications of branched chain amino and keto-acids. Elsevier North Holland, New York, p. 169-180, 1981 .

61. Grant WD, Connelly JL: Mammalian cytosolic a-keto acid decarboxylase. Fed Proc 34: 640 (abstract 2340), 1975.

62. Halestrap AP: The mitochondrial pyruvate carrier kinetics and specificity for substrates and inhibitors. Blochem J 148: 85-96, 1975. 


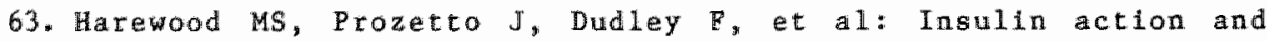
clrrhosis: Insulin binding and lipogenesis in isolated adipocytes. Metabol1sm 31: 1241-1246, 1982 .

64. Herlong HF, Maddrey WC, Walser $M$ : The use of ornithine salts of branched-chain keto acids in portal gystemic encephalopathy. Ann Intern Hed 93, 545-550, 1980.

65. Holt $E_{\text {, Snyderman }} \mathrm{S}$, Norton $\mathrm{P}$, et al: The plasma aminogram in kwaskiorkor. Lancet II: $1343-1348,1963$.

66. Hughes WA, Halestrap AP: The regulation of branched-chain 2-oxo acid dehydrogenase of $\mathbb{1} 1$ ver, kldney and heart by phosphorylation. Biochem I 196: $459-469,1981$.

67. Iber FL, Rosen $H$, Levenson SM, et a1: The plasma amino acids in patients with Liver failure. I Clin Lab Med 50: 417-425, 1957.

68. James $₫ H$, Escourrou J, Fischer JE: Blood-brain neutral amino acid transport activity is fncreased after portacaval anastomosis. Science 200: $1395-1397,1978$.

69. James JH, Hodgman JM, Funovics JM, et al: Brain tryptophan, plasma free tryptoptan and distribution of plasma neutral amino actds. Metabolism 25: 471-476, 1976.

70. James JH, Jeppsson B, Ziparo $\mathrm{V}$, et al: Hyperammemia, plasma amino acid imbalance and blood-brain amino acid transport: An unifled theory of portal systemic encephalopathy. Lancet II: 772-775, 1979.

71. Kinney JM: Surglcal diagnosis, patterns of energy, weight and tissue changes. In: Wilkinson AW, Cuthberson EP (eds): Metabolism and the response to injury. Kent, Potman Medical, 1976.

72. Kolterman OG, Gray RS, Griffin J, et al: Receptor and postreceptor defects contribute to the insulin resistance in noninsulin dependent diabetes mellitis. J Clin Invest 68: 957-969, 1981.

73. Kolterman $O G$, Insel $J$, Sachow $M$, et al: Mechanisms of insulin resistance in human obesity. Evidence for receptor and postreceptor defects. J Clin Invest 65: 1272-1284, 1980 .

74. Kopple JD, Flïgel R, Jones MR: Branched chain amino acids in chronic renal failure. In: Walser $M$, Williamson JR (eds): Metabolism and clinical implications of branched chain amino and keto-acids. Elsevier North Holland, New York, p. 555-567, 1981.

75. Krebs HA: Some aspects of the regulation of fuel supply in omnivorous andmals. In: Wever $G(\mathrm{ed})$ : Advances in enzyme regulation 10: 397 , Pergamon, New York, 1972 .

76. l.eweling $H$, Holm $\mathbb{E}$, Staedt $U$, et al: Intra- and extracellular amino acid concentrations in amonium-infused rats. Evidence that hyperanmonemia reduces BCAA levels. In: Abstractbook 5th International Sympostum on Ammonia, Semmering, Austria, May 16-19, p. 57, 1984.

77. LA JB, Goldberg AL: Effects of food deprivation on protein synthesis and degradation in rat skeletal muscle. Am J Physiol 231: 441-448, 1976.

78. Li. MB, Jefferson LS: Influence of amino acld avallability on protein turnover in perfused skeletal muscle. Blochim Biophys Acta 544: $351-359,1978$.

79. Liaw KY, Askanasi J, Michelsen CB, et al: Effect of injury and sepsis on high-energy phosphates in muscle and red cells. J Trauma 20: $755-759,1980$.

80. Livesey G, Lund P: Enzymatic determination of branched-chain amino acids and 2-axoacids in rat tissues. Transfer of 2-oxoacids from skeletal muscle to liver in vivo. Biochem J 188, 705-713, 1980. 
81. Marchesini $\mathrm{G}$ : Relationship of carbohydrate and amino acid metabollsin. Abstractbook 5 th International Symposium on Ammonta, Semertng, Austria, May 16-19, p. 63, 1984.

82. Marchesini G, Bianchi, Zoll M, et a1: Plasma amino acid response to protein ingestion in patients ith liver disease. Gastroenterology 85: $283-290,1983$.

83. May ME, Aftring RP, Buse MG: Mechanism of the stimulation of branched chain oxoacid oxidation in liver by carnitine. J Biol chem 255: $8394-8397,1980$.

84. May $M E$, Mancusl VJ, Aftring RP, et al: Effects of diabetes on oxidative decarboxylation of branched chain keto acids. Am J Physiol 239: E215-E222, 1980.

85. McGeer PL, Eccles JC, McGeer EG (eds): Molecular neuroblology of the manalian brain. Plenum Press, New York, 1978.

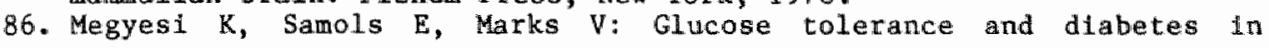
chronic liver disease. Lancet II: 1051-1055, 1967.

87. Mitch WE, Collier VU, Walser M: Treatment of chronic renal fallure with branched-chain keto acids plus the other essential amino acids or their nitrogen-free analogues. In: Walser $M$, willianson $J R$ (eds): Metabolism and clinical implications of branched chain amino and ketoacids. Elsevier North Holland, Mew York, p. 587-592, 1981.

88. Mortimore G: Mechanlsms of cellular protein catabolism. Nutr Rev 40* $1-12,1982$.

89. Mukherjee $\mathrm{C}$, Jungas RL: Activation of pyruvate dehydrogenase in adipose tissue by insulin. Biochem $J$ 148: 229-235, 1975.

90. Munro HM, Fernstrom JD, Wurtman RJ: Insulin plasma amino acid imbalance and hepatic coma. Lancet I: 722-724, 1975.

91. Odessey $\mathbb{R}$ : Direct evidence for the Inactivation of branched-chain oxo-acid dehydrogenase by enzyme phosphorylation. FEBS Lett 121: 306-308. 1980 .

92. Odessey $R:$ Reversible ATP-induced inactivation of branched chain 2-oxo-acid dehydrogenase. Biochem J 192: 155-163, 1980.

93. Odessey R, Goldberg AL: Oxidation of leucine by rat skeletal muscle. Am J Physiol 223: 1376-1383, 1972.

94. Odessey R, Goldberg AL: Leucine degradation in cell free extracts of skeletal muscle. Blochem J 178: 475-489, 1979.

95. O'Donnell TF Jr, Clowes GHA Ir, Blackburn GL: Proteolys1s dssoclated with a deficit of peripheral energy fuel substrates in septic man. Surgery 80: 192-200, 1976.

96. Okada A, Kamata S, Kim CW, et al: Treatment of hepatic encephallopathy with BCAA-rlch amino acid mixture. In: Walser M, WLlliamson JR (eds): Metabolism and clinical implications of branched-chain amino and ketoacids. Elsevier Worth Holland, New York, p. 447-452, 1981.

97. O'Keefe SJD, Trertce MS, Moldawer LL, et al: Protein and energy metabollsw during starvation, low proteln and branched chaln amino acid diets. Fed Proc 37, 751 (abstract), 1978.

98. Olefsky J, Bacon WC, Baur S: Insulin receptors of skeletal muscle: Specific insulin binding slites and demonstration of decreased numbers of sites in obese rats. Metabollsm 25: 179-191, 1976.

99. Parker PJ, Randle PJ: Inactivation of rat heart branched chain 2-oxoacid dehydrogenase complex by ATP. FEBS Lett 95: 153-156, 1978.

100. Parker PJ, Randle PJ: Partial puriflcation and properties of branched-chain 2-oxaacid dehydrogenase of ox 11ver. Blochem J 171: $751-757,1978$. 
101. Parker PJ, Randle PJ: Active and inactive forms of branched chain 2-oxoacid dehydrogenase complex in rat heart and skeletal muscle. EEBS Lett 112: 186-190, 1980.

102. Patel TB, Waynack PP, 01son MS: The effect of the monocarboxylate translocator inhibitor, a-cyanocinnamate, on the oxidation of branched chaln a-keto acids in rat liver. Arch Biochem Biophys 201: $629-635,1980$.

103. Paul $\mathrm{S}$, Adibl $\mathrm{S}$ : Leucine oxidation in diabetes and starvation: Effects of ketone bodies on branched-chain amino acld oxidation in vitro. Metabol1sin $27: 185-200,1978$.

104. Pettit FH, Yeamon SJ, Reed LJ: Purdfication and characterization of branched chatn a-keto acid dehydrogenase complex of bovine kidney. Proc NatL Acad Sci USA 75, 4881-4885, 1978.

105. Pozefsky T, Fellg P, Tobin JD: Anino acid balance across tissues of the forearm in postabsorptive man. Effects of insulin at two dose levels. J Clin Invest 48: 2273-2282, 1969.

106. Pozefsky T, Tancredi RG, Moxley RT, et al: Effects of brief starvation on inuscle amino acld metabolism in nonmobese man. J Clin Invest 57: $444-4.49,1976$.

107. Rannels $\mathrm{DE}$, Kao $\mathbb{R}$, Morgan $H E$ : Effect of insulin on protein turnover in heart muscles. J Biol Chem 250: 1694-1701, 1975.

108. Record $\mathrm{CO}$, Buxton $\mathrm{B}$, Chase RA, et al: Plasma and brain amino acids in fulminant hepatic fallure and thelr relationship to hepatic encephalopathy. Eur J Clin Invest 6: 387-394, 1976.

109. Rennie MJ, Babij $\mathbb{P}$, Halliday $D$, et al: Protein metabolism during exercise. In: Wesdorp RIC, Soeters PB (eds): Clinical Nutrition 1981. Edinburgh, Churcht11 Livingstone, p. 18-34, 1982.

110. Rennie Mal, Edwards RHT, Davies CTM, et al: Protein and amino acid turnover during and after exercise. Biochem Soc Trans 8: 499-501, 1980 .

111. Riggio 0, Merli M, Cangiano $C$, et al: Glucose intolerance in liver cirrhosis. Metabolism 31: 627-634, 1982.

112. Rodemann HP, Goldberg AL: Arachidonlc acid, prostaglandin $E_{2}$ and $F_{2}$ influence rates of protein turnover in skeletal and cardiac inuscle. J Biol Chem 257: 1632-1638, 1982 .

113. Rosen H, Yoshimura $N$, Hodgman $J$, et al: Plasma amino acid patterns in hepatic encephalopathy in differing aetiology. Gastroenterology 72: 483-487, 1977.

114. Rossi-Fanelil F, Canglano $C$, Cuscino A, et a1: The therapeutic effect of branched chain amino aclds in hepatic encephalopathy. Clin Res 27 , $579,1979$.

115. Rossle $M$, Hetz $R$, Gerok $W$ : Treatment of hepatic encephalopathy with an adapted anino acid solution: Influence on amino acid and ammonia concentration $\mathbb{1 n}$ plasma and CSF. Hepatology 1: 541,1981 .

116. Ruderman NB: Muscle anino acid metabolism and gluconeogenesis. Ann Rev Med 26: 245-258, 1975.

117. Ryan NT, Blackburn GL, Clowes GHA Jr: Differential tissue sensitivity to elevated endogenous insulin levels during experimental peritonitis in rats. Metabollsm 23: 1081, 1974.

118. Sherwin RS: Effect of starvation on the turnover and metabolic response to leucine. J Cilin Invest 61: 1471-1481, 1978.

11.9. Shinnick FL, Harper AE: Branched-chain amino acid oxidation by 1solated rat tissue preparations. Biochim Biophys Acta 437: 477-486, 1976. 
120. Smith AR, Rossi-Fanelli F, Ziparo V, et al: Alterations in plasma and CSF amino aclds, amines and metabolites in hepatic coma. Ann Surg 187: $343-350,1978$.

121. Soeters PB: Hepatic encephalopathy, a new perspective for therapy. Thesis. University of Limburg, Maastricht, The Netherlands, 1979.

122. Soeters PB, Fischer JE: Insulin, glucagon, amino acid imbalance and hepatic encephalopathy. Lancet II: 880-882, 1976.

123. Soeters PB, Weir G, Ebeid AM, et al: Insulin, glucagon, portal systemic shunting and hepatic failure in the dog. J Surg Res 23: $183-188,1977$.

124. Tangerman A, Meuwese-Arends MT, Van Tongeren JHM: A new sensittve assay for measuring volatile sulphur compounds in human breath by Tenax trapping and gas chromatography and its application in liver cirrhosis. Clin Chim Acta 130: 103-110, 1983.

125. Tangerman A, Meuwese-Arends MT, Van Tongeren JHM: New methods for the determination of volatile sulphur compounds in human serum and whole blood and its application in liver cirrhosis. J Lab Clin Med: In press.

126. Tischler ME, Desantels M, Goldberg AL: Does leuclne, leucyl-t-RNA, or some metabolite of leucine regulate protein synthesis and degradation in skeletal and cardiac muscle? J Biol Chem 257: 1613-1621, 1982.

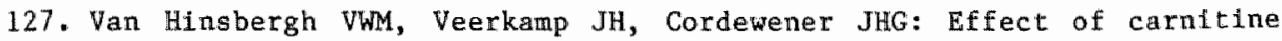
and branched-chain acylcarnitines on the 2-oxoacld dehydrogenase activity in intact miltochondria of rat muscle. Int J Blochem 12: $559-565,1980$.

128. Vannind $P$, Forlani G, Marchesini G, et al: Evaluation of Insulin resistance in liver cirrhosis by means of the glucose clamp technique. Ital J Gastroenterol 13: 255-256, 1981.

129. Veerkamp JH, Van Hinsbergh VWM, Cordewener JHG: Degradation of branched-chain amino acids and 2-oxo aclds in human and rat muscle. Biochem Med 24: 119-129, 1980 .

130. Wahren J, Felig $P$, Cerasi E, et all Spanchnic and peripheral glucose and amino acid metabolism in diabetes mellitus. J Clin Invest 51: $1870-1878,1972$.

131. Wahren J, Felig $P$, Hagenfeldt J: Effect of protein ingestion on splanchnic and leg metabolisu in normal man and in pattents with diabetes mellitus. J Clin Invest 57: 987-999, 1976.

132. Wolfe RR, Goodenough R, Royle $G$, et al: Leucine oxidation during exercise in humans. Fed Proc 49: 900, 1981.

133. Zieve L: The mechanism of hepat1c coma. Hepatology $1: 360-365,1981$.

134. Zleve L, Dolzaki WM, Zleve FJ: Synergism between mercaptans and ammonia or fatty acids in the pathogenesis of hepatic coma. J Lab CIin Med 83: 16-28, 1974.

135. Zieve FJ, Zieve $L$, Doizaki WM, et al: Synerglgm between ammonia and fatty acids in the production of coma: impilcation for hepatic coma. J Pharmacol Exp Ther 191: 10-16, 1974 . 


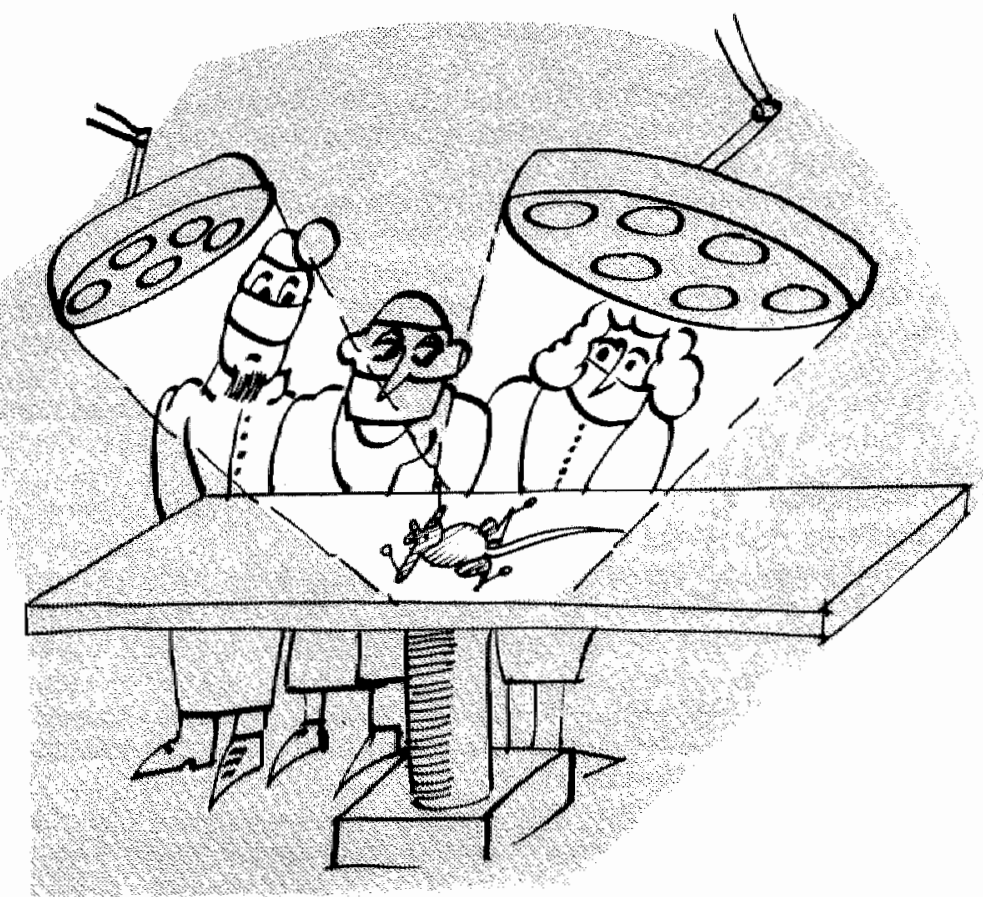


CHATER II

SEQUENTIAL METABOLIC CHARACTERISTICS FOLLOWING PORTA-CAVAL SHUNT" IN RATS

Summary

A porta-caval shunt (PCS) model is frequently employed to study phenomena inherent to portal-systemic shunting of splanchnic blood. In many species, a PCS induces hepatic insufficiency, accompanied by encephalopathy . Rats tolerate a PCS better and exhlbit no or only slight encephalopathy. Moreover, age and environment seem to have a large impact on the ability to tolerate a PCS. This explains the discrepancles between the results of different investigators and the varylng time periods reported between the PCS operation and the optimum time for experiments. To characterize the PCS-model (button technique) in rats with respect to metabolic parameters in our field of interest, we studied three groups of male Sprague Dawley rats (non-operated $(n=12)$, sham-operated $(n=12)$ and PCS-operated $(n=13))$ for four weeks following the shunt operation. Initial body weight was about $200 \mathrm{~g}$. Body welght, plasma anlno acid pattern, plasma immunoreactive insulin (IRI) and plasma immunoreactive gllucagon (IRG) were determined before operation and weekly thereafter. Blood samples were drawn from the venous plexus of the orbita of rats in a 14-16 hr fasted state.

Body weight in the PCS group decreased for one week post-shunt and then increased at about the same rate as in control groups. plasma IRI, IRG and aromatic amino acid (AAA) concentrations were highest one week postshunt, and tended to normalize 1 in the next weeks. Plasma branched chain amino acid (BCAA) concentrations were decreased in the first, second and third week post-shunt, after which normalization occurred. These data demonstrate that after three to four weeks, male Sprague Dawley rats start to recover from the metabolic disturbances caused by the PCS with regard to the parameters measured. Therefore, experiments in this area of interest, especially those relating to BCAA metabolism, should be carried out $2-3$ weeks after the shunt-operation ("button" technique).

\section{Introduction}

Animals with end-to-side porta-caval shunt (PCS) have been used extensively to study the metabolic consequences of the portal-systemic shunting of blood around the liver. In most species, a portal-systemlc shunt even- 
tually leads to hepatic fallure, encephalopathy and death. During the last 10 yeare, alternative theorles have been proposed, linking hepatic encephalopathy to a disturbed neutral amino acid (NAA) pattern $(5,10,12,16$, 20). This pattern has been reported in man and in several animal species and consists of decreased plasma levels of branched chain amino acids (BCAA) and increased levels of aromatic amino aclds (AAA). It has been postulated that the decreased plasma BCAA levels are caused by hyperInsulinism (16), often present in portal-systemic shunting and in hepatic failure. To establish this postulated causality and to gain insight into the underlying mechanism( $s$, an animal model is required which exhibits the altered plasma amino acid profile and hormone level. Rats subjected to PCS are reported to fulfll these criteria $(3,11,13,18)$. Following general guidelines in the 1iterature, we initially used rats 5-5 weeks after a PCS-operation and determined the plasma amino acld profiles, plasma immunoreactive insulin (IRI) and plasma immonoreactive glucagon (IRG). However, no convincing differences could be detected between groups of rats with PCS, sham-operated and non-operated controls with regard to the parameters measured. Apparently, after 5-6 weeks, PCS rats had, at least partly, adapted to the PCS status and had become Indistingulshable in plasma BCAA and IRI levels from control rats. Therefore, it was necessary to redefine our FCS rat model in terms of changes characteristic for portal-systemic shunting (PSS). A serles of relevant parameters, namely body weight, plasma glucose, plasma amino acids, plasma IRI and plasma IRG, were measured before operation and $1,2,3$ and 4 weeks after operation in PCS rats, sham-operated rats and non-operated controls. In addition, a separate group of rats was subjected to splenoportography at $2 \frac{1}{2}$ and $4 \frac{1}{2}$ weeks after a PCSoperation and compared with control rats.

\section{Materials and methods}

Male Sprague-Dawley rats weighing $190-200 \mathrm{~g}$ were used. They were houged under standard laboratory circumstances with a fixed dark-light schedule (dark 19.00 - 7.00; 1ight 7.00 - 19.00), not relocated for at least one week, and were fed regular laboratory rat chow (Hope Farms SRM-A, Woerden, The Netherlands) and water ad libitum. Thirty-seven rats were 


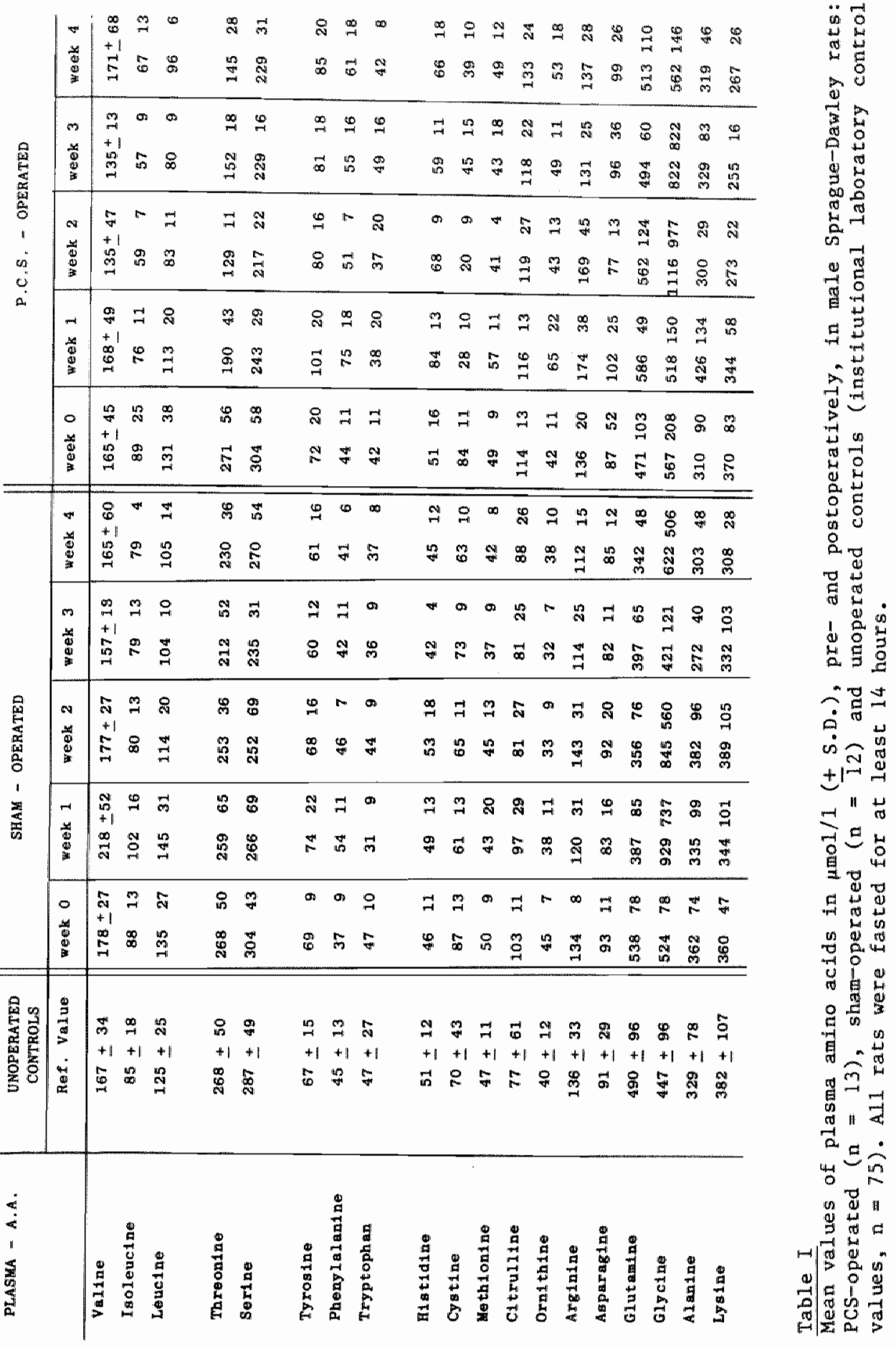


divided into three groups: unoperated controls $(n=12)$, sham-operated rats $(n=12)$ and PCS rats $(n=13)$. PCS operations were performed under ether anaesthesla according to the technique desicribed by Lee and Fisher (14), and modifled by Funovics and Fischer to give a quicker and more uniform "non-suture" or "button" technique (7). The button is made of teflon tube with an Inner dlameter of 1.6 and an outer diameter of $2.3 \mathrm{~mm}$. The PCS operation takes about 25 minutes. The sham-operated group underwent laparotomy and had the portal vein occluded for 10 minutes while the inferior caval veln was partially occluded for 5 minutes. The control group was not treated at a11.

Blood. Two-and-a-half mi of blood was drawn from rats in the fasced state by ocular puncture with hematocrit capiliaries, before and $1,2,3$ and 4 weeks after surgery. The blood was collected in heparinized tubes and cooled on 1ce 1mmediately. From the freshly drawn blood, $0.6 \mathrm{ml}$ was pipetted 1 into a cooled test tube contalning $60 \mu 1$ of the protease inhtbitor aprotinin (Trasylo1 ${ }^{R}$ ) for determination of IRG. Both tubes were centrifuged for 15 minutes at $2000 \mathrm{~g}$ at $4^{\circ} \mathrm{C}$. Plasma was removed and frozen immediately at $-70^{\circ} \mathrm{C}$ unt 11 analysis.

Plasma glucose was determined enzymatically with glucose-oxidase in a Beckman-glucose analyser-2.

Plasma IRI was determined with a commerclally avallable radioimmunoassay kit (Wellcome, Beckenham, England) with human standards and anti-human antisera. The normal range for fasted rats was: $18.2 \pm 8.1 \mathrm{~kJ} / \mathrm{ml}$ (qean \pm S.D.).

Plama IRG was measured with a commercial radiolmmunoassay kit (Biolab, Brussels, Belglum) with human standards and anti-human antisera $30 \mathrm{~K}$. Normal range for fasted rats was: $225 \pm 79 \mathrm{pg} / \mathrm{ml}$ (mean $\pm S . D$. ).

plama amino aclds were determined on a LKB 4400 amino acid analyzer ruming a physiological program with 5 Lit-buffers as described by Dilley and Rocek (4). The plasma was deprotelnized with sulfosalicylic acid (5\% w/v) and filtered through 0.22 m pores (Millipore filters). Narmal values for rats were determined in 75 untreated male Sprague-Dawley rats of about. 200-300 g. (see table I).

In thls study, overnight-fasted values are given for IRI, IRG and amino acids in order to eliminate interindividual varlations due to differences in food intake. 


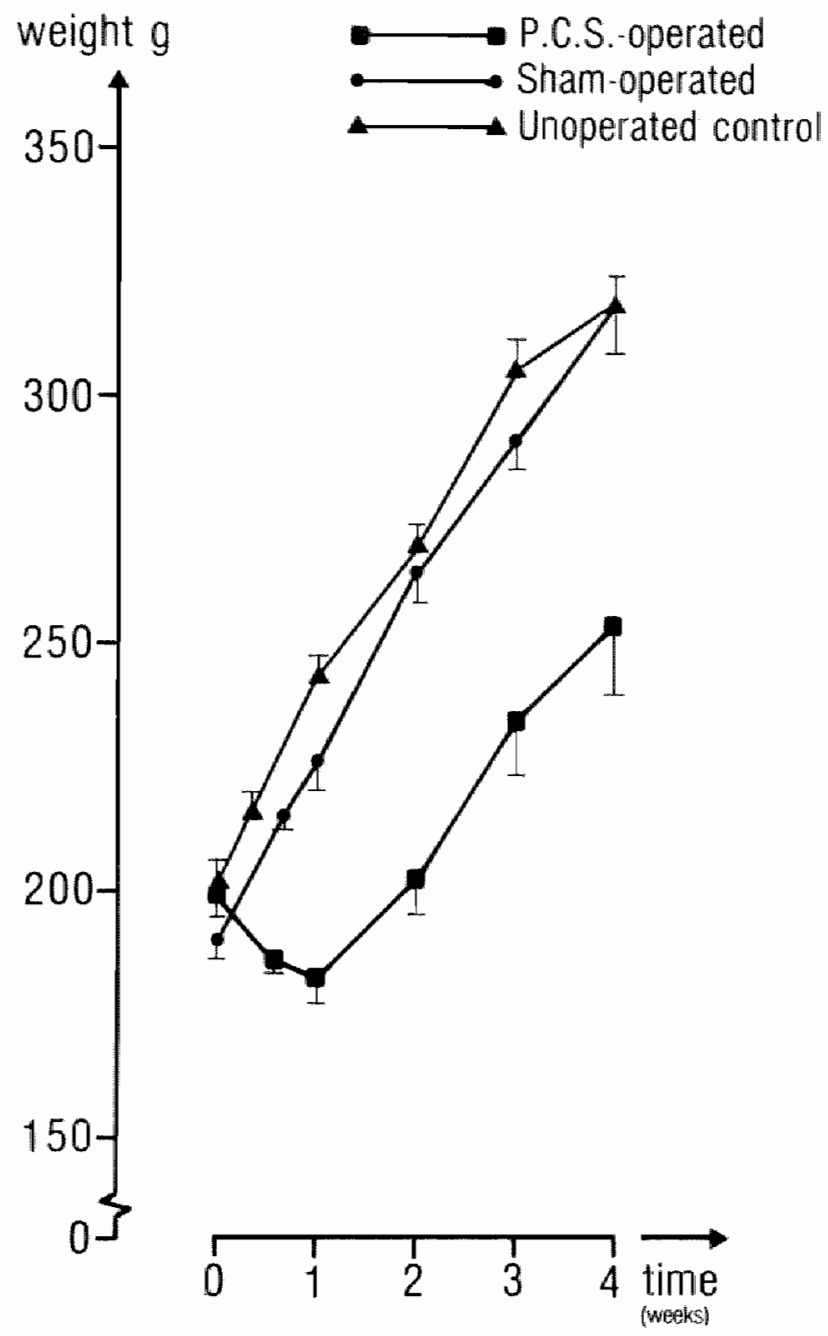

Figure $\mathbb{1}$

Postoperative body weight curves (mean \pm sem) of male Sprague-Dawley rata: controls $(n=12)$, sham-operated rats $(n=12)$ and porta-cava1-shuntoperated rats $(n=13)$, shunted according to the "button" technique. 
For atatictical calculations the Wilcoxon signed-rank test for inter-wekly differences within a group and the wllcoxon rank-sum test for differences between two groups (15) were used.

\section{Results}

\section{Body weight}

Figure 1 shows the body weight curves in PCS-rats, sham-operated rats and non-operated controls. Characteristic in the curve of PCS rats is a welght loss of $5-15 \%$ during the first week after surgery, a minimum body welght 1 week postoperatively $(p .0$.$) and an increase thereafter at a rate$ comparable to that in sham-operated and non-operated control rats. The pre-operative weight of PCS rats is reached two weeks after the operation. As is clear from the standard errors in Figure 1, individual body weight curves of PCS rats exhibut a large variability at 3 and 4 weeks p.o.

\section{Plasma IRI and IRG}

Figure 2 demonstrates that postabsorptive plasma levels of insulin in PCS rats were $60 \%$ higher than the preoperative values $(\mathrm{p}<0.04)$ and the levels of glucagon about $300 \%$ higher $(\mathrm{p}<0.02)$ one week p.o., after which they tended to normalize. Sham-operaced animals showed the same partern but to lesser extent, namely about $10 \%$ rise in insulin ( $p<0.05$ ) and about $100 \%$ in glucagon $(\mathrm{p}<0.02)$ one week $\mathrm{p} .0$. Three weeks after the shamoperation, they were completely normalized. Compared to the sham-operated rats, the pCS anfmals had significantly higher plasma lnsulin levels up to 3. weeks p.o. (44, 51 and $38 \%$ respectively after 1,2 and 3 weeks p.o.) and signiflcantly higher plasma glucagon levels up to at least 4 weeks p.o. (69, 100,113 and $78 \%$ respectively in week $1,2,3$ and 4 p.o.). The nonoperated control groups had normal plasma insulin and glucagon levels throughout the experiment. 


\section{Plasma Insulin}

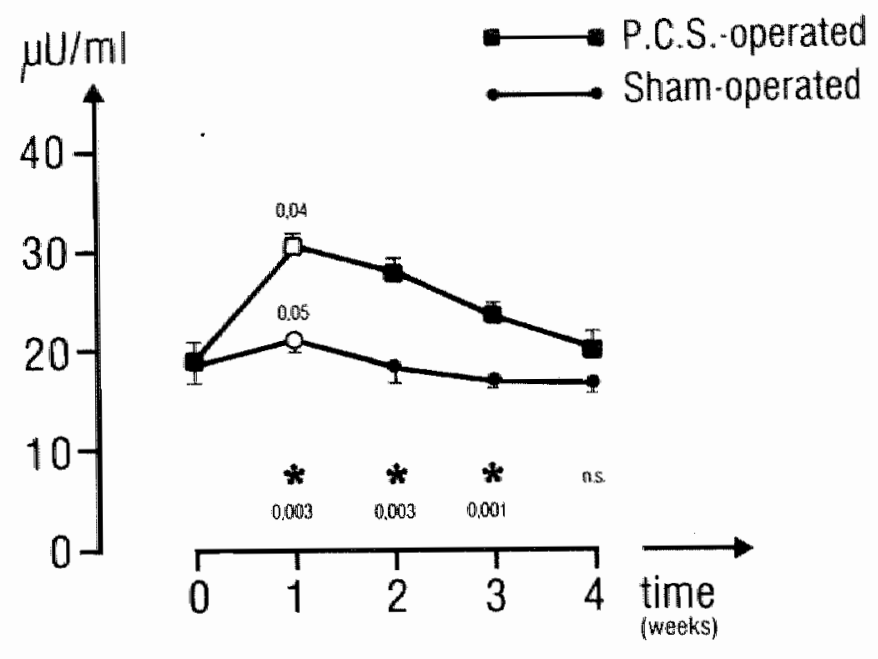

\section{Plasma Glucagon}

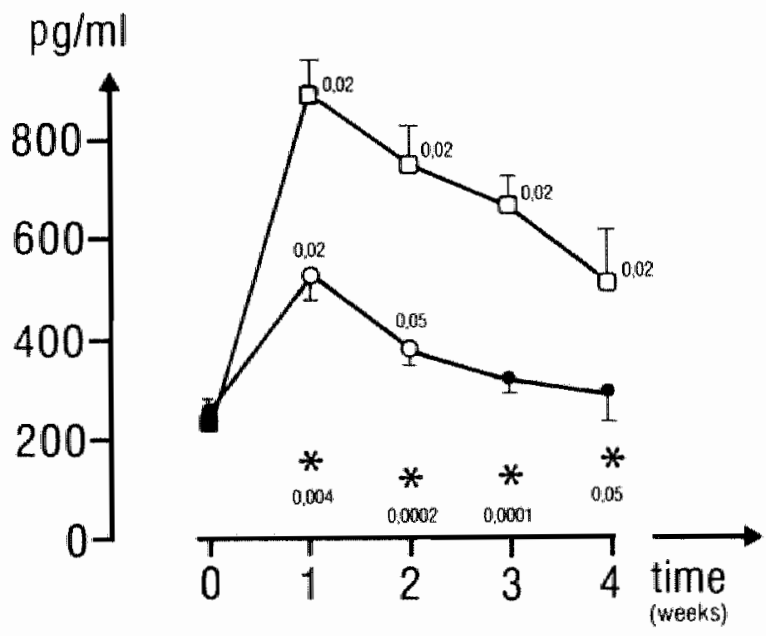

Figure 2

Plasma immunoreactive insulin (IRI) and immunoreactive glucagon (IRG) in sham- and porta-caval-shunt-operated male Sprague-Dawley rats (mean \pm sem). Open symbols indicate statistical significance compared with the pre-operative value. Asterisks above the $X$-axis indicate statistically significant differences between PCS-rats and sham-operated rats. Unoperated controls fell within the normal range (see Materials and methods). 


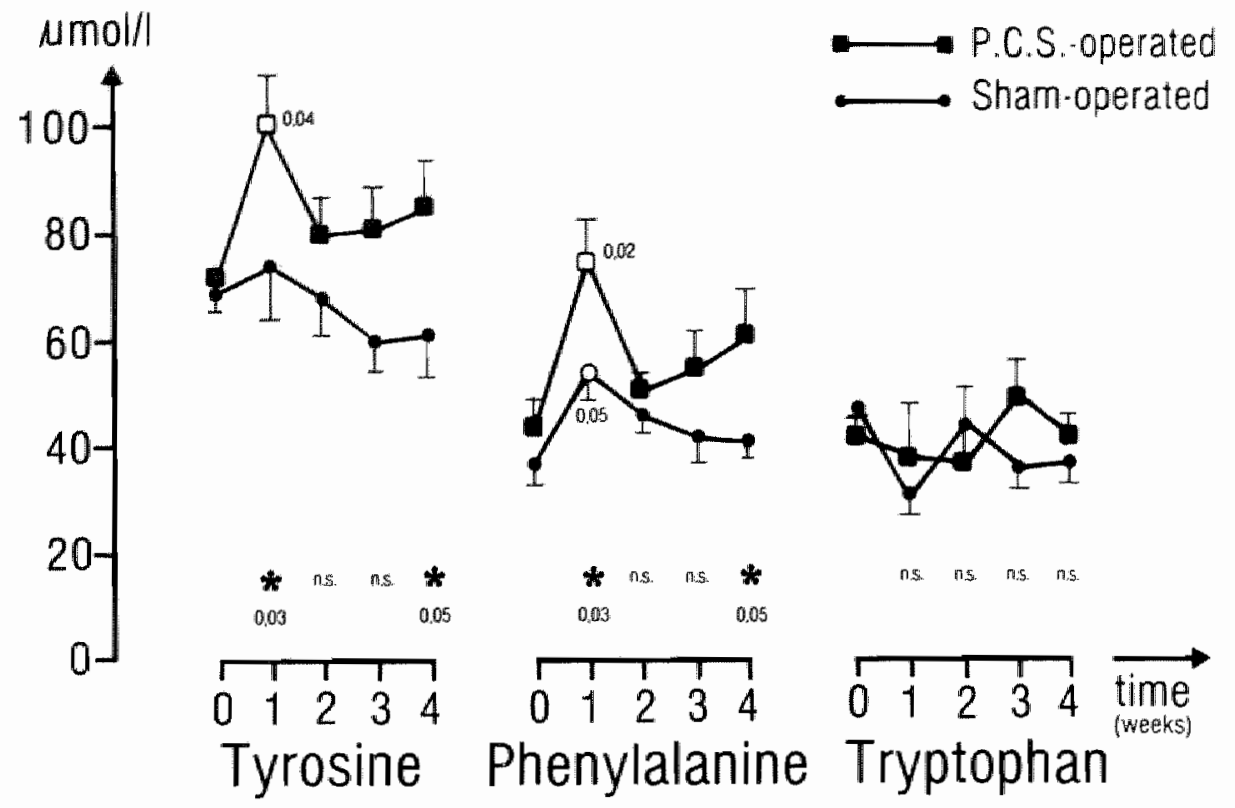

Elgure 3

Plasma aromatic amino acids (AAA; mean \pm sem) in male sprague-Dawley rats; sham- and PCS operated. Unoperated controls fell within the normal range (see table I, first column). Symbols are used as indicated in fig. 2 .

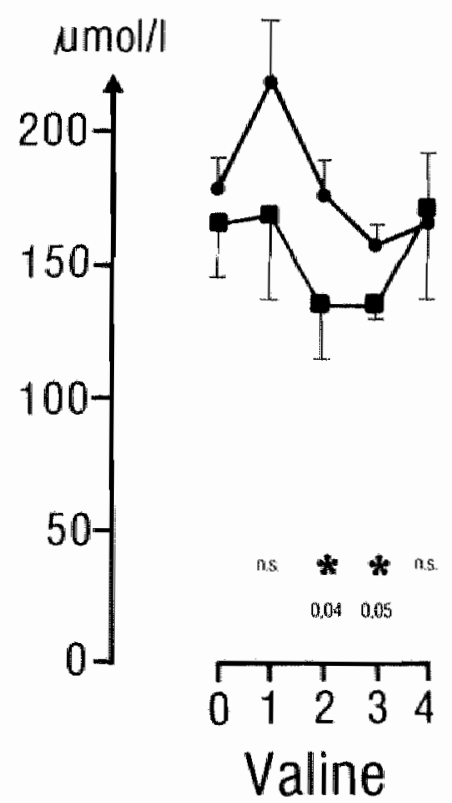

Flgure 4

Plasma branched chain amino acids (BCAA; mean + sem) in male Sprague-Dawley rats; sham- and PCS-operated. Unoperated controls fell within the normal range (see table $\mathrm{I}$, first column). Symbols are used as described in the legend of Fig. 2 . 


\begin{tabular}{|c|c|c|c|c|}
\hline \multirow{2}{*}{$\begin{array}{c}\text { Plasma } \\
\text { Amino acid }\end{array}$} & \multirow{2}{*}{$\begin{array}{c}\text { Time p.o. } \\
\text { (weeks) }\end{array}$} & \multirow{2}{*}{$\begin{array}{l}\text { Direction } \\
\text { of change }\end{array}$} & \multicolumn{2}{|c|}{ Significance $(p)$} \\
\hline & & & PCS vs pre-op. & PCS vs sham. \\
\hline Threonine & $2-3$ & $\varnothing$ & $0.02-0.02$ & $0.002-0.002$ \\
\hline Serine & 2 & $\checkmark$ & 0.04 & N.S. \\
\hline Cystine & $1-2-3-4$ & 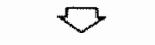 & $0.04-0.02-0.04-0.04$ & $0.003-0.002-0.005-0.005$ \\
\hline Lysine & $2-3$ & $\checkmark$ & $0.02-0.04$ & $0.02-0.02$ \\
\hline Histidine & 1 & 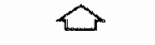 & 0.0 .4 & 0.003 \\
\hline Ornithine & $\mathbb{1}$ & $\triangle$ & 0.05 & 0.01 \\
\hline Glutamine & 1 & 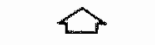 & 0.04 & 0.002 \\
\hline Arg $\mathbb{H i n i n e}$ & 1 & $\measuredangle$ & N.S. & 0.03 \\
\hline
\end{tabular}

Table II

Statistical significances of some plasma amino acids, other than AAA and BCAA, due to portacaval shunting; both compared with the pre-operative value and compared with sham-operated rats (data from table I).

\section{Plasma amino acids}

Plasma amino acid levels in the various groups are listed in table I. Normal values for overnight-fasted unoperated male Sprague-Dawley rats in our laboratory are given in the first column.

Aromatic amino acids (fig: 3)

The plasma levels of the aromatte amino acids (AAA) tyrosine and phenylalanine in the PCS group were signiflcantly increased $(p<0.03$ ) one week after the shunt operation; in the sham group, the plasma phenylalantine level was also signiflcantly elevated $(p<0.05)$ one week p.0., but less than in the PCS-group ( $\mathrm{p}<0.02$; fig. 3, table I). Compared with sham- 
operated rats, the PCS-rats had algnificantly higher plasma levels of tyrosine and pherylalanine $(\mathrm{p}<0.03)$ one week $\mathrm{p} .0$. No significant difference was recorded 2 and 3 weeks p.o. between the PCS group and the sharm group, whlle in week 4 p.o., the difference just reached significance ( $p<$ $0.05)$. Tryptophan was not significantly altered.

Branched chain amino acids

Plabra levels of the branched chain amino acids (BCAA) valine, leucine and isoleucine, are shown in figure 4. In the PCS rats, plasma levels of all three BCAA decreased, stabilized at the low level $2-3$ weeks p.o. and tended to normalize thereafter. Compared to the pre-operative values, levels of leucine and isoleucine in the PCS group 2 and 3 weeks p.o. were slgnificantly lower (leuctne $p<0.02$ and isaleacine $p<0.03$ ). The decrease in valine concentration did not reach statistical significance, due to greater individual variation; in 4 rats, the plasma valine concentration was completely unaffected.

other amino acids than AAA and BCAA, that reached significant differences due to portacaval shunting, are listed in table II.

\section{Splenoportography}

A separate group of rats shunted according to the "button" technique was subjected to splenoportography to evaluate the patency of the shunt with respect to the time-period postoperatively. Each rat had only one gplenoportography. Consequently, regults from different time-periods p.o. are derlved from different rats and may only give a rough indication of PCS-rats with similar body welght curves. PCS rats that galned weight like the rats used in the study described above $(n=7)$, had, $2 t$ weeks p.o. open shunts and no clear collaterals, while the liver was not visualized. In contrayt, in rats that did not gain weight and/or were still under their Initial body welght $(n=4)$, a clear obstruction of the shunt $2 \frac{1}{2}$ weeks p.o. was visualized as well as collaterals to the stomach and esophagus but not to the liver, evidenced by absence of contrast in the liver. All rats subjected to splenoportography $4 \frac{1}{2}$ weeks p.o. $(n=5)$ gained weight, including rats that did not galin weight at $2 \frac{1}{2}$ weeks p.o. All these rats had large collaterals and contrast in the liver, independent of an obstruction of the shunt For representative pictures, see fig. 5 . 
Rats, portacaval shunted according to the "suture" technique $(\mathrm{n}=10)$, lost more weight (fig. 6) than "button"-shunted rats. Additionally, splenoportography was done in 5 of these rats after $2 \frac{1}{2}$ weeks. Hardly any visualisable collaterals were seen and two of the 5 rats had an obstructed shunt* At $4 \frac{t}{2}$ weeks p.o., all rats $(\mathrm{n}=5)$ had an obstructed shunt. Three of these rats had developed collaterals, two of which had contrast in the liver.

\section{Discussion}

In earlier experiments, we could not confirm, 5-6 weeks p.o., the metabollic characteristics described in the literature, using the "nonsuture" technique. Besides the condition of the rats and the time of shumting, other factors may have been responsible for this, including the rat species employed, the technical skill with which the operations were carried out and several enviromental factors. A non-suture technique was chosen because it permits standardization of the operation time, the occlusion time of the portal vein, and within certain limits, the diameter of the anastomosis. The significance of these factors, however, cannot easily be quantified.

In order to eliminate fluctuations in plasma amino acids, plasma IRI and plasma IRG levels due to interindiwidual differences in food Intake, blood samples in this study were taken in the overnight-fasted state. Pair-feeding might circumvent problems of differences in food intake. Rats pair-fed suboptimal amounts of food, however, exhibit an abnormal. eatdrgbehaviour, consuming the food that is granted to them within a relatively short time and starving thereafter. Thus, we declded that pair-fed rats did not form a suitable control group. We did not use post-decapitation blood because analysis of blood obtained by puncture of the retrobulbar plexus of the orbita yields more reliable and reproducible results.

Our findings lead us to conclude that all the above mentioned factors should be standardized as much as possible for a reproducible rat pCs model. Every investigator, before starting experiments, should carefully define his/her own rat model in terms of metabolic characteristics speciftc for the model. 

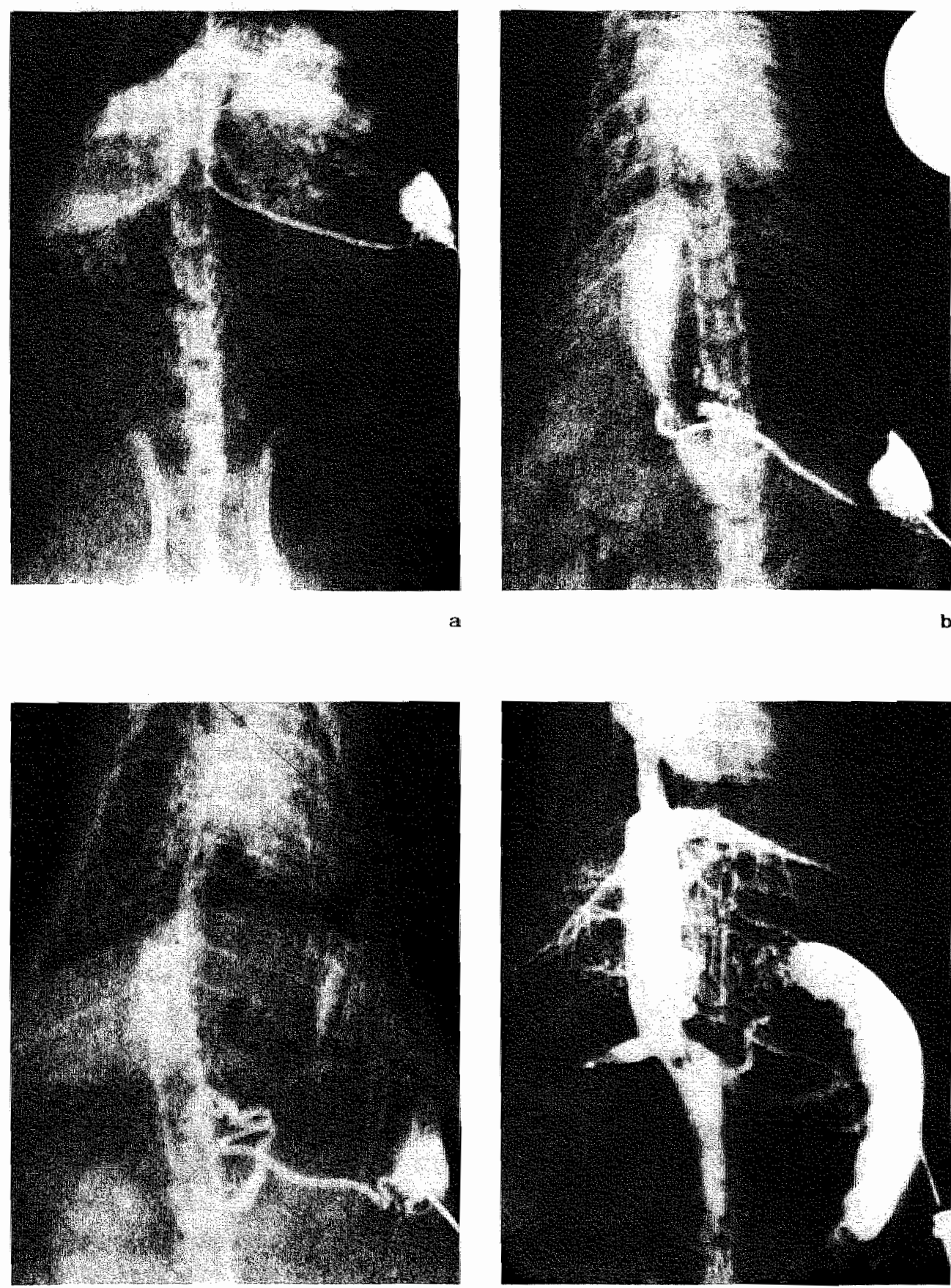


\section{Figure 5}

a. Splenoportography of control rat. Opafication of the spleen, lienal vein and portal vein. Subsequently filling of the whole liver and, at the right side of the picture, some superposition of liver and heart.

b. Splenoportography $2 \frac{1}{3}$ weeks p.o. of button-shunted rat. Opafication of spleen, lienal vein and directly fllling of inferior caval vein (some narrowing due to to the button). No contrast in the Miver, opaflcation in the heart.

c. Splenoportography 2 weeks p.o. of button-shunted rat. Opafication of part of the spleen with subsequently filling of obstructed portal vein. Collaterals are visualized. No contrast tn the liver.

d. Splenoportography $4 \frac{1}{2}$ weeks $\mathrm{p} .0$. of button-shunted rat. Open porta-caval shunt. Opafication of the whole inferior and superior caval wein and extended collaterals resulting in the visualization of the liver.

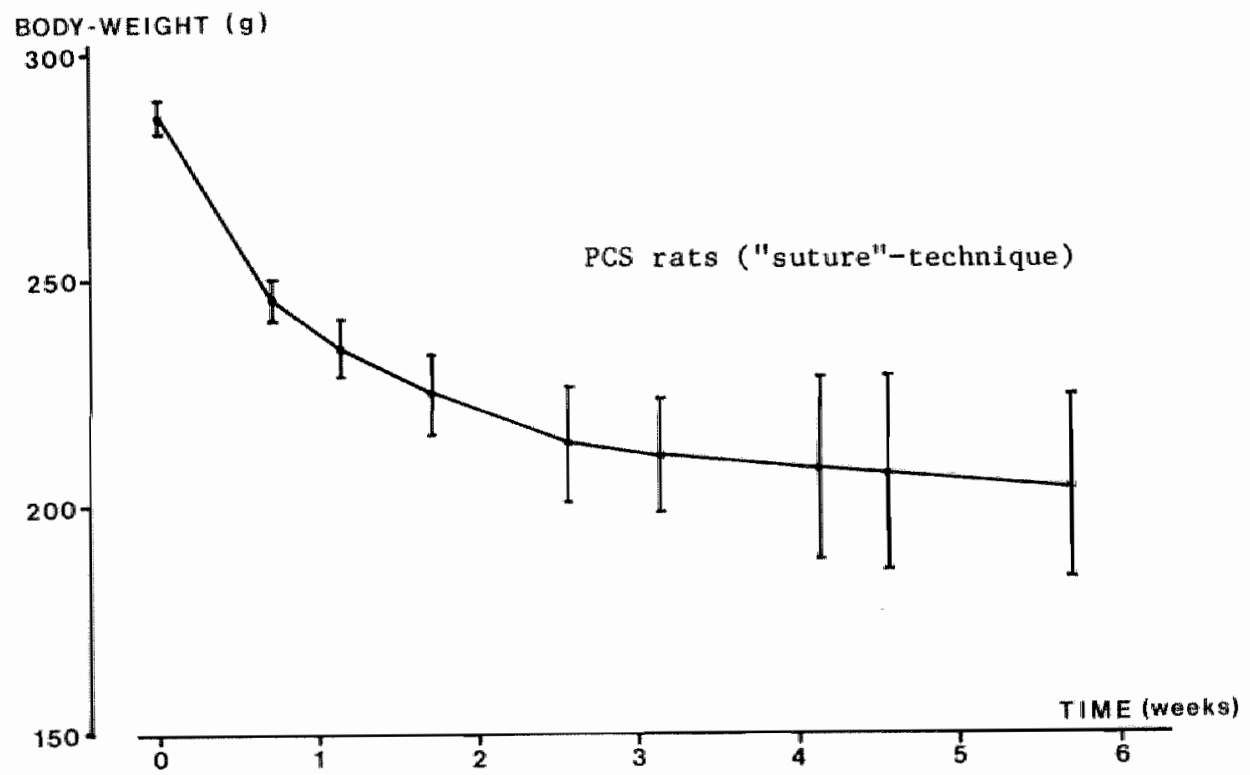

Figure 6

Postoperative body weight curves (mean \pm sem) of male Sprague-Dawley ratis $(\mathrm{n}=10)$, shunted according the "suture" technique. 
Body weight

Reproducible body weight curves were recorded in rats of about 200 grams at the time of the PCS operation. Rats with a body weight below 180 grams had a higher mortality rate and greater variations in body weight and metabol1c parameters after operation. Rats above 300 grams do not tolerate a PCS operation as well as younger rats, exhibiting an increased mortality. Before undergoing the PCS operation, rats should be in optimal condition. Rats suffertng from viral infections, 1ike PPLO or Pasteurella, lose more welght during the first 2 weeks (about 25\%) and do not reach their preoperative body welght unt11 3-4 weeks p.o. Stress due to transport, abnormall nolse, etc. In the week before the PCS operation has a large impact on growth. Pentobarbital anaesthesia, instead of ether, also influences growth. Most investigators report welght 1 osses of up to $30 \%$ or more ( 3,9 , $18,19)$ and lowest body welghts are generally recorded 4-6 weeks p.0.. Preoperative weights are not reached within 6 weeks or even 5 wonths. sham-operated rats, on the other hand, start gaining weight one week after the operation or later, which also contrasts with our results. Initial declines in body weight in the PCS-group are most probably caused by a low food intake. This is suggested from the glucose levels measured in the "fed" state which are comparable to those in fasted rats (fig. 7). The favourable body welght curves in PCS rats after $2-3$ weeks warrant the conclusion that the metabolic changes abserved after 2-3 weeks are specific for porta-caval shunting and are not partly due to undernutrition.

At the time of blood sampling and sacrifice, hematocrits proved to have recurned to normal.

Plama insulin and glucagon

Decreases in plasma BCAA levels have been linked to hypertusulinism (16). It is clear that decreased plasma levels of BCAA 2 to 3 weeks p.o. in the PCS rats, compared to these in sham-operated rats and unoperated controls, are accompanied by a mild hyperinsulinemia (fig..2) together with a three-fold increase in plasma glucagon levels. The mild hyperinsulinemia is observed in all pCS rats 2 weeks p.o., but the levels of insulin in some rats have normalized within 3 weeks. In sham-operated rats, plasma IRG was 
most greatly increased 1 week p.o., probably due to operation trama (fig. 2). High glucagon levels persisted in PCS rats for at least 4 weeks p.o.. In the PCS-operated group, peak values of Insulin and glucagon were observed 1 week p.o. due to PCS and to operation trauma (see shams). This is earlier compared with suggestions in the literature that glucagon levels increase gradually in the first weeks until a stabllized high level $1 \mathrm{~s}$ achleved. No reference value for 1 week $\mathrm{p} .0$. could be found in the literature.

Using the "suture"-technique, Pector et al (18) reported normal. plasma-insulin levels in PCS Wistar rats and in pair-fed sham-operated controls 3 weeks p.o., together with signiflcant hyperglucagonemia in PCS rats compared with the controls. On the other hand, Rossouw et al (19), also using a "suture"-technique, found lower insulin levels in their PCS group compared to the non-operated control group, but their data are apparently derived from fed rats. As their PCS rats were virtually semistarved, insulin levels might have been influenced by the low food intake. Basal insulin levels in a lean "marasmic" pCS rat may be expected to be 10w. This means that equal insulin levels in PCS rats and controls in the "fed" state may be Interpreted as a relative hyperinsulinism in the PCS rats. We used the "non-suture" technique and confirmed the results of Pector e.a. (18) with respect to the hyperglucagonemia; the three-fold rise in glucagon levels was combined with a marginally elevated plasma-insulin level 3 weeks p.o. Our insulin: glucagon molar ratio at the tlme of stabilized altered BCAA levels does not devlate from those reported in the 1iterature $(20,21)$; lowest values were recorded $2-3$ weeks p.o.

\section{Aromatic and branched cha1n amino acids}

Our AAA measurements contrast with reports of highly signiflcant elevations in the plasma levels of all three AAA 4 weeks p.o. and later (11, 13). Tyrosine and phenylalanine were significantly elewated 4 weeks p.o., while 5l weeks p.o. in a separate group of rats, there was only a tendency in the AAA to be elevated (table III). Mo reference could be found in the literature concerning the signiflcantly elevated plasma AAA levels that we recorded 1 week p.o. In PCS rats. Plasma BCAA levels $4 n$ PCS rats were consistently depressed 2 and 3 weeks after operation, whereas these 


\section{Plasma Glucose}

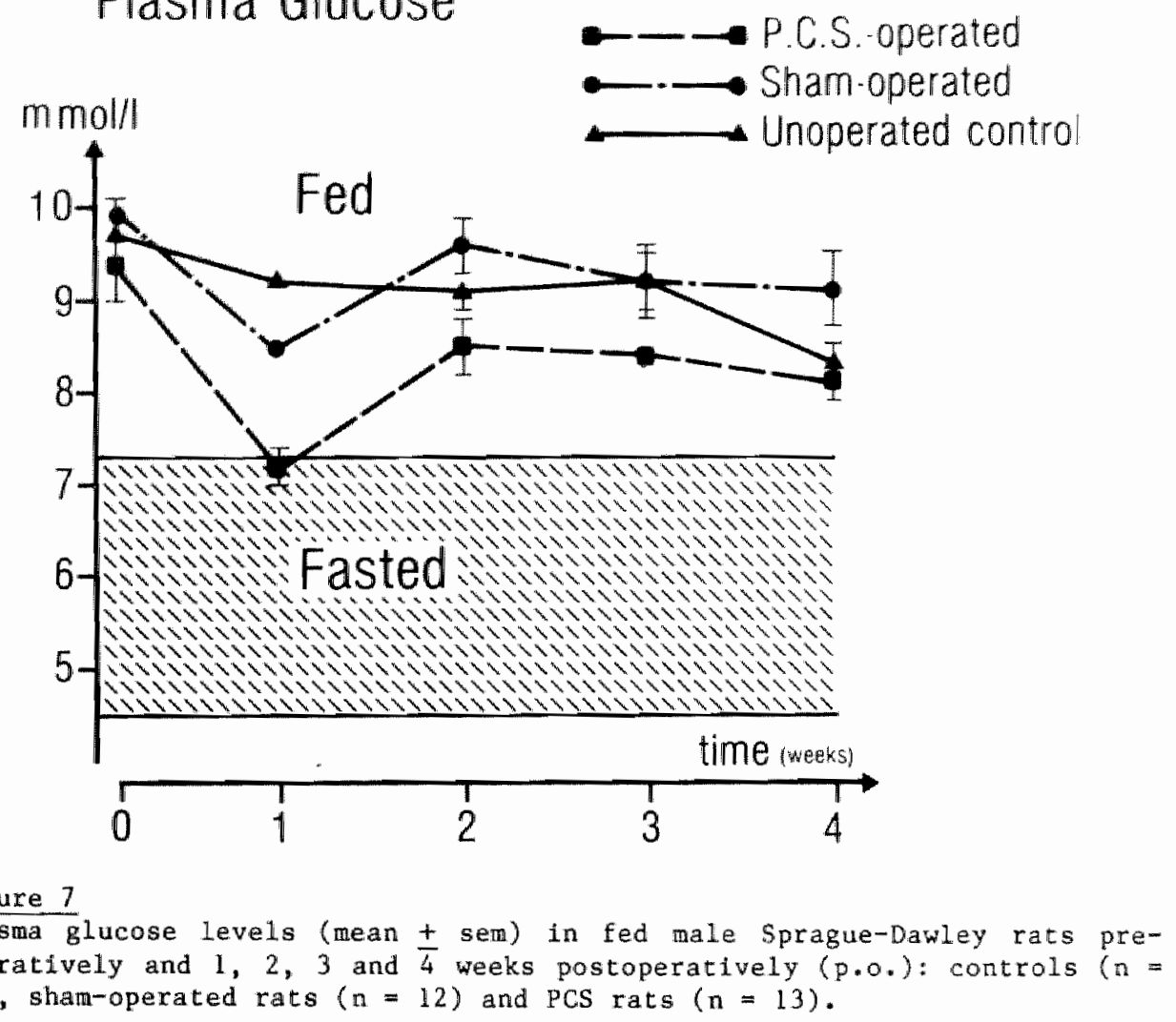

PLASMA NEUTRAL AMINOACIDS

\begin{tabular}{lrc}
$\begin{array}{l}\text { Plasma AA } \\
(\mu m o l / 1)\end{array}$ & $\begin{array}{c}\text { Control } \\
(\mathrm{n}=10)\end{array}$ & $\begin{array}{l}\text { PCS operated } \\
(\mathrm{n}=13)\end{array}$ \\
\hline $\begin{array}{l}\text { Valine } \\
\text { Isoleucline }\end{array}$ & $165 \pm 23$ & $176 \pm 28$ \\
Leucine & $90 \pm 12$ & $91 \pm 15$ \\
Tyrosine & $132 \pm 14$ & $147 \pm 22$ \\
Phenylalandne & $61 \pm 12$ & $74 \pm 9$ \\
Tryptophan & $49 \pm 14$ & $56 \pm 9$
\end{tabular}

Table III

Mean (t S.D.) plasma neutral amino acids (NAA) in PCS ("button"-technique) and control rats 5 l weeks p.o. 
levels were almost normalized at 4 weeks and had completely normalized at $5 t$ weeks $\mathrm{p} .0$. (determined in another group of rats, table III). This is in contrast with reports of decreased BCAA levels 5 or more weeks p*o. (13). The elevated plasma BCAA levels in sham-operated animals and the nomal to slightly decreased levels in PGS rats 1 week p.o. might be explained by operation trauma. Injury alters the plasma AA-pattern. This pattern differs from that observed in other catabolic states and includes ellevated AAAlevels and elevated BCAA-levels (1). That the BCAA levels in PCS-rats are normal, or slightly Increased 1 week p.o., indicates that the mechanism lowering the BCAA is already effective. Significant changes in other plasma amino acids than AAA and BCAA, due to PCS (1isted in table II), are ln good agreement with data from Hawkins et al (9) for "suture"- shunted rats 7-8 weeks p.o. weighing a Iittle more than their pre-operative value, but $40 \%$ less than their controls. Noteworthy is the lowered cystine which is seldon reported.

In an analogous experiment, blood was drawn in the fed state. Determination of the plasma neutral amino acid profile demonstrated that changes in the PCS group were comparable to that of fasted PCS rats when compared with controls. Phenylalanine however, was increased 2-3 weeks p.o. Interindividual fluctuations were greater, probably due to differences in food intake. For the same reason, interpretation of the data for Insulin was not possible.

BCAA : AAA ratio

Experience with the determinations of physiological plasma amino acid profiles in man and rats has proved that an interindividual range of about 15 percent is normal. Porta-caval shunts in man and rats may increase interindividual differences. This means that the ratio of BCAA to AAA has less value in shunted individuals. In a group, however, it is a worthwhlle parameter for a posible correlation with lmpalrment of the mental state. Developing encephalopathy is sald to be indlcated by a decreased BCAA : AAA rat1o (6). For humans and dogs, the normal ratio $(3-4)$ decreases to 1 in coma (20). Assuming that these normal values are also valid for rats, the sham-operated group in our experiment is within the normal range while the shunted group is significantly decreased $1-3$ weeks $p .0$. relative to sham- 
Plasma Ratio $\left[\frac{\text { Leu+lle }+ \text { Val }}{\text { Phe }+ \text { Tyr }}\right]$

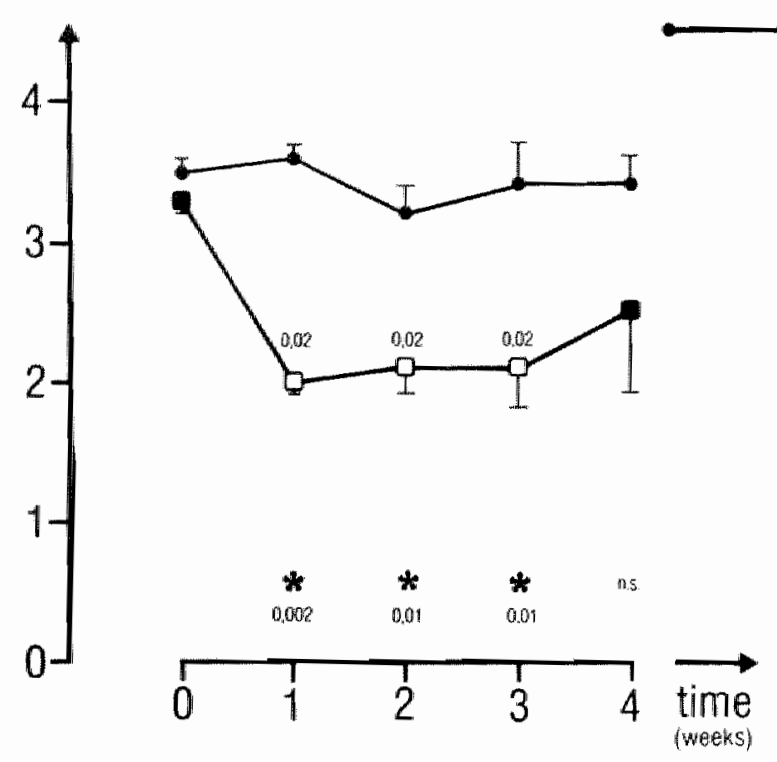

Figure 8

Mean (I sem) plasma ratio of branched chain anino actds (BCAA) and phenylalanine and tyrosine (AAA) in PCS-rats $(n=13)$ and sham-operated rats $(n=$ 12). Symbols are used as described in the legend of $f$ ig. 2 .

opetated rats and to the preoperatlve value (fig. B). Norbalization occurs at 4 weeks $p .0$. No values below 2 were recorded and the rats exhibited no convincing signs of encephalopathy as reported in the literature (8). However, we did not try to quantitate a possible encephalopathy by psychometric tests.

Although ammonia may be one of the factors in the pathogenesis of hepatic encephalopathy, it was not deternined in this study due to the limited amount of blood that could be drawn in in vivo rat experiments. In this way, we diminished the risk of rats developing amemia and thus influencing the results. From other experiments, it is clear that plasma amonia levels are moderately elevated (1.5 - 3 fold) $2 \frac{1}{2}$ weeks after the shunt operation (controls $47 \pm 7$ and PCS $77 \pm 12 \mu$ mol/1; mean \pm S.D.). 
In a study like this, it is Impossible to neasure all the parameters of interest in plasma in the same rats, nor is it possible to record parameters frequently over an extended period because of the limited blood volume avallable and the stress induced by repeated blood sampling. We took all precautions to exclude any other influences on the parameters of interest, except the shunt itself. This study was designed to characterize the PCs rat model operated with a "button" technique, but 1 t was felt necessary to add some findings of PCS rats shunted in our laboratory with the "suture" technique. Drawing definite conclusions is very difficult. There are, in general, important differences between the "suture"- and the "non-suture" PCS rat model, when data from the same time-periods after the operation are compared. Obvious differences exist in growth, encephalopathy, collaterals from the portal area to the liver, 11ver weight, amino actds, glucagon and probably catecholamines. Plasma enzynes (ALT, AST, GLDH and AP) are increased after the PCS-operation in both "non-suture" and "suture"-shunted rats, but tend to normallze, only in the "button"-shunted group, after $3(\mathrm{GLDH})$ or 4 weeks. According to the literature (22), serum IgA levels are also increased in some PCS rats, most pronounced in the "non-suture"-shunted group, Indicating a diminished excretory function (2, 17). The PCS rats selected according to our criteria are relatively healthy rats, only influenced by the shunting of blood around the 11 ver and probably slight portal hypertension which often exists in liver disease and is standardized as much as possible in our model by the use of "buttons" with a standardized internal diameter. Rats shunted with the "mon-suture" technique, that did not fulfil our criteria, and were less healthy, more closely resembled the "suture"-shunted rats. "Suture"-shunted rats are, in general, depleted animals at the time they are used in expertments, conpared with "button" PCS-rats fulfiling our criteria. In our opinton, it 1.s quite possible that parameters measured in "suture"-shunted rats are 1nfluenced by other factors than the shunt itself, e.g. prolonged starvation and malnutrition. The process of normalization of metabollc disturbances of the PCS after 4 weeks in our "button" shunted rats may be due to the ability of rats to adapt when no extreme catabolic state has developed. The forming of collateral blood vessels may be crucial for the normalization, probably favoured by an optimal condition of the rats. The presence of collaterals suggests that some degree of portal hypertenston must be 
present, desplte the fact that care was taken to employ buttons with an Inner diameter that allowed the passage of a normal sized portal vein of rats welghing $200-250$ grams, and desplte the fact that twisting of the portal vein was prevented as much as possible. Close examination af the site of the button at sactifice showed dense adhesions which might cause a slight stenosls. While no 6 igns of infection or pasitive cultures were Found, it is not excluded that silght stenosis develops as a result of a non-bactertal inflammatory reaction due to the presence of a corpus alienum (the teflon button).

\section{References}

1. Askanazi $J$, Elwyn DH, Kinney $M$, et al (in collaboration with Füst $P$, Vinnars $E$ and Bergström $J J)$ : Muscle and plasma amino acids after injury. Ann Surg 188: 797-803, 1978.

2. Birbeck MSC, Cartwright $P$, Mali JG, et al: The transport by hepatocytes of immunoglobulin A from blood to bile, visualized by autoradiography and electron microscopy. Immunology $37: 477-484,1979$.

3. Child GC: The liver and portal hypertension. Major problems in clinical surgery, Saunders, Philadelphia, 1963.

4. Dilley $\mathrm{KJ}$, Rocek PH: In LKB protein chemistry notes 10 and 11 (LKB Biachrom Ltd, Cambridge, England, 1979.

5. Fischer JE, Baldessarini RJ: False neurotransmitters and hepatic coma. Lancet 2: 75, 1971 .

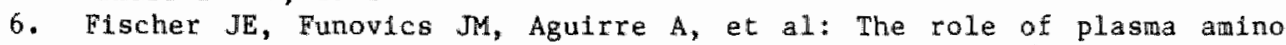
acids in hepatic encephalopathy. Surgery 78: 276-290, 1975.

7. Eunovics JM, Cummings MG, Shuman L, et a1: An improved non-suture method for portacaval anastomosis in the rat. Surgery 77: 661-664, 1975.

8. Grïn $M$, Liehr $H$, Ferenci $P$ : Ausblefben des Eck-Fistel-Syndroms nach Erhalten des portohepatischen Pankreasblutelusses bel portocavaler Anastomose. In: Wewalka $F$, Dragosics B (eds): Aminosäuren, Ammoniak und Hepatische Enzephalopathie. III. Internationales $\mathrm{NH}_{3}$-Symposium, May 1977, Baden bel Wien. Gustav Fischer Verlag, Stuttgart/New York, p. $135-151,1978$.

9. Hawklns RA, Mans AM, Biebuyck JE: Alterations in arino acid transport across blood-brain bartier in rats following portacaval shunting. In: Blackburn GL, Grant JP and Young VR (eds): Amino acids, metabolism and medical applicatlons. John Wright, PSG inc. Boston, p. 239-253, 1983.

10. Hoyumpa AM $J r$, Desmond PV, Avant GR, et al: Hepatic encephalopathy. Gastroenterology $76: 184-195,1974$.

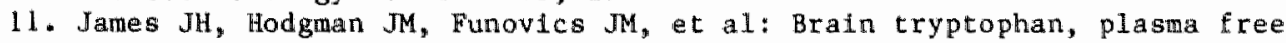
tryptophen and distribution of plasma neutral amino acids. Metabolism 25: $471-476,1976$.

12. James JH, Ziparo $V$, Jeppson $B$, et al: Hyperamonaemia, plasma amino acld imbalance, and blood-brain amino actd transport: a unified theory of porta-systemic encephalopathy. Lancet II, 772-775, 1979. 
13. Lee S, Chandler JG, Broelsch CE, et al: Current research review: porta systemic anastomosis in the rat. J Surg Res 17: 53-74, 1974.

14. Lee SH, Fisher B: Portacaval shunt in the rat. Surgery 50: 668-672, 1961 .

15. Lehmann EL, D'Abrera HJM: Nomparametrics: statistical methods based on ranks, Holden-Day Inc., San Francisco p. 1 and p. 123, 1975.

16. Munro HN, Fernstrom JD, Wurtman RJ: Insulin, plasma amino acid imbalance, and hepatic coma. Lancet I: $722-724,1975$.

17. Orlans E, Peppard J, Reynolds J, et al: Rapid active transport of immunoglobulin A from bload to bile. J Exp Med 147: 588-592, 1978.

18. Pector JC, Winand J, Dehaye JP, et al: Effects of portacaval shunt and transposition on fatty acid and cholesterol blosynthesis in rat 1 iver. Am J Physiol (Gastrointest Liver Physiol 2) 239: G83-G89, 1980.

19. Rossouw JE, Labadarios D, Vink AJ, et al: Liver glycogen after portacaval shunt in rats. Metabolism 27: 1067-1073, 1978.

20. Soeters PB, Weir G, Ebeld AM, et al: Insulln, glucagon, portal systemic shunting and hepatic fallure in the dog. J Surg Res 23: 183-188, 1977.

21. Unger RH: Glucagon and the insulin: glucagon ratio in diabetes and other catabolic 111 nesses. Diabetes 20: 834-838, 1971.

22. Vaerman JP, Lemaltre-Coelho I, Mc Sween RMM, et a1: Increased serum IgA levels in rats after portacaval shunt but not after portacaval transposition. Scand J Immunol 14: 131-136, 1981 . 
$-62-$

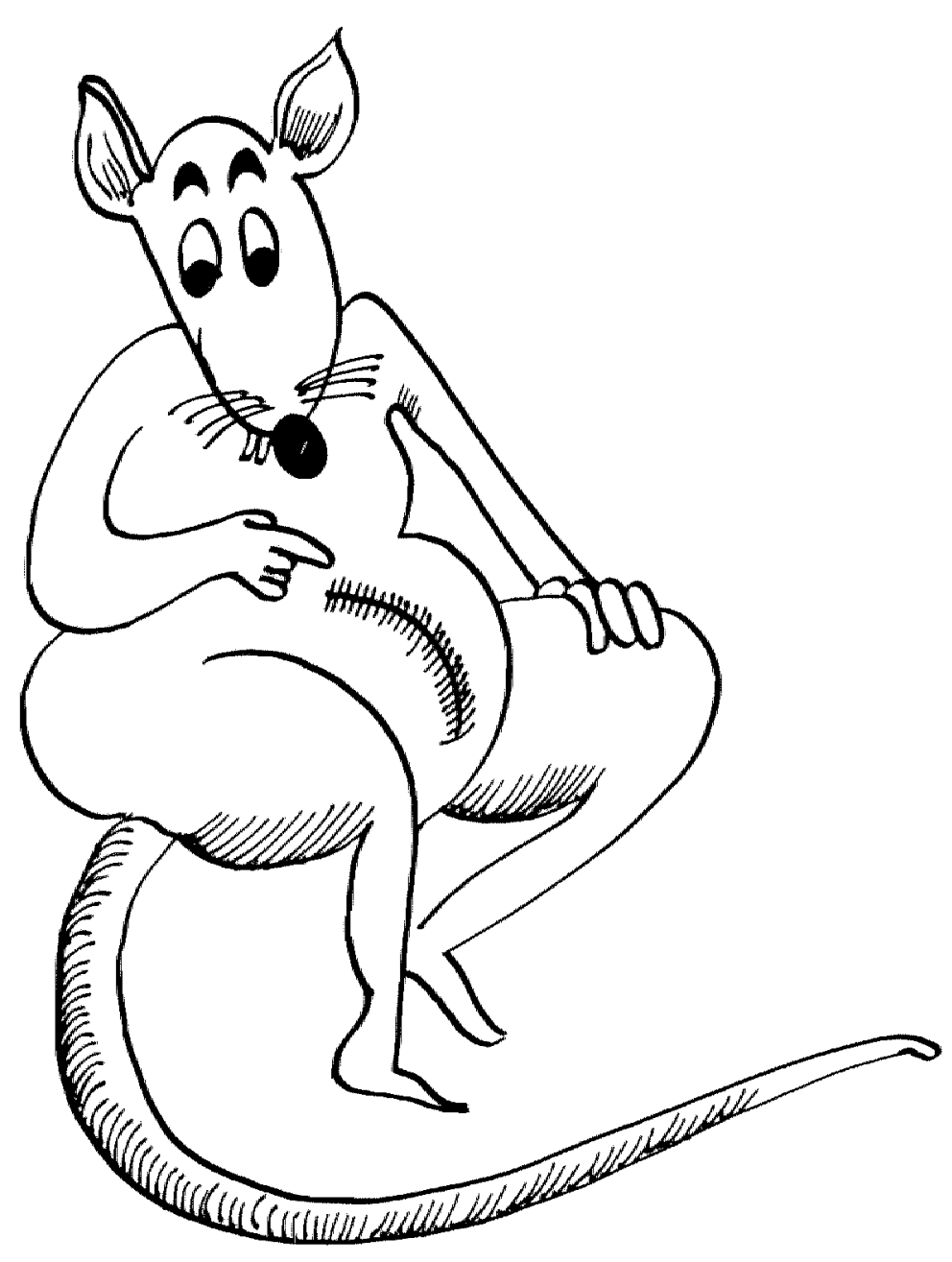


INFLUENCE OF PORTAL-SYSTEMIC SHUNTING ON LEUCINE MFTABOLISM IN MUSCLE AND ADIPOSE TISSUE OF FASTED AND FED RATS

Summary

Decreased levels of branched chaln amino acids (BCAA) in plasma have been frequently reported in patients and experimental anlmals with portalsystemic shunting (PSS) and hepatic insufficiency. To study the mechanism underlying this phenomenon, in vitro incubations were carried out with samples of muscle and adipose tissue from overnight fasted and fed portacaval shunt (PCS) operated rats, sham-operated (SO)- and non-operated controls. The incubation medium consisted of Krebs-Ringer bicarbonate buffer with ( $5 \mathrm{mM})$ or without glucose and coptalned physlological concentrations (0.1mM) of ${ }^{14} \mathrm{C}-(U)$-L-leucine or ${ }^{14} \mathrm{C}-(1)-\mathrm{L}-$ leucine (s.a. 0.25 $\mathrm{mCl} / \mathrm{mmo1}$ ). The incubation studies were done $2 \frac{1}{2}$ weeks after the operation. The results indicate that:

1. Two and alf weeks after the operations, significantly decreased levels of plasma BCAA occur in PCS rats as compared to control rats. At this time PCS rats weighed about $115 \%$ of their preoperative body weight and had significantly increased plasma insulin levels.

2. Sham-operated controls were not different from unoperated controls with respect to the parameters measured.

3. The addition of glucose increased the in witro catabolism of ${ }^{14} \mathrm{C}-(\mathrm{U})$ leucine by adipose tissue from normal and PCS operated rats. Both $\mathrm{CO}_{2}$-production and incorporation of leucine-derived carbon into fat were increased. Leucine metabolism by muscle was dafluenced by glucose only in the PCS group where more leucine was incorporated into muscle protein.

4. Feding did not significantly alter the $\mathbb{1 n}$ vitro $\mathrm{CO}_{2}$-production from $14 \mathrm{C}-(\mathrm{C})$-leucine by muscle, but $\mathrm{CO}_{2}$-production tended to be increased in the control groups and decreased in the PCS group. In adipose tissue, feeding changed in vitro the fate of a part of leucine-derlved carbon in both the control and PCS group by diminishing the amount released as $\mathrm{CO}_{2}$ and strongly augmenting the amount incorporated into fat.

5. PCS increased the catabolism of leucine in adipose tissue in vitro by increasing irreversible decarboxylation of the $\mathrm{C}-1$ atom of leucine. In muscle, decarboxylation of the $\mathrm{C}-1$ atom was not significantly altered. 
6. Afer PCS, the carbon skeleton of leucine that is left after decarboxylation of the $c-1$ atom, was in vitro catabolized to $C D_{2}$ to a lesser extent compared to controls, in both muscle and adipose tissue, and was incorporated into adipose tissue to a greater extent.

7. The carbon from all leuctne that is irreversibly decarboxylated in ad1pose tlssue from both sham-operated and PCS-operated rats, is incorporated into fat or metabollized to $\mathrm{CO}_{2}$ " This indicates that other reactions are negligible. In muscle, however, a significant part of the carbon atoms from the decarboxylated leucine, cannot be traced in protein or in the $\mathrm{CO}_{2}$ released.

After PCS, an increased catabolism of leucine can be measured in vitro in adipose tissue, independent of an overnight-fast. The role of adipose tissue in this increased catabolism after PCS seems to be extrenely important. These results ay explain the decreased plasma leucine levels encountered in patients and animals with PCS and hepatic insufficiency.

\section{Introduction}

In recent years, much attention has been paid to several aspects of branched chain amino acid (BCAA) metabolism. Clinically, a distorted neutral amino acid (NAA) pattern in plasma, including low BCAA levels, is assoclated with hepatic encephalopathy (11). BCAA might serve as alternative fuel in severe catabolic states $(2,9)$ and during exhaustive exercise (1). Furthermore tt has been suggested that leucine serves as a possible regulator of protein synthesis and turnover $(4,12,26)$.

Patients and experimental animals with compromised liver function and/or portal-systemic shunting (PSS) have decreased plasma BCAA levels and elevated plasma insulin levels (10). It has been postulated that these two phenomena are causally related (23). Decreased plasma BCAA levels have been suggested to result fron increased perlpheral uptake caused by hyperinsulinemia. The exact nature of this peripheral uptake has not been specifled. Less than $15 \%$ of the BCAA in the portal blood is extracted by the liver (36). Insignificant amounts of BCAA are degraded by the 1iver; these are probably the only andno aclds whose carbon skeletons can be completely broken down peripherally. In most 11terature reports, only muscle is considered to be capable of fulfilling this role. However, early and more recent work by Goodman $(14,15)$ suggests that adipose tissue nay also have a significant capacity to catabolize BCAA. Our investigation was performed to determine the influence of porta-caval shunting on the in vitro metabolism of leuctine-derived carbon by muscle and adipose tissue. Two studies are 
described. The first one, in which ${ }^{14} \mathrm{C}-(U)-\mathrm{L}-1$ eucine serwes as the substrate, deals with differences in in vitro leucine metabolism due to the post-absorptive or fed state of the rats, from which the tissues were derived, and due to the presence of glucose ( $5 \mathrm{mM}$ ) in the incubation mediun. In the second study described, elther ${ }^{14} \mathrm{C}-(U)-L-$ leucine or ${ }^{14} \mathrm{C}-(1)-L_{-}-$ -leucine served, in separace incubation flasks, as the substrate for tissues derived from the same rats (fed state only). This allows estination of what happens with the rest of the carbon skeleton of leucine after decarboxylation.

Materials and methods

Male Sprague-Dawley rats $(200-240 \mathrm{~g})$ were used. They were housed under standard laboratory conditions wth a fixed dark-light schedule (12 hrs dark; 12 hrs light) and were fed regular laboratory rat chow and water ad 1ibitum. PCS operations were performed under ether anesthesia employing a "button" technique (13). The PCS operation took about 25 minutes. Mortality was 10-15\% and death occurred mostly within 24 hours after operation. The sham-operated rats underwent laparotomy and portal vein occlusion for 10 minutes .

Bload was drawn under ether anesthesia by ocular puncture, before operation and before sacrifice in the study.

Plasma imsulin (IRI) was determined with a comercially avallable radioimmunoassay kit (Wellcome, Beckenham, England) with human standards and antisera.

Plasma amino acids were determined in plasma that was deproteinized with sulfosalicylic acid $(5 \% \mathrm{w} / \mathrm{v})$ and filtered through 0.22 um pore filters. Samples were analyzed on a LKB 4400 amino actd analyzer running a phystological program with $5 \mathrm{Li}^{+}$-buffers according to Dilley and Rocek (8).

Tissue DNA content was determined in muscle according to Burton (3) and in adipose tissue according to Rafael and Vsiansky (32).

\section{Incubation procedure}

The animals were killed by cervical dislocation; the epldidymal fat pads and the diaphragm were removed quickly. Tissue samples of $30-40 \mathrm{mg}$ (diaphragm or epididymal fat pad) were placed in sillconized 25 mi Erlenmeyer 
flasks containing $5 \mathrm{ml}$ carbogenated Krebs-RInger bicarbonate buffer pH 7.4 and placed in a shaker-bath. After 15 minutes pre-incubation, ${ }^{14} \mathrm{C}-(\mathrm{U})-\mathrm{L}-$ leucine $(0.25 \mathrm{mCl} /$ mol $)$ or ${ }^{14} \mathrm{C}-(1)-\mathrm{L}$-leucine $(0.25 \mathrm{mCl} / \mathrm{mmol})$ was added to a concentration of $0.1 \mathrm{mM} .{ }^{14} \mathrm{C}-(0)$-leuclne $(340 \mathrm{mCl} / \mathrm{mmol})$ and ${ }^{14} \mathrm{C}-(1)$-leucine (55 mCl/mmol) were purchased from New England Nuclear Carp. (Boston, Mass.). The incubations were carried out for 90 min at $38.5^{\circ} \mathrm{C}$ in a shaker-bath at 60 cycles per minute. From each rat, tissue samples were Incubated in triplicate for measurement of labeled $\mathrm{CO}_{2}$ produced by muscle and adipose tissue, and in duplicate for deternination of incorporation of leuctne-derived carbon into protein by muscle and into fat by adipose t1ssue. $\mathrm{CO}_{2}$-release and incorporation of leuclne-derived carbon into muscle tissue were determined essentially according to odessey and Goldberg (25) with some minor modifications in the chemicals used, including the tissue solublitzer Soluene ${ }^{R}-350(0.5$ N Quaternary Ammonium Hydroxide in Toluene; Packard-Becker BV, Chemical Operations, Groningen, The Netherlands). A major modification was the use of separate incubation flasks for the determination of $\mathrm{CO}_{2}$-release and incorporation of leucine-derived carbon into muscle protein and into fat in adipose tissue, to avold the loss of $\mathrm{CO}_{2}$ released. The incorporation of ${ }^{14} \mathrm{C}-(\mathrm{U})$-Leucine-derived carbon into fat in adipose tissue was determined according to Goodman (14).

\section{$\underline{\text { Results }}$}

\section{Body we1ght.}

PCS rats 10st $10 \%$ of thell body welght postoperatively $(p .0$.$) , but had$ regalned their preoperative weight within two weeks. Starting from their minimum welght $(3-7$ days p.o.), they showed slmilar growth rates compared with sham-operated rats (SO rats) and unoperated control rats. Rats that falled to gain welght p.o., or had not reached their initlal body welght 21 weeks p*o., were excluded from the study. At the time of the experiments (2t weeks p.o.), PCS rats, so rats and control rats, used in the first study described, weighed about $115 \%, 140 \%$ and $140 \%$, respectively, of their initial weights. Rats used in the incubation study in which ${ }^{14} \mathrm{C}-(1)$-leucine was compared with ${ }^{14} \mathrm{C}-(\mathrm{U})$-leucine, weighed about $115 \%$ and $135 \%$ respectively for PCS and So rats. 


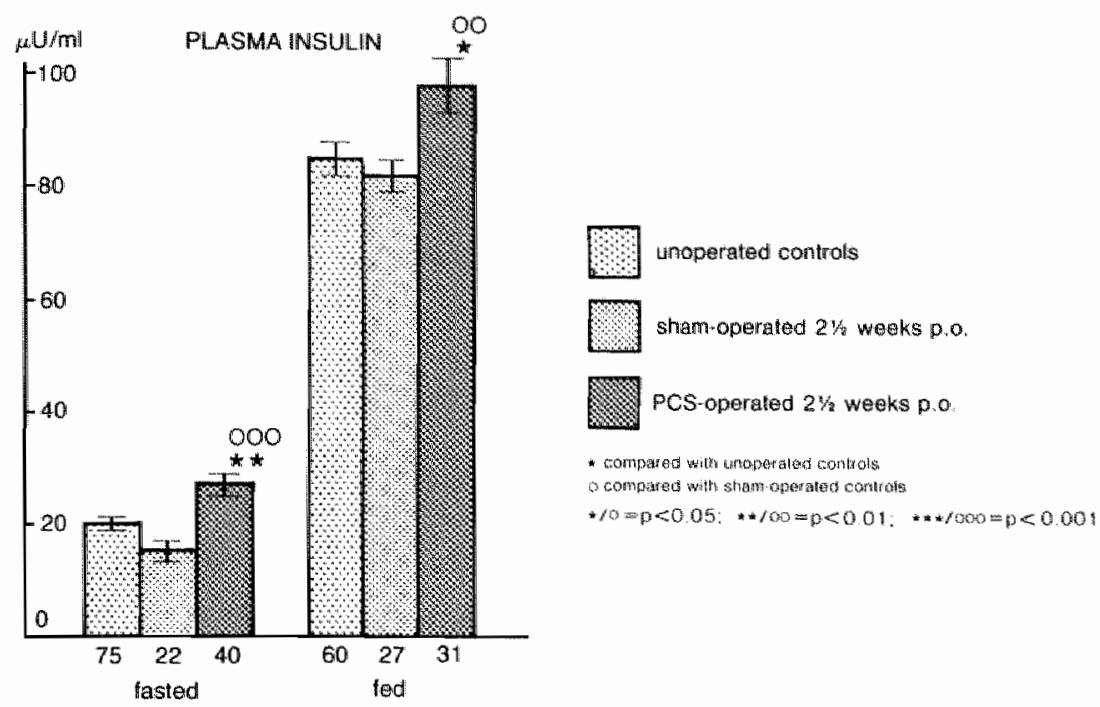

Figure 1

Plasma immunoreactive insulin (IRI) in fasted and fed unoperated, sham-operated and PCS-operated male Sprague-Dawley rats (mean \pm sem).

PLASMA BRANCHED CHAIN AMINO ACIDS

PLASFALEUCARIE
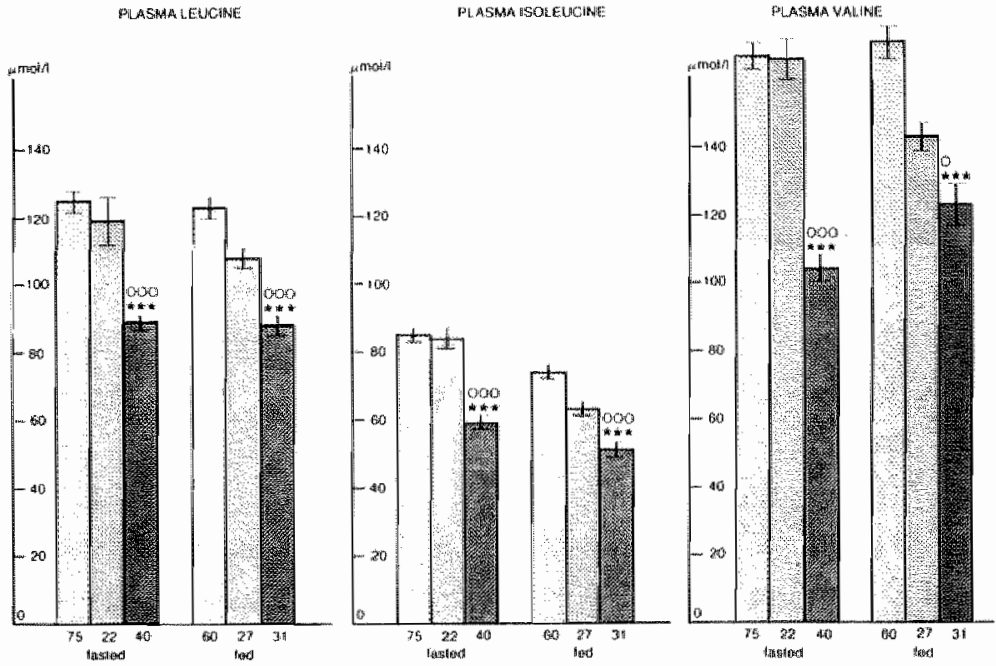

ㄱ.

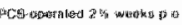

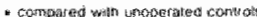

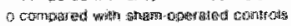

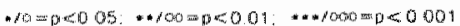

Figure 2

Plasma branched-chain amino acids in fasted and fed unoperated, shamoperated and PCS-operated male Sprague-Dawley rats (mean I sem). 
Insulin (IRT)

Fasted (14-18 hrs) and fed values of IRI in the plasma of PCS rats, SO rats and control rats were derlved from separate groups of rats (fig. 1). In the fasted state, plasma IRI levels were lncreased in the PCS group $(30-50 \%)$ as compared to both control groups. In the fed state, plasma IRI levels $\mathbb{i n}$ the PCS group were also increased by about the same absolute amount.

\section{Amino actd levels}

In the PCS group, plasma BCAA-levels $2 \frac{1}{2}$ weeks p.o. (fig. 2) were consistent1y decreased to a $70 \%$ level as compared to the 50 group and the control group. This result was obtained for both fasted and fed rats.

Incubations with ${ }^{14} \mathrm{C}-(\mathrm{U})$-L-leucine; Influence of feeding; influence of glucose in the incubation medium

The leucine-metabollzing activity in diaphragm and epldidymal adipose tissue was measured in the presence of a physiological concentration of ${ }^{14} \mathrm{C}-(\mathrm{U})$-L-leucine $(0.1 \mathrm{mM})$ with and without glucose and was expressed in pmol/ $\mu$ g DNA.90 min., calculated from the speciflc activity of leucine in the incubation medium. The measured parameters, $\mathrm{CO}_{2}$-production by muscle and adpose tisue, Incorporation into muscle protein and incorporation into fat, were linear with time to at ieast 120 minutes. A correction for tissue DNA-content was applied to correct for different numbers of cells in the tissues used, due to differences in cell size between PCS- and control rat-derived tissue.

\section{Diaphragm}

The anount of leucime-carbon derived $\mathrm{CO}_{2}$, produced in vitro by diaphragin from $14 \mathrm{C}-(\mathrm{U})$-1euclne, was not significantly altered by PCS (except in the fed state without glucose; $p<0.05)$, nor by the presence of glucose in the Incubation medium ( $f$ ig. 3), when results are expressed per $\mu \mathrm{g}$ DNA. Feeding did seem to increase $\mathrm{CO}_{2}$-production from ${ }^{14} \mathrm{C}-(\mathrm{U})$-leucine in diaphragm from unoperated and sham-operated rats (no significance reached), while this $\mathrm{CO}_{2}$ production in diaphragm from PCS-operated rats tended to be 
slightly decreased. No significant differences were noted between unoperated control rats and so rats. When glucose was present in the incubation medium, the incorporation of ${ }^{14} \mathrm{C}$-(U)-leucine derived carbon into proteln in diaphragm, also shown in $\mathbf{f i g}$. 3, was increased by PCS in the fed state ( $p<$ $0.05)$. Feeding or the presence of glucose in the incubation medium did not significantly alter the incorporation of ${ }^{14} \mathrm{C}-(\mathrm{U})$-leucine into muscle protein.

\section{Epididymal adipose tissue}

$\mathrm{CO}_{2}$-production from ${ }^{14} \mathrm{C}-(\mathbb{U})$-leucine by adipose tissue was not significantly affected by PCS under all measured conditions (fig. $3 \mathrm{a}, 3 \mathrm{~b}, 3 \mathrm{c}$ and 3d). The presence of glucose in the incubation medium increased the $\mathrm{CO}_{2}$ production by adlpose tissue in all three groups ranging between $34-104 \%$ $(0.05<\mathrm{p}<0.005)$. In the presence of glucose (fig. $3 \mathrm{a}$ and $3 \mathrm{~b}$ ), feeding decreased $\mathrm{CO}_{2}$ production in all groups between 19-34\% and was significant in the So group $(\mathrm{p}<0.001)$ and PCS operated group $(\mathrm{p}<0.01)$.

When glucose was added to the incubation medium, a three-fold increase was observed in the incorporation of ${ }^{14} \mathrm{C}$-(U)-leucine derived carbon into adipose tissue in the PCS-group (fig. $3 a$ and $3 \mathrm{~b} ; \mathrm{p}<0.001$ ). In the absence of glucose, a decrease was noted in the fasted state, when control groups were compared wth the PCS group $(p<0.01)$, while in the fed state a two-fold increased incorporation in the PCS group was detected ( $p<0.05$ ). Feeding increased incorporation of leucine-derived carbon in the presence of glucose in all groups ( $\mathrm{p}<0.005$ ). Without glucose, feeding increased leucine-carbon incorporation only in the PCS group ( $p<0.001$ ), and even decreased the incorporation in the control groups $(p<0.005)$. Glucose in the Incubation medium strongly enhanced the level of Incorporation of ${ }^{14} \mathrm{C}-(\mathrm{U})-1$ eucine-derived carbon in a 11 groups $(\mathrm{p}<0.005)$.

Incubations with ${ }^{14} \mathrm{C}-(U)-L-1$ eucine vs ${ }^{14} \mathrm{C}-(1)-L-1$ euclne; Irreversible decarboxylated leucine and degree of oxidation of the leucine carbon skeleton

These incubations were carriled out in the presence of glucose (5mM) and with tissues from fed rats. ${ }^{14} \mathrm{C}-(U)-\mathrm{L}-1$ euclne and ${ }^{14} \mathrm{C}-(1)-\mathrm{L}-1$ leucine were added to a physiological concentration $(0.1 \mathrm{mM})$ and had the same spectfic activity $(0.25 \mathrm{mCl} / \mathrm{mmol})$. The consequence of this is a sixfold 


\section{LEUCINE METABOLISM}
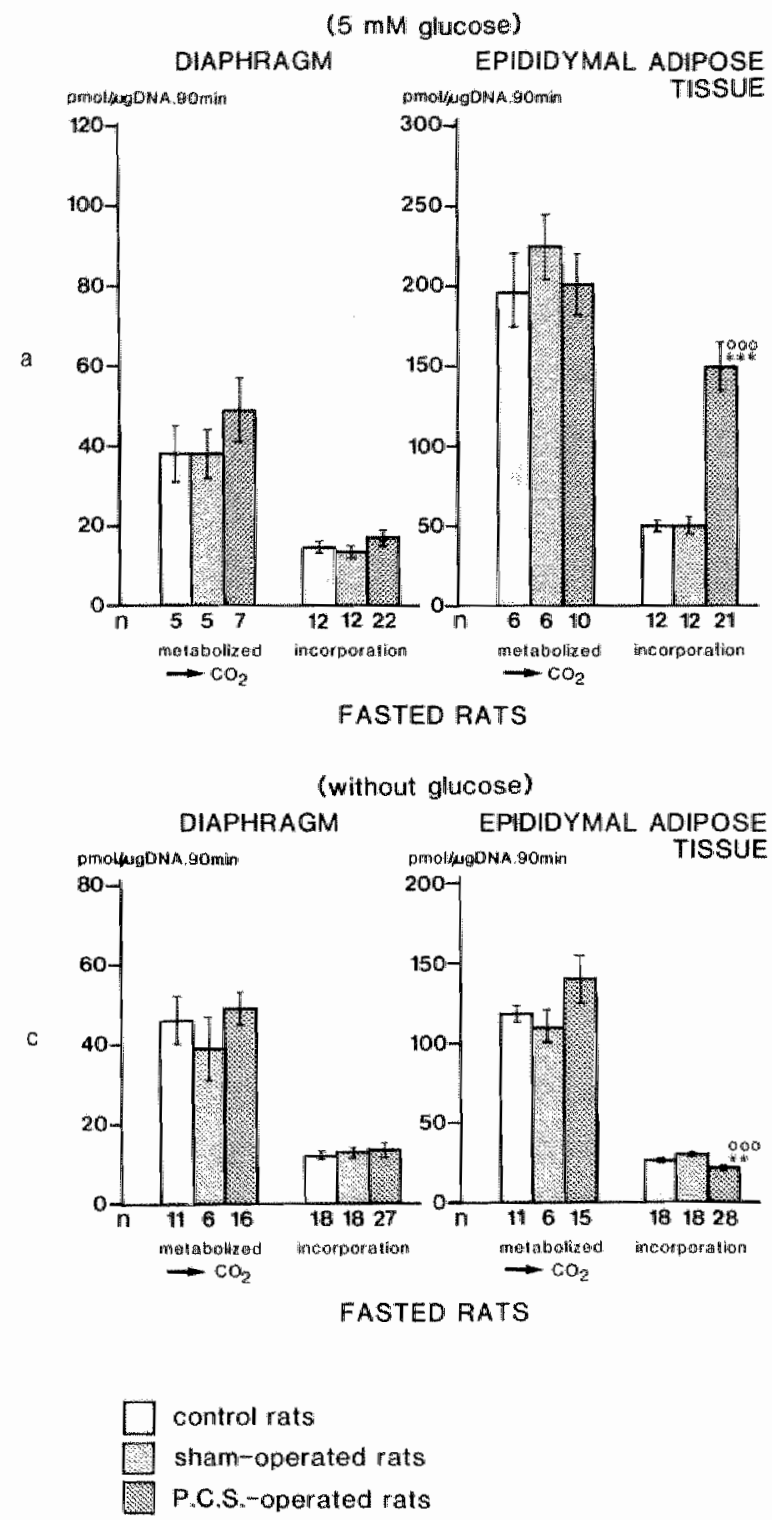

Figure 3

Leucine-metabolism in vitro in diaphragm and epididymal adipose tissue derlved from fasted ( $a$ and $c$ ) and fed ( $b$ and $d$ ) unoperated, sham-operated (2t weeks p.o.) and PCS-operated ( 2 t weeks p.o.) rats, measured in the presence of $0.1 \mathrm{mM}{ }^{14} \mathrm{C}-(\mathrm{U})-\mathrm{L}-$ leucine with ( $\mathrm{a}$ and $\mathrm{b}$ ) and without $(\mathrm{c}$ and $\mathrm{d}$ ) $5 \mathrm{mM} g$ lucose in the incubation medium (mean \pm sen). Detalls are described in Materials and Methods. 


\section{LEUCINE METABOLISM}

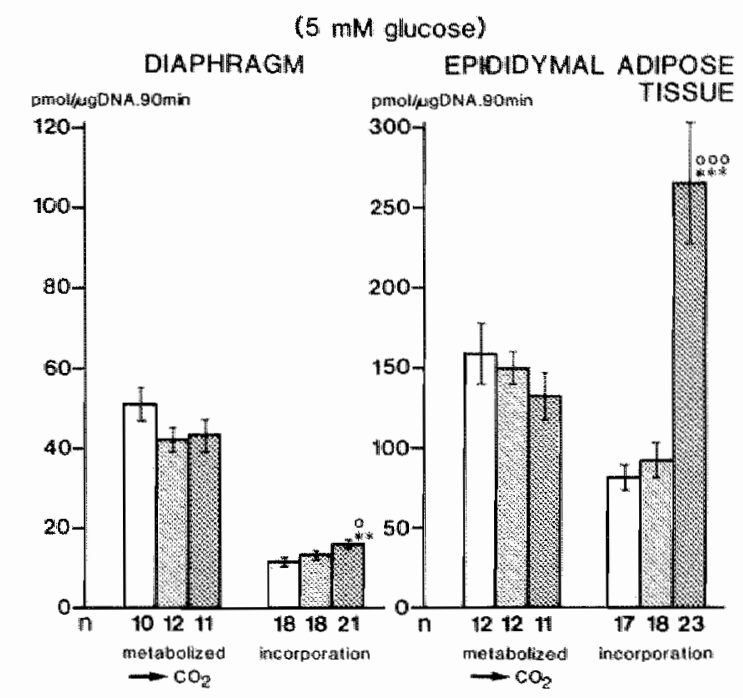

b

\section{FED RATS}

(without glucose)

\section{DIAPHRAGM}

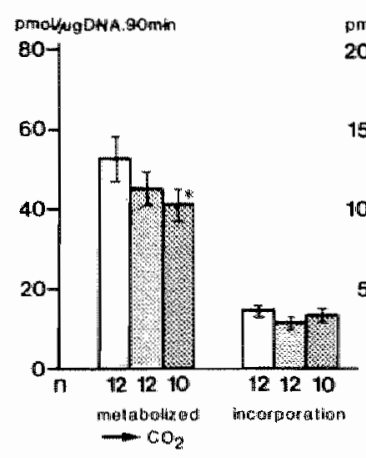

EPIDIDYMAL ADIPOSE

pmolisglona.90min TISSUE

$200-1$

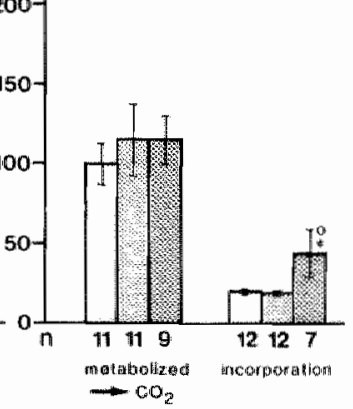

d

FED RATS

* comperad with uncperavad controls

a compored with sihammoperate di controls

Ho $=0<0.05 ; * 100=0<0.01, * 01000=0<0.001$

Leucine-derived carbon released as $\mathrm{CO}_{2}$ by diaphragm, incorporation of leucine-derived carbon into muscle protein, leucine-derived carbon released as $\mathrm{CO}_{2}$ by epldidymal adipose tissue and incorporation of leuclnederived carbon into fat in adipose tissue are plotted separately (from left to right, respectively). Results are expressed in prol/ $\mu$ g DNA.90 min. 


\section{LEUCINE METABOLISM}

${ }^{1 / 6} \mathrm{C}-(1)-L-L E U$ vS. ${ }^{14} \mathrm{C}-(\mathrm{U})-\mathrm{L}-\mathrm{LEU}$
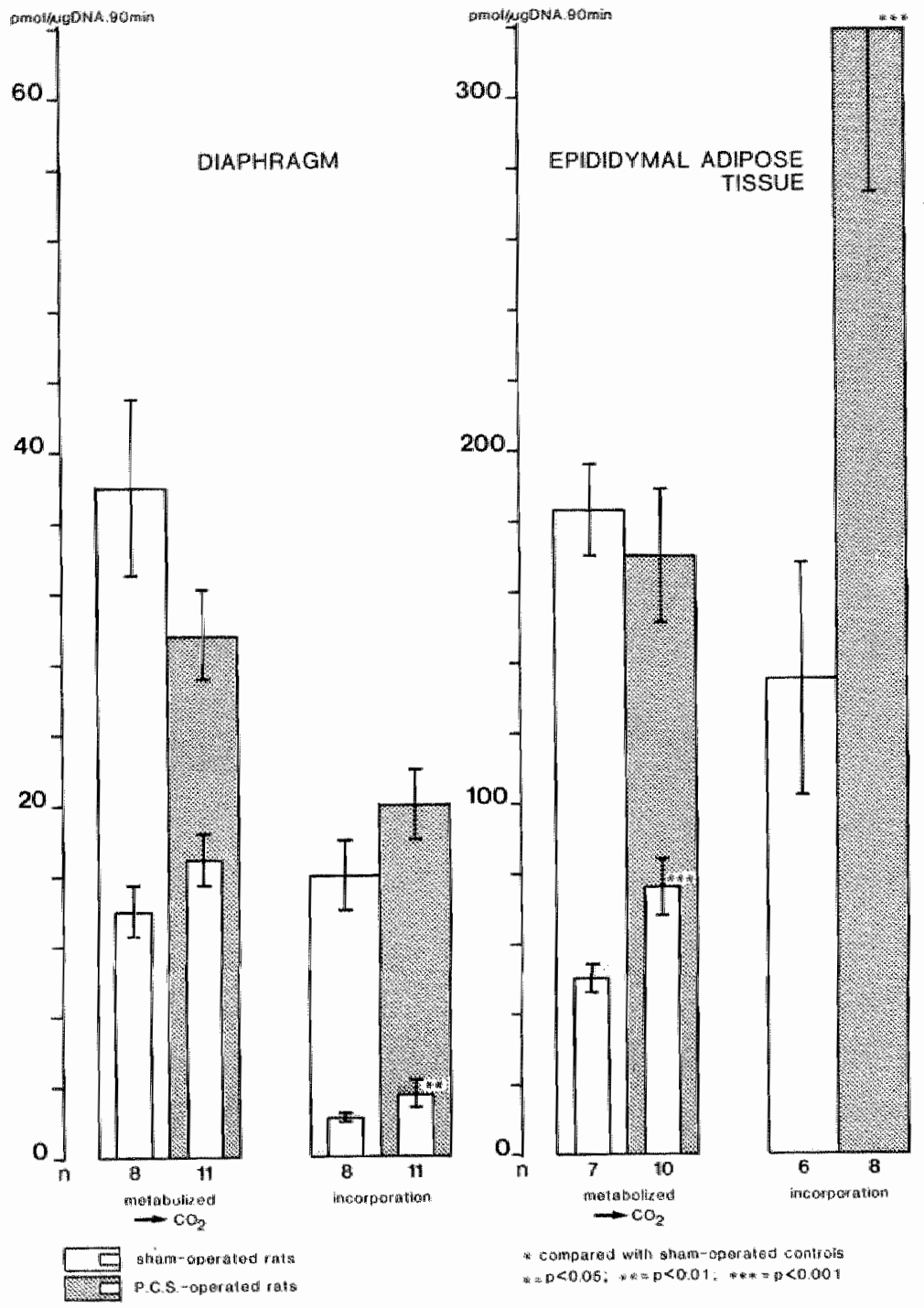

Figure 4

Leucine-metabolism in vitro in diaphragm and epldidymal adipose tissue derived fr

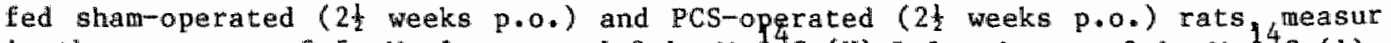
in the presence of $5 \mathrm{mM}$ glucose and $0.1 \mathrm{mM}{ }^{14} \mathrm{C}-(U)-\mathrm{L}-1$ eucine or $0.1 \mathrm{mM}{ }^{14} \mathrm{C}-(1)$ leucine in the incubation mediun (mean + sem). Details are described in Materia and Methods. Leucine-derlved carbon released as $\mathrm{CO}_{2}$ by diaphragm, incorporation leucine-derived carbon into muscle protein, leucine-derived carbon released as $C$ by epldidymal adipose tissue and incorporation of leucine-derived carbon into $f$ in adipose tissue are plotted separately (from left to right, respectively Results are expressed in pmol/ $\mu \mathrm{g}$ DMA.90 min. Note that the ordinates ha different scales for diaphragm and adipose tissue (consequence of difference tissue pNA content). The inner bars represent results derived from incubations which ${ }^{14} \mathrm{C}-(1)$-leuclne served as substrate. 
higher spectfic activity for the $c-1$ carbon atom in ${ }^{14} \mathrm{C}-(1)$-labeled leucine compared to ${ }^{14} \mathrm{C}-(\mathrm{U})$-labeled leucine. Therefore, the results presented in fig. 4 were corrected for this difference to be able to compare the proportion of irreversibly decarboxylated (C-1-atom) leucine, representing the first step of leucine degradation, to the amount of levcine derlved carbon originating from the rest of the leucime molecule. The results are expressed per $\mu g$ DNA in the tissue.

\section{Diaphragm}

No significant differences were measured in $\mathrm{CO}_{2}$-production from elther ${ }^{14} \mathrm{C}-(1)$ - or ${ }^{14} \mathrm{C}-(v)$-labeled leucine between tissues derived from so-rats and PCS rats, but there is a tendency for $\mathrm{CO}_{2}$-production from ${ }^{14} \mathrm{C}-(1)-$ leucine to be increased and from ${ }^{14} \mathrm{C}-(U)$-leucine to be decreased $(\mathrm{p}<0.1)$ by PCS. A small increase in incorporation of leucine into muscle protein was detected. This increase was significant when ${ }^{14} \mathrm{C}-(1)$-1eucine was used as substrate $(\mathrm{p}<0.01)$, while $\mathrm{p}$ reached 0.1 when ${ }^{14} \mathrm{C}-(\mathrm{U})$-1euclne was adided. The ratio of ${ }^{14} \mathrm{C}$-labe1 incorporated into protein in the So-group and PCS operated group, starting from ${ }^{14} \mathrm{C}-(1)$ - and from ${ }^{14} \mathrm{C}-(\mathrm{U})$-leucine, is exactly 1 when no correction is made for the 6 times higher specific activity of the $\mathrm{C}-1-$ carbon atom in ${ }^{14} \mathrm{C}-(1)$-leucine. This Indicates that leucine is incorporated as "whole" 1euctme.

\section{Adipose tissue}

$\mathrm{CO}_{2}$-production from ${ }^{14} \mathrm{C}$ - (U)-leucine by adipose tissue was not altered by $\mathrm{PCS}$, in contrast to the $\mathrm{CO}_{2}$ production from ${ }^{14} \mathrm{C}-(1)$-leuclne, which was significantly increased $(\mathrm{p}<0.0005)$. Incorporation of ${ }^{14} \mathrm{C}-(\mathrm{U})$-1eucinederived carbon into fat of adipose tissue was increased two-fold in the pCS group. As expected, no ${ }^{14} \mathrm{C}-(1)$-leucline derlved carbon could be detected in fat.

\section{Discussion}

These results indicate that PCS increases the catabolism of leuctne in adipose tissue in vitro by Increasing irreversible decarboxylation of the C-1 atom of leucine and by lncreasing the incorporation of leucine degradation products (mainly acety1-CoA) Inta fat. This increased degradation of leucine by adipose tissue may contribute to the decreased circulating 
leucine levels in plasma after PCS. It is peculiar that these studies seem to Indicate that degradation products of leucine, which is catabolized to a greater extent after PCS, serve as precursors for fatty acid symthesis. Especlally in PCS rats, which norma1ly have less muscle mass and less storage fat than normal rats, an increased irreversible decarboxylation of leucine and corresponding fatty acld synthesis in particular, seems to conflict with the desirability to retain or maintain positive nitrogen balance in these rats and wh the special anabolic properties ascribed to leucine, such as stimulation of protein synthesis and regulation of protein turnover.

This study also indicates that in vitro after PCS, the carbon-skeleton of leuclne that is left after decarboxylation of the $c-1$ atom, is catabolized to $\mathrm{CO}_{2}$ to a lesser extent. The recorded values for $\mathrm{CO}_{2}$-production and incorporation into fat after incubation with ${ }^{14} \mathrm{C}-(\mathrm{U})$-leucine account for complete degradation of the decarboxylated leucine as estinated in incubatolons with ${ }^{14} \mathrm{C}-(1)$-leucine, both $1 \mathrm{n}$ control and in PCS rats. However, in PCS rats, the remaining carbon-skeleton after decarboxylation of leucine, is degraded to $\mathrm{CO}_{2}$ to a lesser extent and incorporated into fatty actds to a greater extent.

Careful definition of the PCS rat model showed that, in our institute, PCS rats lost some speciflc metabolic characteristics of PCS $3 \frac{1}{2}-4$ weeks after the operation ( 7 ), mainly due to the development of collateral blood vessels between the portal clrculation and the liver. Therefore, experiments were carried out $2 \frac{1}{2}$ weeks $p .0$. In order to eliminate the possibility that non-spectflc metabolic effects of the operation would influence the resultw, sham-operated controls were included in the first study described, in addition to non-operated controls. Because no differences were observed between sham-operated controls and nom-operated controls, the non-operated controls were onitted in the second study. The PCS rats employed in this study lost welght 3-4 days after the operation and from the fourth day exhibited normal growth rates and the metabolic characteristics that are thought to be specific for PCS including changes in plasma AA pattern and pancreatic hormone levels. Of these, decreased pliasma BCAA levels and hyperinsulinemia are relevant for this study. In many studies, pcs rats falled to gain weight in the weeks following the operation $(5,30,34)$ and 
were wirtually malnourished at the time of the experiments, making an exact incerpretation of the data difficult.

In our experiments, the PCS-rats were slightly leaner due to a reduced food intake in the first days after the operation. Leaner rats have less adipose tissue and smaller fat cells, containing less fat and relatively more proteln. Expressing the biochemical metabolic data of the incubation studies per unit wet tissue weight, implies that different numbers af cells are compared between the controls and the PCS-group. We assumed that the total number of cells in a rat does not change within $2 \frac{1}{2}$ weeks after the PCS operation, compared with a sham operation, and chose tissue DNA-content to correct for different numbers of cells. All recorded values in the studies described were corrected for individual tissue DNA content. However, there was also a considerable difference in DNA content between diaphragms from PCS-rats and control rats, indicating a difference in myofibrillar protein content per cell. A difference in (de)hydration of diaphragms from control rats and PCS operated rats was excluded by t1ssuenitrogen determinations (chemiluminescence method; ref. 38). Mean values for tissue DNA content in diaphragm and adipose tissue of PCS- and so rats are listed in table $\mathrm{I}$. This correction for tissue DNA content influenced the interpretation of our data.

TISSUE DNA CONTENT ( $\mu \mathrm{g}$ DNA/mg wet weight)

\begin{tabular}{l|c|c}
\hline & Adipase tissue & Muscle \\
\hline $\begin{array}{l}\text { Sham-operated and } \\
\text { non operated }\end{array}$ & $0.31 \pm 0.04$ & $1.69 \pm 0.11$ \\
PCS-operated & $0.45 \pm 0.07$ & $2.33 \pm 0.31$ \\
\hline
\end{tabular}

Table I

Tissue DNA content in diaphragm and epididymal adipose tissue from control rats (unoperated and SO-operated) and PCS operated rats; mean $\pm S D(n=50)$. 
Our results from the tissue Incubations with $0.1 \mathrm{mM}^{14} \mathrm{C}-(\mathrm{U})-\mathrm{L}-\mathrm{leucine}$ and with ${ }^{\mathbb{4}} \mathrm{C}-(1)-\mathrm{L}-\mathrm{let}$ ine $(\mathrm{fig}$. 4) dewonstrate that PCS increased the amount of leucline metabolized in vitro by adipose tissue. The increased $\mathrm{CO}_{2}$-production from the $\mathrm{C}-1$ labeled substrate represents increased irreversible decarboxylation of the $\mathrm{C}-1$ atom of leucine. In contrast, $\mathrm{CO}_{2}-$ production from ${ }^{14} \mathrm{C}$-(U)-leucine in the PCS group was not different from the control ( $\left.\mathrm{SO}^{-}\right)$group. The difference in $\mathrm{CO}_{2}$-production between ${ }^{14} \mathrm{C}-(\mathrm{U})$ - and $14 \mathrm{C}-(1)-1$ euctne is the result of further metabolism of the Leucine-carbon skeleton after decarboxylation of the $c-1$ atom, and may be difficult to interpret because of the existence of several potential routes of further metabolism of leucine degradation products; different carbon atoms may be involved differenty in further metabolism. The decreased ratio between $\mathrm{CO}_{2}$-production from ${ }^{14} \mathrm{C}-(\mathrm{U})$ - and ${ }^{14} \mathrm{C}-(\mathrm{l})$ leucine in adipose tissue in the PCS group, as compared to the so-group, reflects a proportionally less complete catabolism of leuclne (to $\left.\mathrm{CO}_{2}\right)$. However, all carbon atoms derived from leucine that is Irreversibly decarboxylated in vitro in adipose tissue of both PCS rats and control rats, are incorporated in fat or catabolized to $\mathrm{CO}_{2}$ * Other reactions seem to be quantitatively unimportant in this respect. This is 111 ustrated by the fact that, in both groups, the sum of the amount of leucine-carbon degraded to $\mathrm{CO}_{2}$ and the amount stored in fat during incubation with ${ }^{14} \mathrm{C}-(\mathrm{U})$-leucine, approximately equals six times the $\mathrm{CO}_{2}$ produced during incubation with ${ }^{14} \mathrm{C}-(1)$-leucine (PCS-group: 488 vs $6 \mathrm{x}$ 76; SO-group: 318 vs $6 \times 50$ ). The possibility that different intracellular pools of acetyl-CoA in tissues from PCS rats and control rats have influenced the results, seems to be only of theoretical importance. The increased Incorparation leucine-derived carbon into fat after PCS, implies that increased fatty acid turnover must exist in PCS rats because PCS rats have less fat than controls.

In addition to the differences detected in leucine metabolism by adipose elssue, a small increase in incorporation of leucine-carbon into muscle protein was measured in vitro in diaphragm after PCS. The ratio of leucine-derived ${ }^{14} \mathrm{C}$ from ${ }^{14} \mathrm{C}-(\mathrm{U})$ - and ${ }^{14} \mathrm{C}-(1)$-leucine in muscle protein was six to one. This demonstrates, as expected, that "whole" leucine molecules are incorporated into muscle protein. Leucine incorporation into muscle proteln, increased by PCS, can be reutilized after proteolysis for new protein synthesis. As in PCS rats no increased growth-rate or muscle hyper- 
trophy has been observed, the in vitro result in muscle suggests an increased pratein-turnower rate in vivo. This finding is supported by an increased 3-methyl-histidine excretion in the urine of PCS rats. We recorded in six PCS-operated rats (about $240 \mathrm{~g}$ ) a 3-twethylhistidine excretion in the urine of $1.44 \pm 0.10 \mu$ mol/24 hrs, while six controls (circa $300 \mathrm{~g}$ ) excreced $1.18 \pm 0.18 \mu \mathrm{mol} / 24 \mathrm{hrs}$. While 3-methylhistidine excretion does not exclusively indicate skeletal muscle protein degradation (22), our finding of increased incorporation of leucine into diaphragm in vitro after PCS strongly suggests that the increased 3 -methylhistidine excretion originates from skeletal muscle rather than from the gut. In contrast to the increased incorporation of leucine into muscle proteln from PCS-rats, the increased decarboxylation of leucine in adipose tissue means a definitive loss as leucine, because after deamination and decarboxylation, the rest of the molecule is metabolised to acety1-CoA and acetoacetic acid from which leucine cannot be resynthesized.

In vitro $\mathrm{CO}_{2}$-production, by diaphragm, from ${ }^{14} \mathrm{C}-(1)$-leucine tended to be increased in the PCS group, while, from ${ }^{14} \mathrm{C}-(U)$-leuclne, it strongly tended to be decreased after PCS $(\mathrm{P}<0.1)$. Therefore, irreversible degradation (decarboxylation) may have been slightly enhanced after PCS, but the rest of the leucine-molecule is less completely degraded to $\mathrm{CO}_{2}$ in muscle. This pleads agalnst a muscle energy deficit as the driving force for increased BCAA catabolism.

Incorporation of label into fatty acids in muscle, and into protein in adipose tissue were not measured in these experimentw. It has been reported that these quantities are negliglble ( 25$)$.

The presence of glucose in the incubation medium did not lnfluence $\mathrm{CO}_{2}$-production and incorporation into protein in diaphragm of normal rats, but did influence $\mathrm{CO}_{2}$-production and incorporation of label into fat, in adipose tissue (fig. 3). This indicates that different mechantsms are operative. The exact mechanlsm of action of glucose in the metabolism of leucine in adipose tissue is not known. The integrity of the cell or some cellular organelle may be concerned in the expresston of this effect. The difference may be partially explained by the formation of glucose-derived glycerol which serves as the "backbone" for triglyceride synthesls. "The data measured in the presence of glucose are, of course, more relevant to the in vivo situation. 
The increase of the peripheral leucine metabolism after PCS in adipose tiscue was observed in tissues derived from both fasted and fed rats (fig. 3). Consequently, this appeared to be no effect of fasting or feeding, accompanied by short-term changes in clrculating leuclne or pancreatic hormones. However, feeding changed the fate of a part of leuclne-derlved carbon in adipose tissue by decreasing $\mathrm{CO}_{2}$-release and increasing the incorporation Into fatty actds. This effect was most pronounced when glucose was present in the incubation medium and occurred in both normal and PCS rats. Pluctuations in clrculating levels of glucose, amino acids and insulin may exert short-term control as suggested by studies of Goodman and Frlck $(14,16)$. Using tissue slices and cell-free preparations, they have shown in vitro that some aspects of the processing of leucine by adipose tissue from normal rats, can be influenced by adding these components to the incubation medium. This has been suggested to be due to activation of w-keto-isocaprolc acid-dehydrogenase ( $a-K I C A-D H)$, the rate-limiting enzyue in the catabollc pathway of leucine in most tissues, but not in 11ver. They have also shown that these tissues retain in vitro some of their characteristics with regard to the catabolism of leucine, which has been suggested to be due to the total amount of a-KICA-DH (active and inactive), induced by in vivo exposure of the tissues to insulin, for instance in tissues from diabetic rats and from rats fed diets containing variable amounts of proteln (16). The increased in vitro leucine metabolism in tissues from PCS-rats must result from long-term regulation of the leucine degradative pathway because it persists after overnight fasting. As mentioned, evidence is accumulating that insulin is involved in determining in vitro the rate of breakdown of leucine in adipose tissue. Hyperinsulinemia was consistent1y present in our PCS rats both in the fasted and fed state, although the percentage increase in the fed state was small (fig. 2). The fact that overnight-fasting hardly influences the alterations in leucine metabolism In adipose tissue (and in muscle) after PCS, indicates that the time needed to express the effect is days or weeks rather than hours. For these reasons, it is very $11 k$ lity that the increased in vicro leucine metabolism in adlpose tissue from PCS rats is caused by long lasting hyperinsulinism due to portal-systemic shunting. Both increased decarboxylation of leucine mediated by a-KICA-DH, and Increased facty acid synthesis may result from hyperinsulinism. The increased muscle proteln synthesis after PCS may also 
be the result of prevaliing hyperinsulinism. In muscle, a-KICA-DH seems not to be regulated by insulin, but by ATP, redox state and muscle work $(24,29)$. In addition, insulin is reported to stimulate uptake of BCAA in muscle $(31,37)$ but the possible influence has not been measured in these experiments.

The cause for the hyperinsulinisr in portal systemic-shunting and patients with chronic liver fallure is still subject to controversy. A causal relationship between plasma insulin levels and plasma BCAA levels has often been suggested, but has yet to be prowen.

The data obtained with adipose tissue suggest an extremely well fed state in PCS rats compared to controls, despite equal or even slightly decreased food intake. Even after overnight fasting, fatty actd synthesis from leucine-derived carbon (via acetyl-CoA) in pCS rats is increased compared to fed control rats ( $f i g$. 3). If this is indeed an insulin effect, it may be concluded that insulin levels are inappropriate with respect to the quantity of food consumed, inducing increased irreversible decarboxylation of leucine and incorporation of leucine-carbon into fat. It would further imply, that these increased insulin levels are effective in adipose tissue of PCS rats. It is true that insulin resistance is documented with regard to the metabolism of glucose and $\mathrm{BCAA}$ in cirrhotic patients $(20,21)$, but our data suggest that this does not occur in adipose tissue. This is in accordance with the very recently demonstrated absence of insulin receptor changes in adipose tissue of cirrhotic patients by Harewood et al (17).

A problem arises considering the importance of our results for the in vivo situation; Increased catabollism of leuclne and other BCAA in vivo may be counterbalanced by the decreased circulating plasma BCAA-1evels. However, Intracellular concentrations are reported to be normal or even increased (18). It is difficult to speculate about in vivo rates from DNA-corrected data. The ratio between leucine catabolism per mg wet welght of muscle and adipose tissue in vitro, combined with the percentage of these tissues of total body weight, may however apply to the in vivo stuation. Our data expressed per mg wet welght, demonstrated that in vitro leucine catabolism in muscle and adipose tissue, at a physiological leuclne concentration, is roughly equal per unit weight of elther tissue from PCS and control rats. In tissues from fed control rats, the in vitro leucine 
catabolisw in muscle is sightly higher than in adipose tissue, while in thases from fed PCS rats, the in witro leucine catabolism in adipose tissue is more pronounced. Assuning that muscle comprises approxtmately $40 \%$ of the total body weight, and adpose tissue $10 \%$, our data suggest that in nomal rats, adipose tissue nay netabollze approximately $25 \%$ of total ingested and endogenously released leucine. In PCS rats, adipose tissue plays a quantitatively more important role; the contribution of adipose tissue to leucine breakdown may be estimated to be $35 \%$ or more, depending on the total amount of adipose tissue, the number of actively leucine metabollzing fat-cells and probably the size of these cells.

ordinary rat chow contains approximately $25 \%$ protein by weight; it is egtimated that approximately $20-30 \%$ of this proteln consists of BCAA. The healthy rat needs only a small amount of these BCAA for proteln synthesis, so that the majority must be disposed of in another way. Muscle and adipose thssue are quantitatively the main organs that metabolize BCAA. Brain and kidney are able to metabolize significant amounts of BCAA per unit weight but this is less relevant for overall metabolism due to their small size. Excess of BCAA has therefore largely to be disposed of by degradation to. $\mathrm{CO}_{2}$ in muscle and adipose tissue, and by incorporation into fatty acids.

The increased leuctne catabolism after PCS, theasured in vitro in the presence of glucose, may contribute to the decreased plasma leucine level in PCS-rats. In this respect, another question remains to be answered. Does the increased in vitro degradation of leucine only result in decreased plasma leucine levels in vivo which in turn counterbalance ongoing degradation, or 1 s over-a11 catabolism induced due to a relative lack of leuclne? In this study, we only included PCS-rats that galned weight. Growth rate was proportlonal to food intake. At sacrifice, PCS rats had less fat and less muscle mass than controls, as evidenced by the weights of the diaphragms and epididymal fat pads that were excised and by tissue DNA-content of muscle and adipose tissue (table $I$ ). It is noteworthy that, although we excluded results from rats with low body weights (less than $110 \%$ of the preoperative weight) in this study, for reasons mentioned, the highest Incorporation rates in adipose tissue were recorded in these malnourished rats. It is, however, very unlikely that a lower growth rate and relative malnutrition may have caused the phenomena observed. While in 
long-tem starvation, decreased protein turnover and decteased fatty actd turnover occur and low insul in levels exist, in this study the oppostte was demonstrated in PCS rats. So, a specific effect of PCS itself seens responsible for the changes observed. Increased turnover of protein and/or fat has been observed in cirrhosis $(27,35)$, after trauma $(6,28)$ and in sepsis $(6,33)$ and has very recently also been reported in cancer cachexia (19). This suggests that stress-hormones may be concerned in the expression of the changes observed. Hyperimsulinism may be an integral part of a stressed state.

This study provides no definitive evidence that in PSS in vivo an increased catabolic rate is induced by increased breakdown of BCAA. Our data are in agreement with the hypothesis that increased in vitro catabolism of BCAA in PCS rats may be a consequence of increased a-KICA-DH activity in adipose tissue, induced by longlasting hyperinsulinism. Further studies to determine this a-KICA-DH activity in muscle and adipose tissue of PCS rats and their controls are described in chapter $V$. The increased in vitro catabolism of leucine in adipose tissue after PCS, may contribute to the decreased plasma leucine levels in PCS rats.

\section{References}

1. Ahlborg G, Felig P, Hagenfeldt L, et al: Substrate turnover during prolonged exercise 1 man: splanchnic and leg metabollsm of glucose, free fatty aclds and amino actds. J Clin Invest 53: 1080-1090, 1974.

2. Border JR, Chenier MD, McNemamy RH, et al: Multiple systems organ fallure. Muscle fuel deficit with visceral protein malnutrition. Surg C1in N Am 56: 1147-1167, 1976.

3. Burton $\mathrm{K}$ : A study of the conditions and mechanlsm of the diphenylamine reaction for the calorimetric estimation of deoxyribonucleic actd. Biochem I 62: 315-323, 1956.

4. Buse MG, Reid SS: Leucine: a possible regulator of proteln turnover in muscle. J Clin Invest 56: 1250-1261, 1975.

5. Child GC: The liver and portal hypertension. Major problems in clinical surgery. Saunders, Philadelphia, 1963

6. Clowes GHA Jr, George $B C$, Villee $\mathrm{CA} J r$, et al: Muscle proteolysis Induced by a circulating peptide in patients with sepsis or trauma. N Engl J Med 308: 545-552, 1983.

7. De Boer JEG, Oostenbroek RJ, Janssen MA, et al: Sequential metabollc characterlstics following portacaval shunt in rats. Eur Surg Res, in press. 
B. DLLley KJ, Rocek PH In: LKB Protein Chemistry Notes 10 and 11 (LKB Biochrom Ltd, Cambridge, Bngland) 1979.

9. Fellg $P$, Owen OR, Wahren J, et al: Amino acid metabolism during prolonged starvation. J Clin Invest 48: 584-594, 1969.

10. Fernstron $\mathrm{JD}$, Wurtman RJ, Hametstrom-wiklund $\mathrm{B}$, et al: Diurnal variations in plasma neutral anlno acid concentrations among patients with circhosis: effect of dietary protein. An J Clin Nutr 32: 1923-1933, 1979.

11. Fischer JE, Funovics $M$, Aquire $A$, et al: The role of plasma amino actdg in hepatic encephalopathy. Surgery 78: 276-280, 1975.

12. Fulks BM, Goldberg AL: Effects of Insulin, glucose and amino acid on proteln turnover in rat diaphragm. J Biol Chem 250: 290-298, 1975.

13. Funovlcs JM, Cunnings MG, Shuman L, tet a1: An improved nonsucure method for portacaval anastomosis in the rat. Surgery 77: 661-664, 1975.

14. Goodman HM: Stimulatory action of insulin on leucine uptake and metabollsm in adipose tissue. Am J Physiol 206: 129-132, 1964.

15. Goodman HM: Site of action of insulin in promoting leucline utilization in adipose tissue. Am J Physiol 233: E97-E103, 1977.

16. Goodman HM, Frick GP: Metabolism of branched chain amino acids in adlpose tissue. In: Walsher $M_{*}$ Williamson JE (eds): Metabolism and clinical implications of branched chain amino and ketoacids. Elsevier Morth-Holland, New York, p. 169-180, 1981.

17. Harewood MS, Proletto J, Dudiey F, et al: Insulin action and cirrhosis: insulin binding and lipogenesis in isolated adipocytes. Metabolism 31: $1241-1246,1982$.

18. Holm $E$, Leweling $H$, Staedt $U$, et al: Metabolic fate of branched chain aminoacids. In: Capocaccia L, Fisher JE, Rossi-Fanelli $F$ (eds): Hepatic encephalopathy in chronic liver fallure. Plemum Publishing Co, p $161-181,1984$.

19. Jeevanandan M, Horowitz GD, Lowry SF, et al: Cancer cachexla and proteln metabolism. Lancet I: 1423-1426, 1984.

20. Marchesini G: Relationship of carbohydrate and amino acid metabolism. Abstractbook 5th International Symposium on Ammonia, Semmering, Austriea, May 16-19, p 63, 1984.

21. Marchesind G, BlanchI G, Zoli M, et al: Plasma andno acid response to protela Ingestion in patients with liver disease. Gastroenterology $8.5: 283-290,1983$.

22. Millward DJ, Bates PC, Broadbent $P$, et al: Sources of urinary 3-methylhistidine in the body. In: Hesdorp RIC, Soeters PB (eds): Clintcal Nutrition ' $8 \%$, (Proceedings of 3rd ESPEN Congress, Maastricht sept. 1981), Churchill Livingstone, Edinburgh, p 190-203, 1982.

23. Munro HM, Fernstrom D, Wurtman RJ: Insulin, plasma amino acid imbalance and hepatic coma. Lancet I: $722-724,1975$.

24. Odessey R: Reversible ATP-induced inactivation of branched-chain 2-oxoacid dehydrogenase. Biochem J 192: 155-163,1980.

25. Odessey R, Goldberg AL: Oxidation of leucine by rat skeletal wuscle. An J Phystol 233: 1376-1383, 1972.

26. Odessey R, Khalrallah EZ, Goldberg A: Origin and possible significance of alanine production by skeletal muscle. J Blol Chem 249: 7623-7629, 1974.

27. O'Keefe S, Abraham $R$, Davis $M$, et al: Protein turnover in acute and chronic 11ver disease. Acta Chlr Scand, supp1 507: 91-101,1980. 
28. O'keefe SJD, Moldawer LL, Young VR, et al: The influence of intravenous nutrition on protein dynamics following surgery. Metabolism 30 * $1150-1157,1981$.

29. Parker PJ, Randle PJ: Active and inactive forms of branched chain 2-oxoacid dehydrogenase complex in rat heart and skeletal muscle. FEBS Lett 112: 186-190,1980.

30. Pector JC, Winand J, Dehaye JP, et al: Effects of portacaval shunt and transposition on fatty acid and cholesterol biosynthesis in rat liver. Am J Physiol 239: G83-G89, 1980.

31. Pozefskey T, Felig P, Tobin JD: Amino acid balance across tissues of the forearm in postabsorptive man. Effects of insulin a two dose levels. J Clin Invest 48: 2273-2282, 1969.

32. Rafael J, Vslansky P: Quantitative determination of nuclelc acids in brown and white adipose tissue. Anal Biochem 115: 158-162, 1981.

33. Rosenblatt $S$, Clowes GHA, George BC, et al: Exchange of aminoaclds by muscle and liver in sepsis. Arch Surg 118: 167-175, 1983.

34. Rossouw JE, Labadarios D, Vink AJ, et al: Liver glycogen after portacaval shunt in rats. Metabolism 27: 1067-1073, 1978.

35. Swart GR: Eiwitstofwisseling bij levercirrhose (Protein turnover in patients with cirrhosis of the liver). Thesis, Erasmus University, Medica Faculty, Rotterdam, 1984.

36. Wahren $\mathrm{J}$ : The interorgan exchange of amino acids in man. In: Wesdorp RIC and Soeters PB (eds): Clinical nutrition " 81 , (Proceedings of the 3rd ESPEN Congress, September 1981), Maastricht, The Netherlands, Churchil1 Livingstone, Edinburgh, p. 3-9, 1982.

37. Wannemacher RW Jr: Key role of varlous individual amino acids in host response to Infection. Am J Clin Nutr 30:1269-1280, 1977.

38. Ward MWN, Owens CWI, Rennie MJ: Nitrogen estimation in biological samples by use of chemiluminescence. Clin Chem 26: 1336-1339, 1980. 


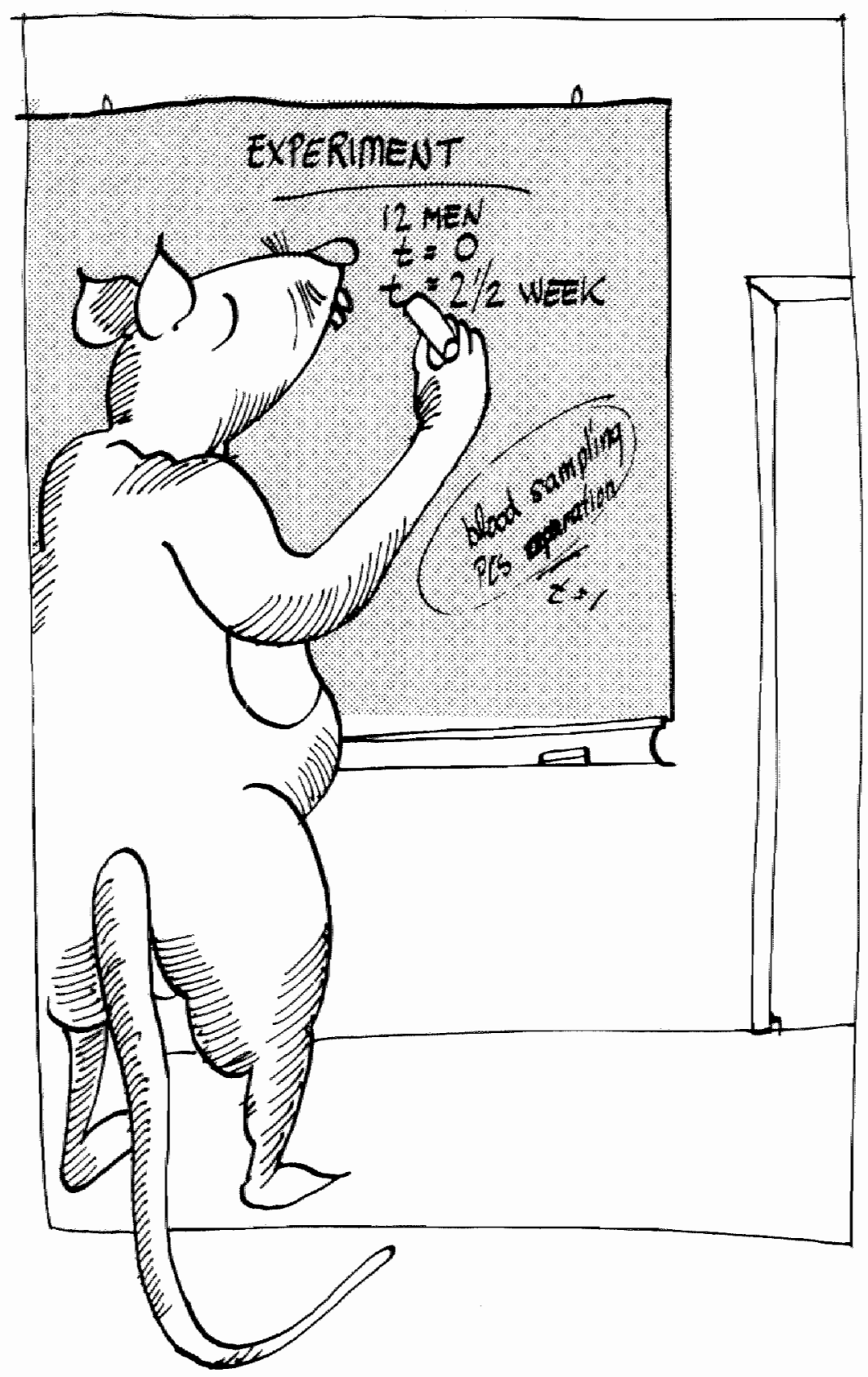



IN MUSCLE AND ADIPOSE TISSUE OF RATS

Decreased levels of branched chain amino acids (BCAA) in plasma exist in patients and experimental animals with portal-systemic shunting and hepatic insufficiency. The underlying mechanism is poorly understood. In a foregoing study, we reported an increased catabolism of leucine in vitro in peripheral tissues of porta-caval shunted (PCS) rats and the important role of adipose tissue in this catabolism. In this study, $2 \frac{1}{2}$ weeks after the PCS-operation, we investigate the in vitro metabolism of isoleucine and valine in diaphragm and adipose tissue from PCS-operated rats. The distribution of the incorporation of leucine-, isoleucine- and valine-derived carbon into different fat-fractions in adipose tissue is traced and the influence of addition of leuctne on isoleucine- and valine catabolism studied. The results indicate that:

1. After PCS, in vitro isoleucine- and valine catabolism are increased in adipose tissue derived from fed rats and resembles the alterations measured with leucline under the same conditions: The increased decarboxylation rate of valine is augmented (isoleucine could not be measured) and a pronounced increase of incorporation of BCAA-derived carbon into fat in adipose tissue is found. In addition, increased catabolism of ${ }^{14} \mathrm{C}-(\mathrm{U})$-valine-derived carbon to $\mathrm{CO}_{2}$ is observed.

2. In muscle, the rate of decarboxylation of valine is decreased after PCS. The incorporation of isoleucine and valine into muscle protein is significantly increased after PCS.

3. The highest levels of incorporation of BCAA-derived carbon into fat in adipose tissue from both control- and PCS-operated rats are measured after incubation with leucine, whereas the lowest levels are found after incubation with valine.

4. The increased incorporation of BCAA-dertved carbon into fat in adipose tissue after PCS is largely into the triglyceride fractlon.

5. Incorporation of isoleucine-derived carbon into fat in adipose tissue (1.e. triglyceride synthesis) from both normal and PCS rats 18 enthanced in the presence of leucine in a physiological concentration.

The increased catabolism of all three BCAA In adipose t1sgue after PCS may contribute to the decrease of plasma BCAA levels after PCS. Because 
increased protein synthesis and fatty acid synthesis in the PCS rats is accompanted by decreased muscle mass and fat mass, the data suggest that PCS laduces increased mucle protein turnover and fatty acid turnover. In viwo, this may remult in diminished growth or, in severe conditions, in net catabollsm.

\section{Introduction}

Plasma branched chain amino acid (BCAA) levels are decreased in patients and expertmental anlmals with impaired liver function and/or portal-systemic shunting (PSS) (3). BCAA are almost completely metabolized peripherally in muscle and adipose tissue. Kldney and brain play a minor role due to the correspondingly smaller amount of tissue (chapter I). In in vitro incubation studies, we investgated the metabolism of leucine in dilaphragm and epldidymal adipose tissue derived from normal and porta-caval shunt (PCS) operated rats which have been shown to exhibit decreased plasma BCAA levels (chapter II and III). It was demonstrated that, expressed per $\mu \mathrm{g}$ DNA, PCS increased in vitro in adipose tissue the catabolism of leucine by Increasing irreversible decarboxylation of the $\mathrm{C}-1$ atom of leucine in adtpose tissue and subsequently by increasing the incorporation of leuclne-derlved carbon into fat (chapter III). These in vitro results suggested that the low plasma leucine levels are due to increased peripheral leucine catabolism in adipose tissue after PCS,

The rate-11miting enzyme in the degradation of leucine in most tissues, the a-keto isocaprolcacid dehydrogenase (a-KICA DH), also catalyses the irteverstble decarboxylation of the other BCAA, 1soleucine and valine. Low plasma levels of these amino acids after PCS, might also be due to lacreased perlpheral catabolism. To gain support for this hypothesis, we measured the influence of PCS on the in vitro catabolism of isoleucine and waline in muscle and adipose tissue in the presence of physiological concentrations of ${ }^{14} \mathrm{C}-(U)$-isoleucine, ${ }^{14} \mathrm{C}-(1)$-valine or ${ }^{14} \mathrm{C}-(U)$-valine (0.1 $\mathrm{mM}) ;{ }^{14} \mathrm{C}-(1)$-isoleucine was not commerclally avallable.

In the studies with leucine, the greatly increased incorporation of leucine-derived carbon into fat in adlpose tissue after PCS, was an unexpected finding. We therefore determined, in this study, in which fraction(s) the leuctne-derlved carbon, and also isoleuctne- and valine- 
derived carbon, could be detected. In vivo, all three BCAA are present together and the metabolism of the BCAA may be influenced by each other. Special regulatory properties are ascribed to leuclne $(1,5,6)$. Therefore, the influence of leucine on the irreversible $\mathrm{C}-1$ decarboxylation was measured. Furthermore, the distribution of isoleuclne- and valine-derived carbon in the different fat-fractions was traced after incubation of the tissues with these amino acids in the presence of a physlologlcall concentration of unlabeled leucine. In all these experiments, tissues from pCs operated and sham-operated rats were compared.

Materials and methods

PCS operations were performed in male Sprague-Dawley rats. Rats used in experiments were selected according to the criteria described before (chapter II). All these rats had proven hyperinsulinism, decreased plasma BCAA levels and positive nitrogen balance as evidenced by welght gain. Diaphragm and epididymal adipose tissue of these rats were used for the incubation experiments $2 \frac{1}{2}$ weeks postoperatively. The incubation procedure and the techniques to measure ${ }^{14} \mathrm{CO}_{2}$-release, incorporation into muscle protein and into fat in adipose tissue, from BCAA-derived carbon, have been described before (chapter III).

For determination of the distribution of BCAA-derived carbon in fat in adipose tissue, the following procedure was used. Immediately after incubation, the adipose tissue fragments $(30-40 \mathrm{mg})$ were removed and frozen in liquid nitrogen. To minimize the action of lipolytic enzymes, the frozen tissue pieces were pulverized in an aluminium mortar that had been cooled in liquid nitrogen. Fat was extracted with a chloroform-methanol mixture (2:1) and dried under nitrogen atmosphere. For separation of the fatfractions by thin-layer chromatography (TLC), the sample was dissolved in chloroform-methanol (1:1). One third of this sample was added to a TLCplate (pre-coated TLC plates; silica gel 60 F-254, $0.5 \mathrm{~mm}$, Merck, Darmstadt, Germany). The mobile phase existed of petroleum ether (bolling-range $\left.60-80^{\circ} \mathrm{C} ; 120 \mathrm{ml}\right)$, diethyl ether $(25 \mathrm{ml})$ and glacial acetic acld $(1.5 \mathrm{ml})$ and contained butylated hydroxy toluene (o-cresol butylether; $50 \mathrm{mg} / 1)$, which was also present in the extraction fluid. Radioactivity in some 


\section{BCAA METABOLISM \\ METABOLIZED TO $\mathrm{CO}_{2}$}

\section{DIAPHRAGM}

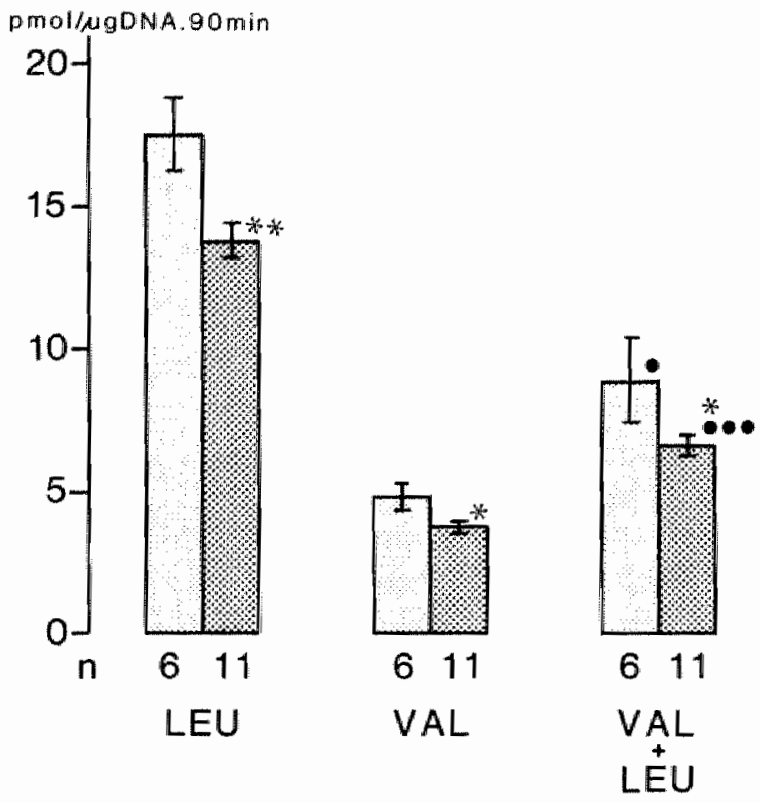

Figure la

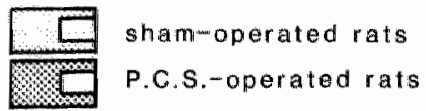

4 * compared with sham-operated cantrols

ol influence of unlabeld $L$-leucine

$\Delta / O=p<0.10 ; * / \omega=p<0.05 ; * *=p<0.01 ; \omega 0=p<0.001$

Figure 1

Valine metabolism to $\mathrm{CO}_{2}$ in vitro in diaphragm ( $1 \mathrm{a}$ ) and epldidymal adipose tissue (16) derived from fed sham-operated and, $P C S$-operated rats $\left(2 \frac{1}{2}\right.$ weeks p.o.), measured in the presence of $0.1 \mathrm{mM}{ }^{14} \mathrm{C}-(1)-\mathrm{L}$-valine, ${ }^{14} \mathrm{C}-(\mathrm{U})-\mathrm{L}-$ valine (s.a. $0.25 \mathrm{mCl} /$ mol $)$ or with extra unlabeled leucine $(0.1 \mathrm{mM})$. 


\section{BCAA METABOLISM \\ METABOLIZED TO $\mathrm{CO}_{2}$ \\ EPIDIDYMAL ADIPOSE TISSUE}
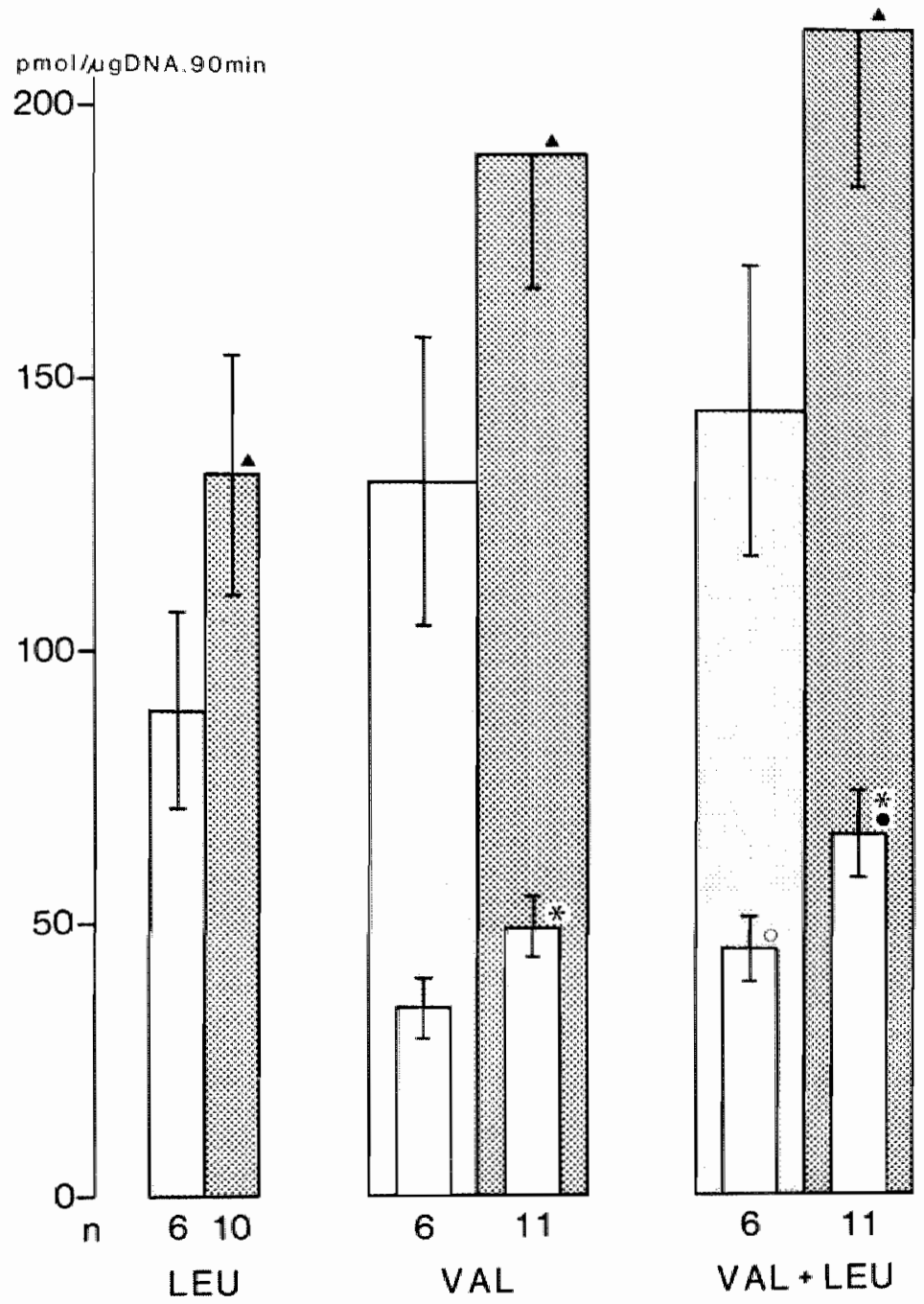

F1gure $1 \mathrm{~b}$

Measurements with ${ }^{14} \mathrm{C}-(1)$-L-leucine were included as control, allowing a valid comparison with experiments described in chapter III. Results are expressed in pmol/ $\mu \mathrm{g}$ DNA.90 min. (mean \pm sem). The narrow or inner bars represent results obtained with ${ }^{14} \mathrm{C}-1$ labeled components; the wide bars represent results obtalned with ${ }^{14} \mathrm{C}$-(U) labeled components. 
fractions was too 10w to allow detection by scanning the thin layer plates. directly. Therefore, the fat fractions were ldentifled by lodine wapour, gcraped off and the radioactivity was measured by liquid scintillation counting. Identiflcation of the fractions was factiltated by the use of purified standards (phospholipids, diglycerides, cholesterol, free fatty acdis, triglycerfdes and cholesterol-esters) and/or by addition of tritium labeled purlfied components.

${ }^{14} \mathrm{C}-(\mathrm{U})-\mathrm{L}$-Isoleuclne (s.a. $\left.335 \mathrm{mCi} / \mathrm{mol}\right),{ }^{14} \mathrm{C}-(\mathrm{l})-\mathrm{L}$-valine (s.a. 48 $\mathrm{mCl} /$ manol) and ${ }^{14} \mathrm{C}-(U)-\mathrm{L}$-valine (s.a. $295 \mathrm{mCl} / \mathrm{mmol}$ ) were purchased from wew England Nuclear Corp. (Boston, Mass.). Counting solution Pico-fluor 15 and the tissue solubllizer Soluene ${ }^{\mathrm{R}}-350$ were obtained from Packard-Becker B.V., (Chemical Operations, Groningen, The Netherlands). All other reagents were analytical grade. Glucose ( $5 \mathrm{mM}$ ) was present in the Krebs-Ringer incubation medium. The final concentration of isoleucine and valine was $0.1 \mathrm{~m}$ and the s.a. $0.25 \mathrm{mCl} / \mathrm{mmol}$. In the experiments in which $\mathrm{BCAA}$-derived ${ }^{14} \mathrm{C}$ was traced in the different fat-fractions, the specific activity of the BCAA used was $2.5 \mathrm{mCl} / \mathrm{mmol}$. Tissue DNA content was determined in muscle according to Burton (2) and in adipose t1ssue according to Rafael and Vslansky ( 7 ).

\section{Results}

In accordance with data from earlier experiments, plasma insulin was increased by $35 \%$ two-and-a-half weeks after the PCS operation and plasma glucagon, by $100 \%$ (both measured after an avernight-fast), while plasma BCAA levels were decreased by approximately $30 \%$ and phenylalanine and tyrosine were lncreased (92 and $23 \%$, respectively; amino acids measured in fied state). All results from the tissue-incubation experiments are derived with tissues from fed rats, and expressed in pmol/ $/ \mathrm{g}$ DNA.90 min. to correct for different numbers of cells.

Incubations with ${ }^{14} \mathrm{C}-(U)-\mathrm{L}-1$ soleucine, ${ }^{14} \mathrm{C}-(1)-\mathrm{L}$-valine and with ${ }^{14} \mathrm{C}-(\mathrm{U})$-L-valine.

\section{Diaphragm.}

Irreversible decarboxylation of ${ }^{14} \mathrm{C}-(1)$-valine in muscle was significantly decreased after $\operatorname{PCS}(\mathrm{p}<0.05 ; \mathrm{flg} .1 \mathrm{a})$. The amount of isoleucine- 

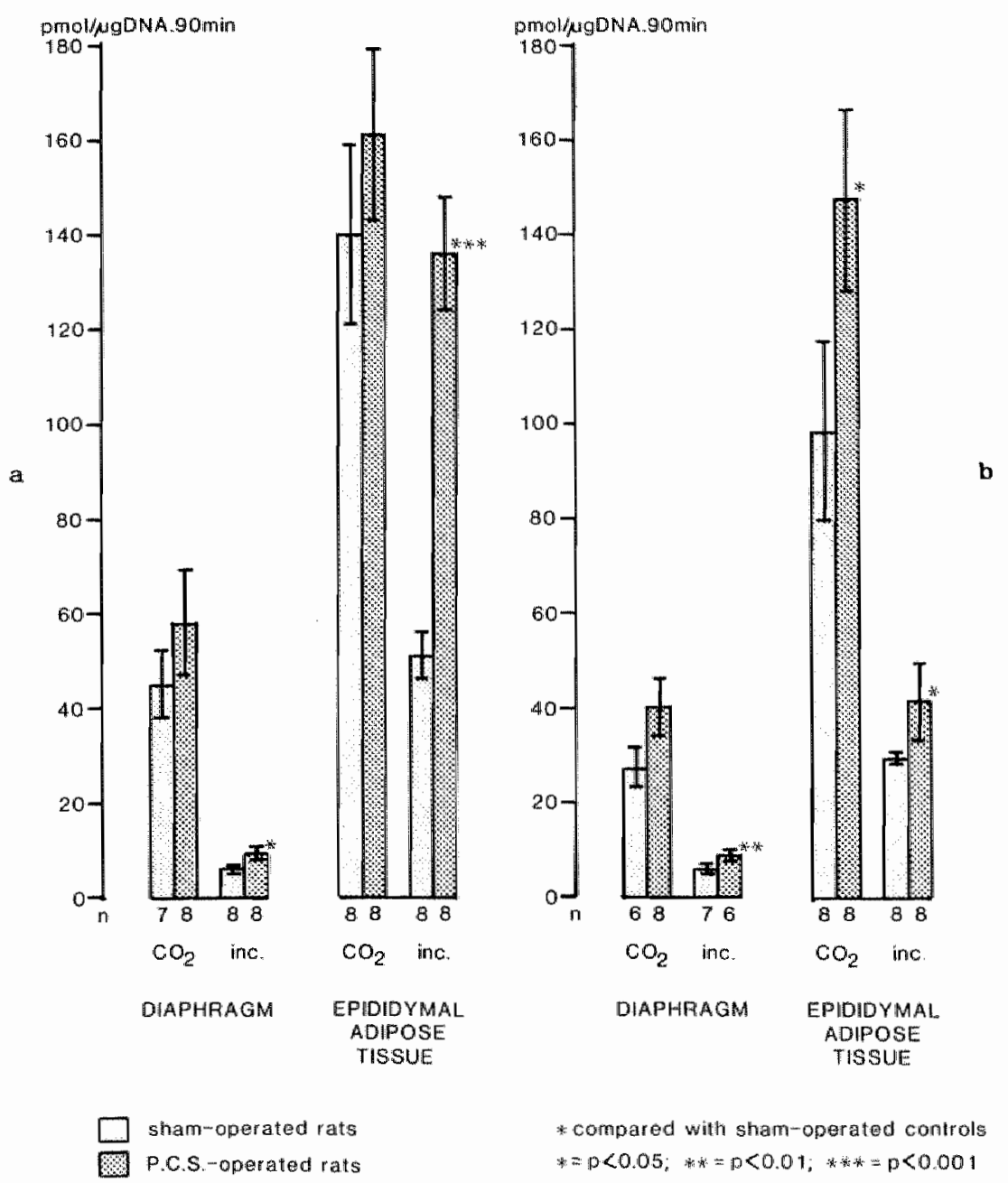

Figure 2

Isoleucine- and valine metabolism in witro in diaphragm and epldidymal adipose tissue derived from fed sham-operated and PCS-operated rats (2L weeks p.0.) measured in the presence of $0.1 \mathrm{mM}{ }^{14} \mathrm{C}-(\mathrm{U})-\mathrm{L}-1$ soleucline (2a) and $0.1 \mathrm{mM}{ }^{14} \mathrm{C}-(\mathrm{U})-\mathrm{L}-$ waline $(2 \mathrm{~b})$. Tissue pieces $(30-40 \mathrm{mg})$ were, immediately after removal from the rats, incubated in Krebs-Ringer bicarbonate buffer $\mathrm{pH} 7.4$, including $5 \mathrm{mM}$ glucose, in a shakerbath at $38.5^{\circ} \mathrm{C}$ for 90 min. The reaction was started after a $10 \mathrm{mln}$. preincubation by addition of the labeled substrates. Anino acid-derived carbon released as $\mathrm{CO}_{2}$ by diaphragm, incorporation of amino acid into muscle protein, amino acidderived carbon released as $\mathrm{CO}_{2}$ by epldidymal adipose tissue and incorporation of amino acid-derived carbon into fat in adipose tissue are given separately, from left to right. The procedure for these measurements has previously been described (chapter III). Results are expressed in pmol/ $\mu g$ DNA. 90 min. (mean \pm sem). 
carbon and valine-carbon derlved $\mathrm{CO}_{2}$ * produced in vitro by diaphragm from PCS rats, was not siguificantly altered compared to the sham-operated controls in the presence of $0.1 \mathrm{mM}{ }^{14} \mathrm{C}-(\mathrm{U})-\mathrm{L}-1$ soleucine or $0.1 \mathrm{mM}$ ${ }^{14} \mathrm{C}-(u)-v a l$ ine in the incubation medium but had a tendency to be increased after PCS, when $0.1 \mathrm{mM}{ }^{14} \mathrm{C}-(\mathrm{U})$-L-valine was present $(\mathrm{p}<0.1 ; \mathrm{f1g} \cdot 2 \mathrm{a}$ and 2b). Incorporation of isoleucine and valine into muscle protein in vitro was increased after PCS $(\mathrm{p}<0.05$ and $\mathrm{p}<0.005$, respectively).

Adipose tisisue.

Irreverstble decarboxylation of ${ }^{14} \mathrm{C}$-(1)-valine in adipose tissues was signiflcantly increased after PCS ( $\mathrm{p}<0.05$; fig. Ib). $\mathrm{CO}_{2}$-production from isoleuctne-derived carbon by eptdidymal adipose tissue in vitro, was not significantly altered by PCS, while in the presence of valine a significant increase in $\mathrm{CO}_{2}$-production was recorded $(\mathrm{p}<0.05)$. The incorporation of both 1 soleucine- and valine-derived carbon 1 to fat in adipose tissue was enhanced $(p<0.001$ and $p<0.05$ respectively; $f(g .2 a$ and $2 b)$.

Levels that were recorded for valine-derived catbon were lower than for isoleuclne-derived carbon, except in the incorporation of these amino acids into muscle protein, which was approximately equal in control rats.

Distribution of ${ }^{14} \mathrm{C}-(\mathrm{U})-\mathrm{L}-\mathrm{BCAA}$ derived carbon $1 \mathrm{n}$ fat from PCS-operated and sham-operated rats.

The differences in the in vitro rates af metabolism of leucine, isoleuctne and valine, present at a $0.1 \mathrm{mM}$ concentration, in muscle and adpose tissue from PCS- and sham-operated rats, were similar. The increased incorporation of BCAA-derived carbon into fat in adipose tissue of pCs-operated rats was most pronounced. The measured levels for both control- and PCS-rats decreased in the order leuctine $>$ isoleucine $>$ valine, which was least incorporated into fat. In another group of control and PCS rats, selected according to the same criterla, the distribution of the BCAA-derived carbon incorporated in vitro Inta different fractions of fat, was investigated. Fat was extracted and separated as described in Materials and nethods. The results are expressed in pmol/ $/ \mathrm{g}$ DNA. $90 \mathrm{~min}$. and plotted in fig. 3a, 3b and 3c for leucine-, isoleucine- and valine-derived carbon, respectively. Fig. 3 demonstrates that the in vitro additionally incorporated BCAA-derived carbon Into adipose tissue after PCS is largely 


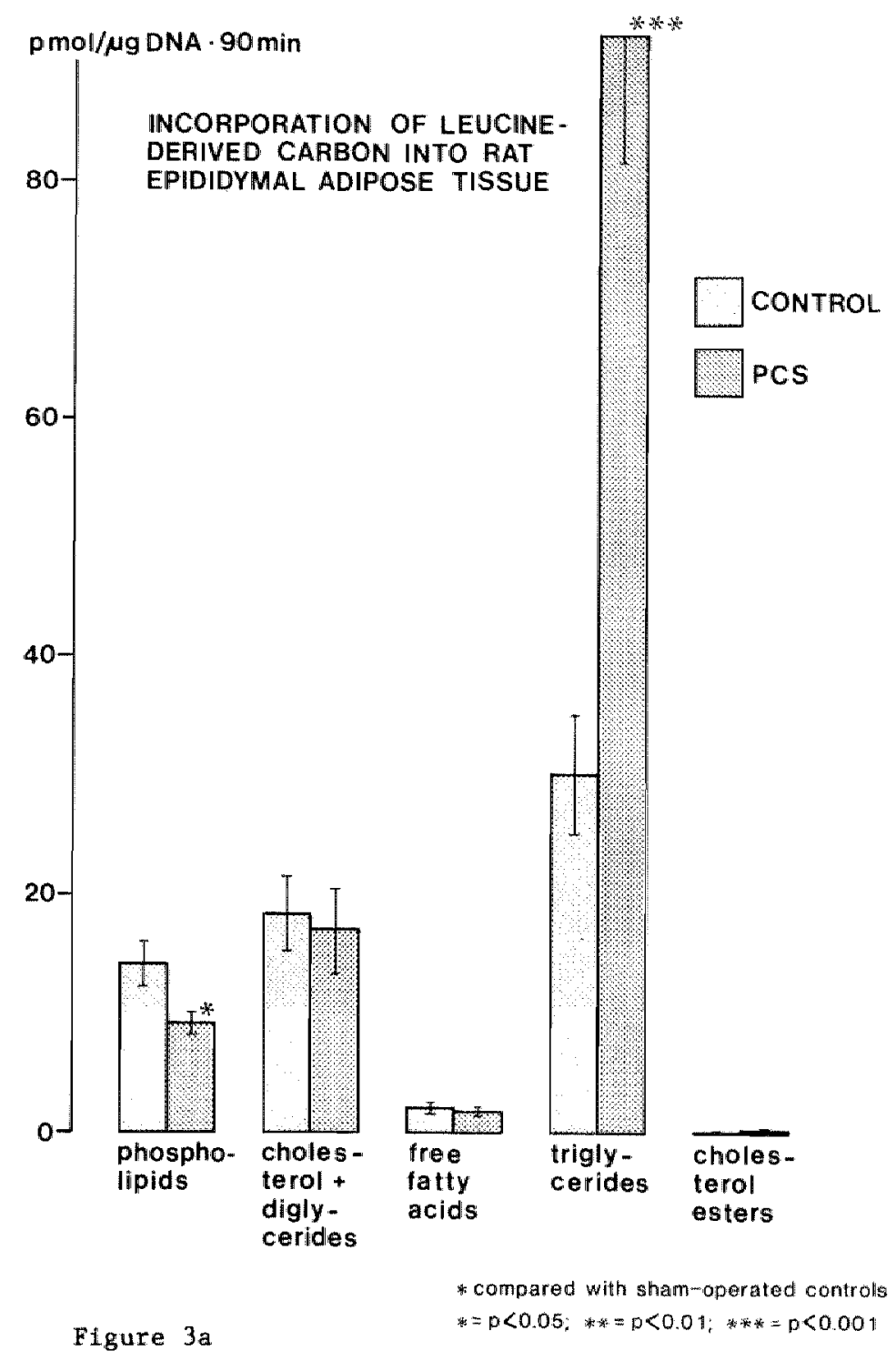

Figure 3

Distribution of ${ }^{14} \mathrm{C}-(U)-\mathrm{L}-\mathrm{BCAA}$ dertwed carbon in fat in tissues from PCSoperated and sham-operated rats. For detalls see Materials and methods. The results are expressed in pmol/ $\mu \mathrm{g}$ DNA.90 min. and given $\mathrm{in} \mathrm{fig.} \mathrm{3a,} \mathrm{3b} \mathrm{and}$ $3 c$ for leucine-, isoleucine- and vallne-derived carbon respectively (mean \pm sem; $n=10$, except in PCS group with leucine $(n=12)$ and sham-operated group with valine $(n=13))$. 
INCORPORATION OF ISOLEUCINE DERIVED CARBON INTO RAT

EPIDIDYMAL ADIPOSE TISSUE

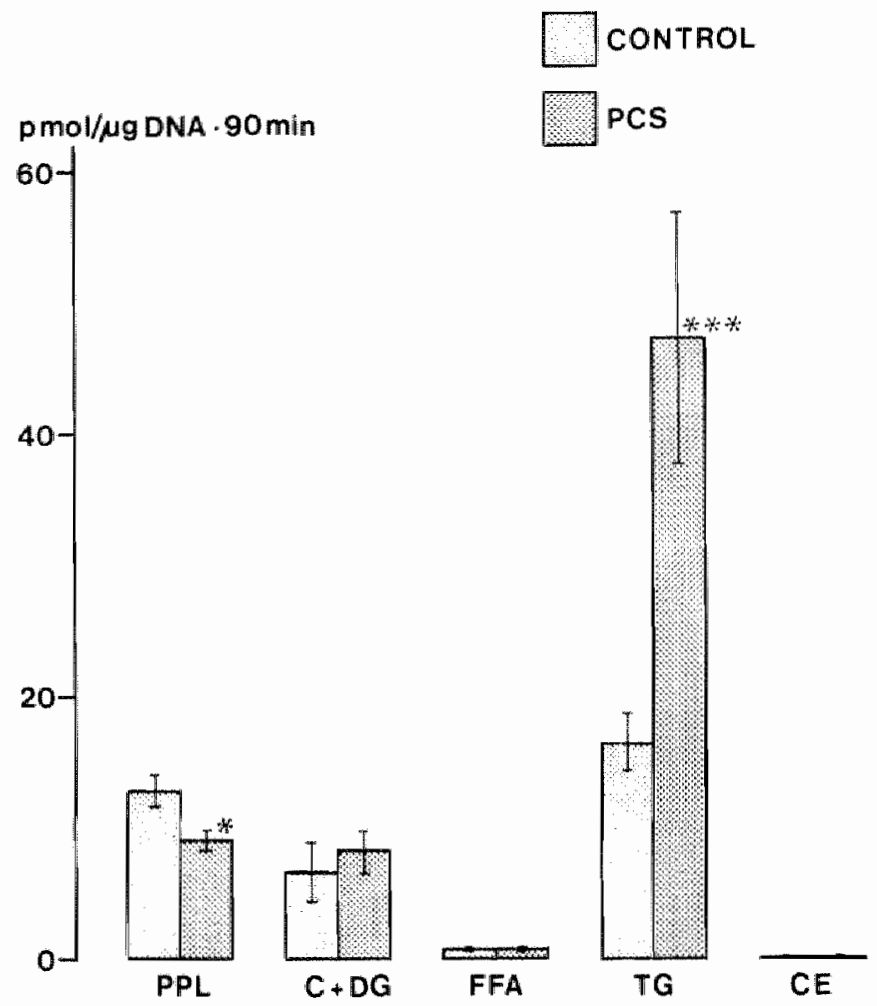

compared with sham-operated controls $y=p<0.05 ; \quad x=0<0.0 \% * x-p<0.001$

Figure $3 b$

(see legend p. 93) 
INCORPORATION OF VALINE -

DERIVED CARBON INTO RAT

EPIDIDYMAL ADIPOSE TISSUE

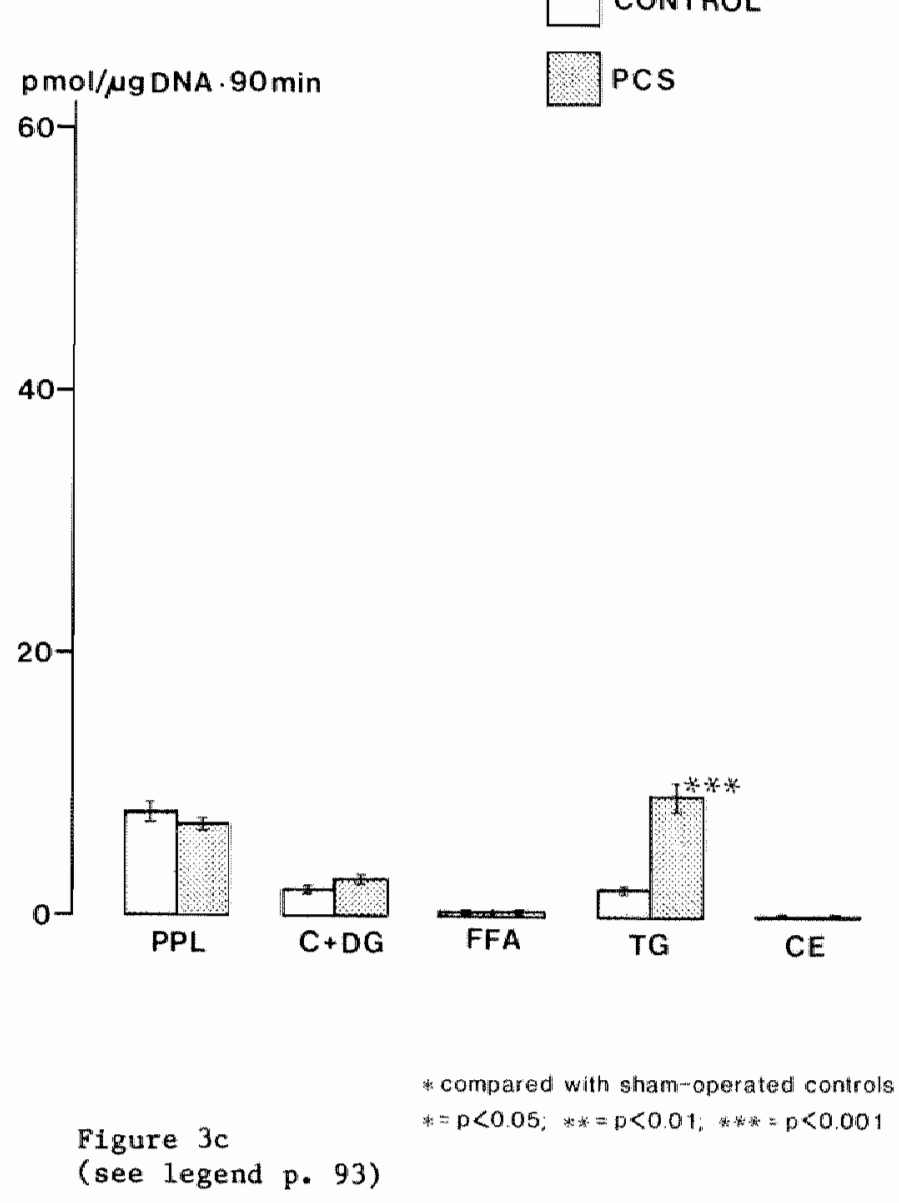


accounted for by fatty acid synthesis which is mainly used for the formation of triglycerides. Diglycerides and cholesterol were poorly separated in these studies and are therefore shown as one fraction. The incorporation of leucine- and isoleucine-derived carbon into phospholipids was decreased 1n the PCS group $(p<0.05)$. As expected, all measured levels decreased in the order leuclne $>$ isoleucine $>$ valine.

\section{Influence of leucine on isoleuclne and valine metabollsm}

A simllar experiment was carried out with adipose tissue from a third group of PCS-rats and their sham-operated controls. In this experiment, the incorporation of amino acid-derlved carbon into fat and the distribution over the fat-fractions were measured in the presence of $0.1 \mathrm{mM}{ }^{14} \mathrm{C}-(\mathrm{U})-\mathrm{L}^{-}$ Isoleucine or $0.1 \mathrm{mM}{ }^{14} \mathrm{C}-(U)-\mathrm{L}-\mathrm{valine}$ in the incubation medium, and in the presence of these labeled amino acids $(0.1 \mathrm{mM})$ in combination with $0.1 \mathrm{mM}$ unlabeled L-leuclne. The results are listed in table $\mathrm{I}$. Comparison of the results derived with tissues from PCS rats and contral rats are in good agreenent with the experiments described above. Significant increases were measured in the incorporation in vitro of isoleucine- and valine-derived carbon into triglycerides after $\operatorname{PCS}(p<0.05$ and $p<0.01$, respectively). In the presence of an additional $0.1 \mathrm{mM}$ unlabeled leucine in the incubation medium, similar increases in incorporation into triglycerides after PCS were recorded with equal significances (table I; fig. 4). The presence of additional (unlabeled) leucine tin the 1 ncubation mediun $(0.1 \mathrm{mM})$ increased the incorporation of ${ }^{14} \mathrm{C}-(\mathrm{U})$-1soleuclne-derlved carbon into triglycerides In adipose tissue from $P C S$ rats $(p<0.05)$ and tended to increase the incorporation in adipose tissue from control rats, howewer no significance was reached in this case. Incorporation of ${ }^{14} \mathrm{C}-(\dot{U})$-valine-derived carbon into triglycerides in adipose tissue was not altered by the presence of additional leucine (fig. 4 ).

No significant increases were noted in incorporation into other fat fractions between PCS- and control rats. A decrease was noted in incorporation of valine-derived carbon into cholesterol in the PCS-group (table I; $\mathrm{p}<0.05$ ), when no unlabeled leucine was present. 


\begin{tabular}{|c|c|c|c|c|}
\hline \multirow[b]{2}{*}{ Fraction } & \multicolumn{2}{|c|}{$0.1 \mathrm{mM}{ }^{14} \mathrm{C}-(\mathrm{U})$-isoleucine } & \multicolumn{2}{|c|}{$\begin{array}{l}0.1 \mathrm{mM}{ }^{14} \mathrm{C}-(\mathrm{U})-1 \text { soleucline } \\
+0.1 \mathrm{mM} \text { leucine }\end{array}$} \\
\hline & Sham-op. & PCS-op. & Sham-op. & PCS-op. \\
\hline P1 & $15.2 \pm 0.9$ & $12.4 \pm 1.6$ & $17.1 \pm 1.1$ & $15.8 \pm 1.6$ \\
\hline$D G$ & $13.0 \pm 3.0$ & $9.0 \pm 1.7$ & $19.0 \pm 4.0$ & $12.4 \pm 1.7 *$ \\
\hline Chol & $1.9 \pm 0.4$ & $1.8 \pm 0.5$ & $2.4 \pm 0.4$ & $2.2 \pm 0.5$ \\
\hline FFA & $0.7 \pm 0.1$ & $0.8 \pm 0.2$ & $0.7 \pm 0.1$ & $1.1 \pm 0.2$ \\
\hline TG & $40.0 \pm 9.0$ & $69.0 \pm 10 *$ & $48.0 \pm 7.0$ & $102.0 \pm 18.0 * 0$ \\
\hline $\mathrm{CE}$ & $0.1 \pm 0.1$ & $0.1 \pm 0.05$ & $0.1 \pm 0.1$ & $0.1=0.1$ \\
\hline
\end{tabular}

\begin{tabular}{|c|c|c|c|c|}
\hline \multirow[b]{2}{*}{ Fraction } & \multicolumn{2}{|c|}{$0.1 \mathrm{mM}{ }^{14} \mathrm{C}$-(U)-valine } & \multicolumn{2}{|c|}{$\begin{array}{l}0.1 \mathrm{mM}{ }^{14} \mathrm{c}-(\mathrm{U}) \text {-waline } \\
+0.1 \mathrm{mM} \text { leucine }\end{array}$} \\
\hline & Sham-op. & PCS-op. & Sham-op. & PCS-op. \\
\hline P1 & $8.5 \pm 0.5$ & $8.0 \pm 0.7$ & $7.3 \pm 0.8$ & $7.2 \pm 0.5$ \\
\hline DG & $3.3 \pm 0.7$ & $2.6 \pm 0.6$ & $3.3 \pm 0.8$ & $2.5 \pm 0.5$ \\
\hline Chol & $0.8 \pm 0.1$ & $0.4 \pm 0.1 *$ & $0.7 \pm 0.1$ & $0.6 \pm 0.1$ \\
\hline FFA & $0.4 \pm 0.1$ & $0.2 \pm 0.1$ & $0.4 \pm 0.1$ & $0.3 \pm 0.1$ \\
\hline TG & $8.6 \pm 1.2$ & $20.0 \pm 3.0 * *$ & $9.0 \pm 2.0$ & $21.0 \pm 3.0 * *$ \\
\hline $\mathrm{CE}$ & $0.1 \pm 0.0$ & $0.1 \pm 0.0$ & $0.1 \pm 0.1$ & $0.1 \pm 0.0$ \\
\hline
\end{tabular}

Table I.

Distribution of ${ }^{14} \mathrm{C}-(U)-\mathrm{L}-1$ soleucine and ${ }^{14} \mathrm{C}-(U)$-L-valine-deriwed carbon in fat in tissues from PCS-operated $(n=8)$ and sham-operated rats $(n=5)$, without and in the presence of unlabeled leucine $(0.1 \mathrm{mM})$. Results are expressed in pmol/ $\mu \mathrm{g}$ DNA. $90 \mathrm{~min}$. (mean \pm sem). Significances between shamand PCS operated rats are indicated by aster1sks (* $p<0.05 ; * \star p<0.01)$; significances due to the presence of unlabeled leuclne by open circles $(0 \mathrm{p}<0.05)$.

PL: phospholipids; FFA: free fatty acids;

DG: diglycerides; TG: triglycerides;

Chol: cholesterol; CE: cholesterol esters. 


\section{IMCORPORATION OF BCAA - DERIVED CARBON INTO TRIGLYCERIDE IN RAT EPIDIDYMAL ADIPOSE TISSUE}

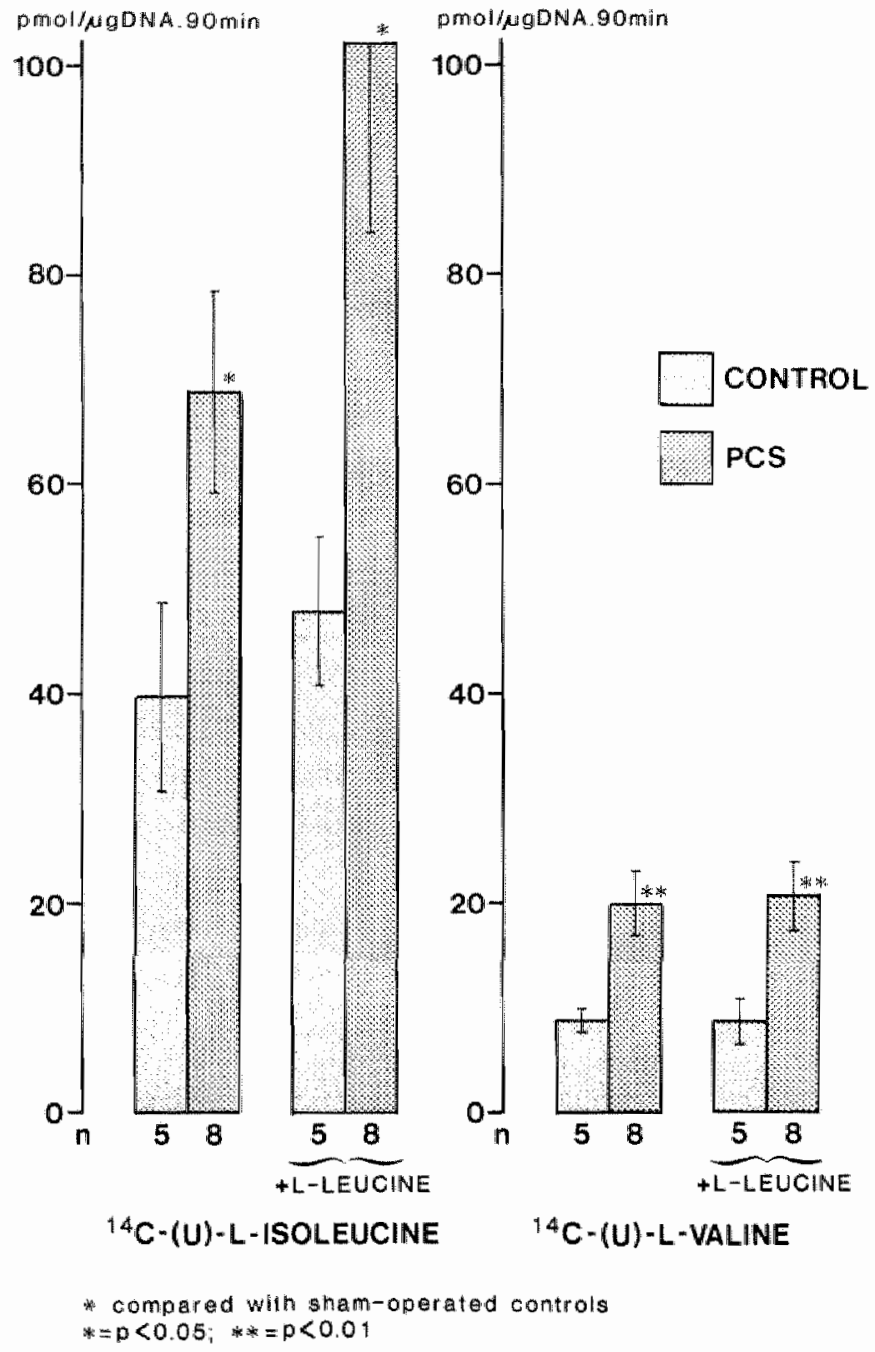

Figure ${ }^{4}$ Incorporation of ${ }^{14} \mathrm{C}-(U)-\mathrm{L}-1$ soleucine and ${ }^{14} \mathrm{C}-(U)$-L-valine-derived carbon into triglycerides in adpose tissues from PCS-operated and sham-operated rats, without and in the presence of unlabeled leucine $(0.1 \mathrm{mM})$. Results are expressed in pmol/ $\mu \mathrm{g}$ DNA.90 min. (mean \pm sem). Significances are indicated as in table $\mathrm{I}$. 
The metabolism of isoleucine and valine in muscle and adipose tissue from PCS rats and sham-operated controls, as measured in vitro in incubation experiments in the presence of $0.1 \mathrm{mM}{ }^{14} \mathrm{C}-(\mathrm{U})$-isoleucine, ${ }^{14} \mathrm{C}$-(1)-valine or $14 \mathrm{C}$-(U)-valine, greatly resembled the metabolism of leucine, measured under identical conditions: an increased BCAA catabolism in adipose tissue after PCS, and no change or a small decrease in BCAA catabolism, in muscle. The recorded levels, however, were generally lower with isoleucine and valine than with leucine (chapter III). The limportant role of adipose tissue in BCAA-catabolism, especially after PCS, was once more demonstrated. The enhanced incorporation of BCAA-derived carbon into the storage component triglyceride after PCS and the increased Incorporation of $\mathrm{BCAA}$ into muscle protein, must imply that the turnover of fatty acids in adipose tissue and protein in muscle are increased, because of the generally smaller fat and muscle mass in PCS rats. The increased catabolism of BCAA in vitro in adipose tissue after PCS may contribute to the decreased BCAA-levels in plasma in vivo in case of portal-systemic shunting. The decarboxylation rates of leucine and valine are increased after PCS to approximately the same degree. Although the rate of decarboxylation of isoleucine could not be measured, it may be expected to be increased after PCS, judging from the results with universally labeled isoleucine. So, the rates of decarboxylation of all three $B C A A$ appear to be increased to the same extent. This may explain the approximately equal decrease of BCAA levels in the plasma after PCS.

Metabolism from ${ }^{14} \mathrm{C}-(U)$-1soleucine and ${ }^{14} \mathrm{C}-(U)$-valine derived carbon to $\mathrm{CO}_{2}$ by both muscle and adipose tissue (flg. $2 \mathrm{a}$ and $2 \mathrm{~b}$ ) were not significantly altered by PCS except in adipose tissue with valine, although a tendency to be increased after PCS was noted. Incorporation of lsoleucine and valine into muscle protein was significantly increased in the PCS-operated group, while, after PCS, the increase of 1soleucine- and valine derived carbon into fat in adipose tissue was most pronounced when isoleucine served as substrate. So, of all three BCAA, the metabolism of ${ }^{14} \mathrm{C}$-(U)-valine to $\mathrm{CO}_{2}$ in adipose tissue after PCS is proportionaliy more increased than fatty acid synthesis, while the increase in irreversible 
decarboxylation Erom ${ }^{14} \mathrm{C}-(1)$-valine after PCS 1 s comparable to leucine ( 1 fg. $\mathbb{B b}$ and $f 1 g$. 2). Consequently, the valine carbon skeleton is, compared wth leuclne and isoleucine, more completely oxidized to $\mathrm{CO}_{2}$ in adipose tissue after PCS.

Furthermore, it can be calculated from $f(1 g .1$ and $f i g .2$, by comparison of the data obtained with ${ }^{14} \mathrm{C}-(1)$-valine and ${ }^{14} \mathrm{C}$-(U)-valine, that the carbon atoms of all valine that is irreversibly decarboxylated in adipose tissue, are metabollized to $\mathrm{CO}_{2}$ or used for fatty acid synthesis, as has been shown for leucine in chapter III. In contrast to the complete degradation of waline in adipose tissue, a significant part of the irreversibly decarboxylated valine in muscle cannot be accounted for by metabollsm to $\mathrm{CO}_{2}$, indlcating an incomplete degradation in muscle. This was also shown for leucine (chapter III).

Differences in the recorded levels between leucine-, isoleucine- and valine-oxidation to $\mathrm{CO}_{2}$ in adipose tissue from normal rats are in agreement Wth data reported by Rosenthal et al, Tischler et al and Frick et al $(4,8,9)$. These differences may be explained by different rates of decarboxylation of the three BCAA determined by different affinities of the BCAA for the rate-1imiting enzyme in the degradation in muscle and adipose tiesue, and were also seen in vitro with tissues from PCS rats (fig. 1). Differences in transamination rates of leucine, isoleucine and valine may also occur in peripheral tissues, but are less relevant for the degradation rates of BCAA than the activity of the rate-limiting branched chain oxoacid dehydrogenase (BCOA-DH). The presence of leucine may have an additional. effect on the activity of the $\operatorname{BCOA}-\mathrm{DH}(1,4,5)$.

The Increased incorporation of $\mathrm{BCAA}-\mathrm{der}$ ived carbon into fat in adipose tissue after PCS was very interest1ng. The Increased incorporation of BCAAderived carbon into triglycerides was completely responsible for this (fig. 3). Different levels of incorporation of leucine-, isoleuclne- and valine-derived carbon into triglycerides were measured in tissues from both normal and PCS-ratg. Apart from the differences in $\mathrm{Km}$ of $\mathrm{BCOA}-\mathrm{DH}$ for the three $B C A A$, different levels of incorporation of BCAA-derived carbon into triglycerldes will undoubtedly be influenced by the different degradation routes of the BCAA (for degradation routes of BCAA see addendum), distal of the oxidative decarboxylation and the subsequent partial $\beta$-oxidation step. 
Leucine degradation results in the inmediate formation of acetyl-Cod, the direct precursor in fatty acid synthesis, and in acetoacetate. The latter is readily converted to acetyl-CoA, and thus will also participate in fatty acid synthesis. Degradation of isoleucine, which is ketogenic and glycogenic, results in acetyl-CoA, ready for use in fatty acid synthesis, and, via propiony $1-C o A$, in succinyl-CoA, which can enter the tricarboxylic acid cycle to be converted to oxaloacetate. Oxaloacetate is part of the most important anaplerotic reaction of the tricarboxylic acid cycle, catalyzed by the mitochondrial enzyme, pyruvate carboxylase. In animal tissues, pyruvate may be carboxylated to produce more oxaloacetate whenever the tricarboxylic acid cycle is deflcient in oxaloacetate or its precursors. Conversely, when oxaloacetate is in excess, it is disposed of by reversal of this reaction. The pyruvate so formed, can then be oxidized to completion wia the cycle (via acetyl-CoA) but may also be used for fatty acid synthesis after being transported to the cytoplasm. Fatty acid synthesis from acetyl-CoA, derived from degradation of the glycogentc valine (via succinyl-CoA), is dependent on the same cumbersome pathway. Succinyl-CoA and oxaloacetate which originate from isoleucine and valine, may stimulate the tricarboxylic acid cycle, be oxidized to $\mathrm{CO}_{2}$ in the cycle or used for fatty acid synthesis. Acetyl-CoA, formed from labeled BCAA, mixes with the total acetyl-CoA pool. This labeling will be lower with isoleucine and valine, than with leucine. Therefore, a lower level of incorporation of isolewcine-derived carbon and still lower levels for valine-derived carbon into triglycerldes, compared with leucine-derived carbon, may be expected.

The decrease in incorporation of leucine- and isoleucine-derived carbon. into phospholipids after PCS ( $f \mathbb{1 g}, 3 a$ and $3 \mathrm{~b}$; no significance was reached for valine) may be explained by the diminished amount of membrane per fat-cell after PCS (smaller fat cells). This explanation assumes, however, that phospholipid turnover is not increased after PCS, which is not proven.

In vivo, the catabolism of a single amino actd will be influenced by several regulatory substances. Leucine has been indicated as one of these regulators $(1,4,5,6)$. The increased in witro $\mathrm{CO}_{2}$-production from ${ }^{14} \mathrm{C}-(1)$ valine and the increased incorporation in vitro of ${ }^{14} \mathrm{C}-(\mathrm{U})$-isoletucinederived carbon into triglycerides in the presence of unlabeled leucine 
(f1g. 1 and fig. 4) support such a regulatory function of leucine in adipose tissue from both normal and PCS rats. The maintained level of Incorporation of ${ }^{14} \mathrm{C}$-(U)-valine derlwed carbon into triglyceride in the presence of unlabeled leucine, may be interpreted as an increased incorporation. Competition between valine and leucine for the rate-limiting BCOA-DH would have resulted in a decreased incorporation of degradation products of the labeled substrate $\left({ }^{14} \mathrm{C}-(U)-v a l i n e\right)$ in the presence of leucine. This stimulatory effect may be explatined by an increased avallability of substrate (acetyl-CoA) as a consequence of increased decarboxylation of valine in the presence of leucine (fig. 1), probably by activation of the BCOA-DH by leuctne. Our findings are in agreement with the increased oxtdation of ${ }^{14} \mathrm{C}-(1)$-valine and ${ }^{14} \mathrm{C}-(\mathrm{U})$-isoleucine in the presence of leucine in adipose tissue segments from normal rats, as reported by Frick and Goodman (4). Conversely, leucine oxidation was not stimulated in the presence of valine, a result that was also obtalned in our laboratory (data not shown).

Irreversible decarboxylation of leuctne and valine in adipose tissue, both increased after PCS, occurs at different rates, albeit of the same order of magnitude. Even after stimulation of the irreversible decarboxylation of valine in the presence of leucine approximately equal rates are not reached. $\mathrm{CO}_{2}-$ Production in adipose tissue from the three universally labeled BCAA are also in the same order in both PCS- and sham-operated rats. The greatest differences between the BCAA in recorded parameters were seen in the incorporation of BCAA-derived carbon into fat. These differences were malntained after stimulation in the presence of leucine. All these smaller or greater differences make, however, that equal rates of catabolism of all three BCAA, could not be demonstrated. This ralses the question if the in witro recorded elevations in catabolism of the BCAA in adlpose tissue of PCS rats may in vivo be responsible for the observed decreases in plasma BCAA levels, each BCAA being decreased with about the same percentage. However, the approximately equal tncrease in the ability to decarboxylate BCAA in adipose tissue, may be expected to be of greater importance for the decrease of BCAA in plasma after PCS, than the absolute rates of BCAA degradation. Differences in absolute rates of BCAA degradation are also seen in normal rats with normal BCAA levels. Different 
$K_{\mathrm{m}}$-values of the $\mathrm{BCOA}-\mathrm{DH}$ for the $\mathrm{BCA}$ may, at least partilally, be responsible for this. The observed differences with especially valine may, in addition, partially be caused by the fact that we used a relatively low concentration $(0.1 \mathrm{mM}$ ) compared with normal valine plasma levels (ca. 0.15 mM). Besides the influence of leucine, other regulatory mechanisms in BCAA-catabolism will exert their influences simultaneously, especially in yivo. The role that adipose tissue may play in the catabolism of BCAA under non-pathological conditions is still often neglected. After PCS, adipose tissue seems to play an even more accentuated role evidenced by increased irreversible decarboxylation of $\mathrm{BCAA}$, as measured for leucine and valine.

This study supports the view that the increased catabolista of BCAA after PCS may contribute to the decreased plasma BCAA levels in PCS animals.

\section{References}

1. Buse MG, Reid SS: Leucine: a possible regulator of protein turnover in muscle. J Clin Invest 56: 1250-1261, 1975.

2. Burton K: A study of the conditions and mechanism of the diphenylamine reaction for the calorimetric estimation of deoxyribonuclelc acid. Biachen J 62: 315-323, 1956.

3. Fernstrom JD, Wurtman RJ, Hammerstrom-Wiklund B, et al: Diurnal varlations in plasma neutral anfno acid concentrations among patients with cirthosis: effect of dletary protein. An J Clin Nutr 32: 1923-1933, 1979.

4. Frick GP and Goodman HM: Regulation of branched chain a-keto acid dehydrogenase by insulin and leucine. In: Walsher M and Williamson JE (eds): Metabolism and clinical implications of branched chain amino and keto acids. Elsevier North-Holland, New York, p. 73-78, 1981.

5. Fulks RM, Goldberg AL: Effects of insulin, glucose and amino acids on protein turnover in rat dlaphragm. I Biol Chen 250: 290-298, 1975.

6. Odessey $R$, Khairallah EZ, Goldberg A: Origin and possible signiflcance of alanine production by skeletal muscle. I Biol Chem 249: 7623-7629, 1975.

7. Rafael $J$ and Vslansky P: Quantitative determitition of nucleic aclds in brown and white adipose tissue. Ann Blochem 115: 158-162, 1981 .

8. Rosenthal J, Angel A and Farkas J: Metabollc fate of leucine: a significant sterol precursor in adipose tissue and muscle. Aril J Physiol 226: 411-418, 1974 .

9. Tischler ME and Goldberg AL: Leucine degradation and release of glutamine and alanine by adipose tissue. I Blol Chem 255: 8075-8081, 1980 . 


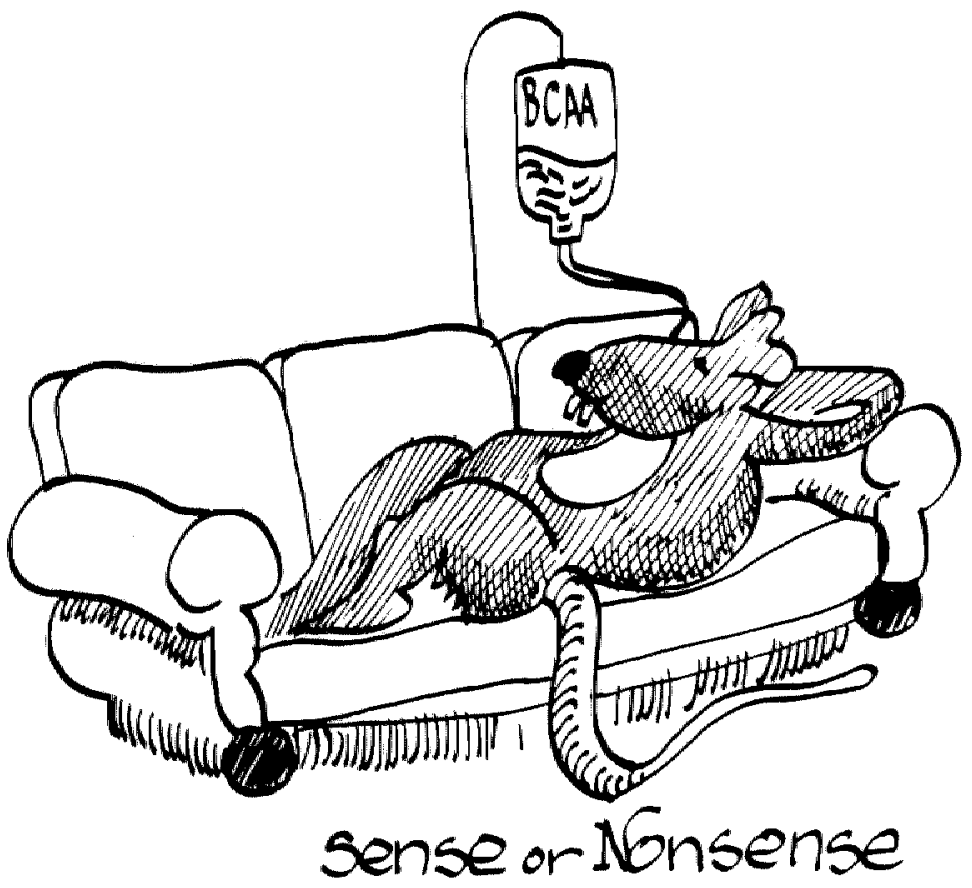


CHAPTER V

ACTIVITY OF BRANCHED CHAIN OXO ACID DEHYDROGENASE (BCOA-DH) IN ADIPOSE TISSUE AND DIAPHRAGM OF RATS: THE INFLUENCE OF PORTA-CAVAL SHUNT (PCS)

Suminary

Porta-caval shunting (PCS) in man and experimental andmals is accompanied by mildly elevated insulin levels and decreased branched chain amino acid (BCAA) levels in plasma from both overnight-fasted and fed subjects. In earlier experiments, we reported an increased catabolism of all three branched chain amino acids in adipose tissue of PCS-operated rats. In muscle, the catabolism of BCAA was not altered by PCS or was even decreased. Degradation of BCAA in muscle and adipose tissue from normal rats is limited by the activity of the branched chaln oxo acid dehydrogenase (BCOA-DH; EC 1.2.4.4.). From these observations, an increased activity of BCOA-DH in adipose tissue from PCS-operated rats was suggested. In order to test this hypothesis, we determined in vitro the activity of $B C O A-D H$ in muscle (diaphragm) and epididymal adipose tissue from fed PCS-operated rats and unoperated controls using a-ketolsocaproic acid $(a-k I C A)$ as substrate. In adipose tissue of PCS-operated rats, the BCOA-DH

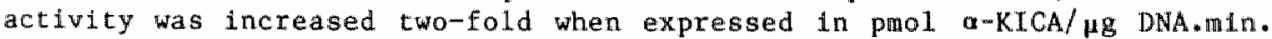
In contrast, diaphragm of PCS rats exhibtted a small decrease in BCOA-DH activity when expressed per $\mu g$ DNA. These results confirm an important role of adipose tissue in BCAA-catabolism after PGS and suggest that adlpose tissue causally contributes to the decreased plasma levels of BCAA after PCS. Short-term stimulation of BCOA-DH activity by insulin, as reported in the literature, was confirmed in adipose tissue from both normal and PCS-operated rats and seems to be superimposed on the stimulation of the BCOA-DH activity due to PCS, most probably caused by a long-term influence of insulin.

Introduction

Porta-caval shunting (PCS) in patlents and experimental animals $(2,6,20,22)$ leads to hyperinsulinism and decreased plasma levels of 
branched chaln anino acids (BCAA). Increased catabolism of BCAA in vitro in adpose tissue from overnight-fasted and fed rats with PCS was reported in chapter III and IW. In vitro BCAA catabollsm was approximately equal in muscle from PCs-operated and from sham-operated rats. Therefore, adipose tissue seemed primarlly responsible for the increased BCAA-catabolism in vivo after PCS.

Theoretically, there are at least three possible explanations for an increased processing of $B C A A$ in adipose tissue:

1. An Increased transport of $B C A A$ and/or $B C O A$ into the cell might be $a$ simple explanation but assumes that this transport is rate-1imiting. Transport of BCAA and BCOA across cell membranes does not occur by passive diffusion in contrast to $e . g$. that of pyruvate, but is mediated by transport systems as evidenced by specific inhibitors of the latter $(9,10,16,32,34)$. However, no support could be found in the 1lterature for a rate limting transport of BCAA andor BCoA, influencing BCAA-metabolism in peripheral tissues ( 12 ).

2. A second possibility would be a regulation at the receptar or postreceptor level. Using clamp techniques, insulin insensitivity has been reported in cirrhosis (23). There are some reports that suggest that the number of functional receptors for insulin is dininished in liver cirrhosis (1). However, such alterations would cause decreased metabolism of BCAA (23) and favour increased plasma BCAA levels.

3. Increased BCAA-catabolism in adipose tissue may be due to an increased enzymatic activity, possibly under hormonal influence or induced by increased substrate flow in coupled reactions (e.g. increased removal of glutamate by amonia).

The first step in the degradative pathway of BCAA is the transamination of the amino group to a-ketoglutarate. Products of this reaction are glutamate and the corresponding branched chain a-keto actds: $\alpha$-ketoisocaproic acid (ketoleucine), a-keto o-methylvaleric acid (keto-isoleucine) and a-ketoisovaleric acid (ketovaline). The second step in the degradation of BCAA is the oxidative decarboxylation of the $B C O A$, coupled to the reduction of $\mathrm{NAD}^{+}$ and the binding of coenzyme $A$ to form the corresponding branched chain thio-esters. While the first step, the transamination, is rate limiting in liver (37), the second step has been proven to be rate limiting in muscle and adipose tissue $(5,11,29)$. 
This study was undertaken to investigate the increased BCAA-catabollsm In vitro in peripheral tissues, i.e. adipose tissue, from Pcs-rats. Because changes in transport of BCAA and/or BCOA and altered tissue sensitivity (changes at the receptor level) are unlikely to be the cause of the increased BCAA-catabolism, we explored, in vitro, the influence of PCS on the activity of the rate-1imiting enzyme in BCAA catabolism in muscle and adipose tissue, the branched chain aminoacid dehydrogenase (BCOA-DH; EC 1.2.4.4.). a-Ketoisocaproic acid was used as substrate. BCOA-DH activity in adipose tissue from normal rats can be influenced in vitro by insulin $(7,12)$. We therefore also determined the activity of this enzyne, in tissues from both PCS-operated and sham-operated rats after preincubation with insulin. Any differences abserved should be ascribed to short-term influence of insulin and may be additive to long-term effects of insulin on the $B C O A-D H$ activity in tissues from PCS rats. On the other hand, it is possible that the short-term influence of Insulin on the enzymatic activity in tissues from PCS-rats appears less or absent, when the same stimulus is responsible for both long-term and short-term effects and stimulation is maximal after long-term stimulation.

\section{Materials and methods}

PCS- and sham-operations were performed in male sprague-Dawley rats weighing about 250 grams. Rats used in the experiment were selected according to criterla described earlier (chapter II). All pcs-operated rats exhibited, $2 \frac{1}{2}$ weeks post-operatively, hyperinsulinism, decreased plasma BCAA levels and had gained weight for at least one week. Two-and-a-half weeks after the operation, the diaphragm and epldidymal adipose tissue were quickly removed from the rats (in fed state) and used immediately for the determination of the activity of the branched chain oxo acid dehydrogenase $(\mathrm{BCOA}-\mathrm{DH} ; \mathrm{EC} 1 \cdot 2 \cdot 4 \cdot 4 \cdot)$.

Determination of $\mathrm{BCOA}-\mathrm{DH}$ activity

BCOA-DH activity was measured in tissue segments of diaphragm (approximately $50 \mathrm{mg}$ ) and epididymal adipose tissue (approxlmately $100 \mathrm{mg}$ ), 
that were incubated in a shakerbath at 60 cycles per minute at $38.5^{\circ} \mathrm{C}$. The incubation medium consisted of $\mathrm{Tr}$ is-HCl buffer (Tris (hydroxymethyl) amino methane: $75 \mathrm{mM}$ ) pH 7.4 at $38.5^{\circ} \mathrm{C}$ and contalned $3.3 \mathrm{mM} \mathrm{CaCl}_{2} .2 \mathrm{H}_{2} \mathrm{O}, 5$ mM $\mathrm{MgSO}_{4} \cdot 7 \mathrm{H}_{2} \mathrm{O}, 5 \mathrm{mM} \mathrm{NaHCO}_{3}, 5 \mathrm{mM}$ glucose and 75 mM sucrose. The tissues segments were preincubated in $1 \mathrm{ml}$ of this sixture. After 30 minutes, the tissues were transferred to $1 \mathrm{ml}$ fresh incubation medium containing 3.18 m $\mathrm{NAD}^{+}$and $1.15 \mathrm{mM}$ coenzyme $\mathrm{A}$ in addition to the consistuents mentioned. above. The reaction was started by addition of $50 \mu 16.42 \mathrm{mM}$ a-keto $\left(1-{ }^{14} \mathrm{C}\right)$ isocaprolc acld (a-KICA; s.a. $65 \mu \mathrm{Cl} / \mathrm{mol}$ ); consequently the concentration in the reaction vessel was $0.31 \mathrm{mM}$. The a-KICA-sodium salt was purchased from Amersham International, Amershan, Buckinghamshire, England, with a s.a. $5.4 \mathrm{mCl} / m$ mol. Nonspecific radioactivity was lowered by flushing the labeled a-KICA solution with nitrogen to remove labeled $\mathrm{CO}_{2}$. After 15,30 , 45 or 60 minutes incubation at $38.5^{\circ} \mathrm{C}$ in a shakerbath, the reaction was stopped by injection of $3 \mathrm{ml} 0.66 \mathrm{M}$ citric acid into the closed reaction vial. Subsequently, $0.33 \mathrm{ml}$ Solvene $\mathrm{R}^{\mathrm{R}}-100(0.5 \mathrm{~N}$ quaternary ammonium hydroxide in toluene; Packard Becker BV, Chemical Operations, Groningen, The Netherlands) was infected through the rubber stopper into the hanging center well (fixed to the stopper) to bind all the $\mathrm{CO}_{2}$ released by the reaction medium at low $\mathrm{pH}$. To be sure that all released $\mathrm{CO}_{2}$ was collected in the center well, the reaction vial was placed back into the shakerbath for one hour. Thereafter, the stopper plus fixed center well was carefully removed, the outer surface of the center well was dried and the center well transferred to a counting vial containing $1 \mathrm{ml}$ ethanol. After addition of $10 \mathrm{ml}$ counting solution (Atomlight ${ }^{\mathrm{R}}$, New England Nuclear), the radioactivity was measured in a liquid scintillation counter for 5 minutes. keaction velocities of $\mathrm{BCOA}-\mathrm{DH}$ were derived from time-curves of at least three time points and corrected for blank values, derived from reaction vials that contalned all constituents except tissue. All measurements were done $1 \mathrm{n}$ triplicate. Results were ploted in cpm/50 mg wet tissue weight for diaphragm and in cpm/100 mg for adipose tissue, to check linearity with time. The slopes of these curves represent the reaction velocities and were corrected for tissue DNA content. Final results were expressed in pmol $\alpha-\mathrm{KICA} / \mu \mathrm{g}$ DNA.min.

Tissue DNA content was determined in adipose tissue according to Rafael et al (35) and in diaphragm according to Burton (3). When 1nsulin was 
present during the (30 minute) preincubation of adipose tissue before recording the $\mathrm{BCOA}-\mathrm{DH}$ activity, the insulin concentration was $1 \mathrm{mil} / \mathrm{mil}$. Insulin was obtained from Novo Industrie BV Amsterdam (Actrapid ${ }^{R}$ ), 40 I.U./ml.

\section{Results}

Influence of PCS on BCOA-DH activity

BCOA-DH activity was measured in diaphragin and epididymal adipose tissue from 13 pCs-operated rats and 12 sham-operated controls. Tissues were taken from fed rats. The curves from which the reaction velacities were calculated after correction for tissue DNA content, are given in fig. 1 (diaphragm) and fig. 2 (adipose tissue). Fig. 1 demonstrates that,

\section{BCOA-DH}

in diaphragm
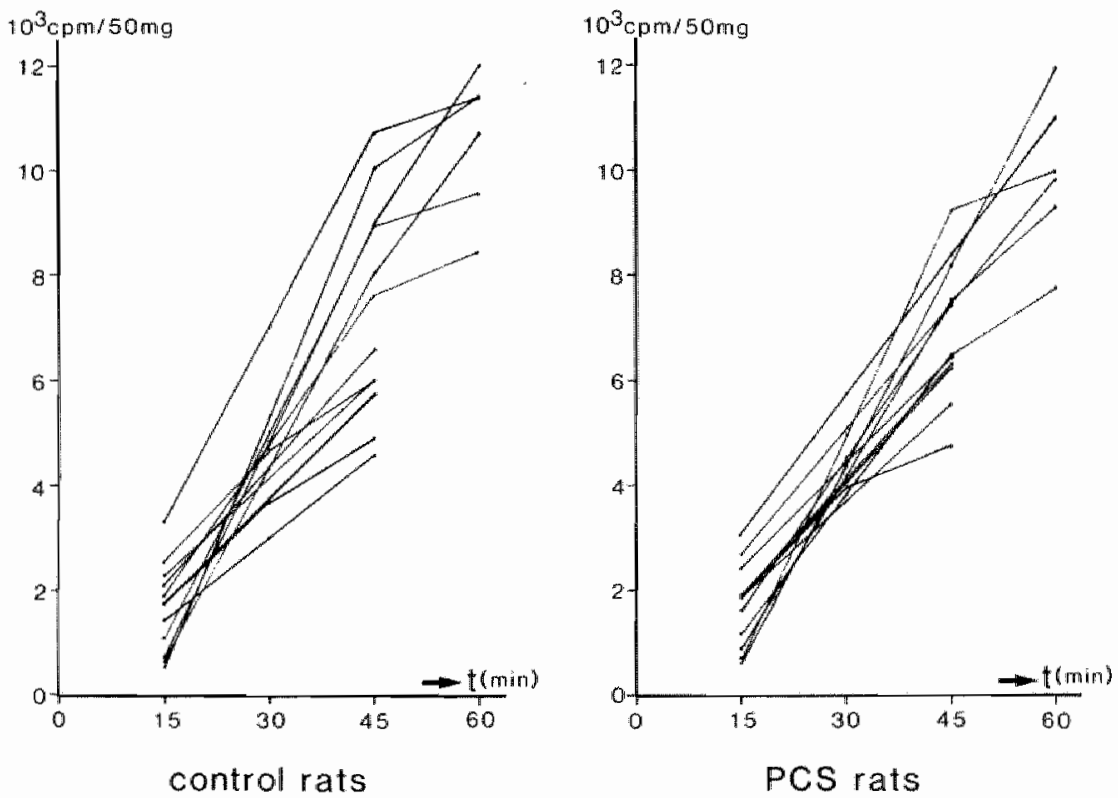

Figure 1

BCOA-DH activity in diaphragm from PCS-operated rats $(\mathrm{n}=13)$ and sham-operated controls $(\mathrm{n}=12)$ in the absorptive state. Each time-point was determined in triplicate. Data are expressed as cpm/50 $\mathrm{mg}$ wet tissue weight. For conditions usied, see 'Materials and methods'. 


\section{$\mathrm{BCOA}-\mathrm{DH}$ \\ in epididymal adipose tissue}
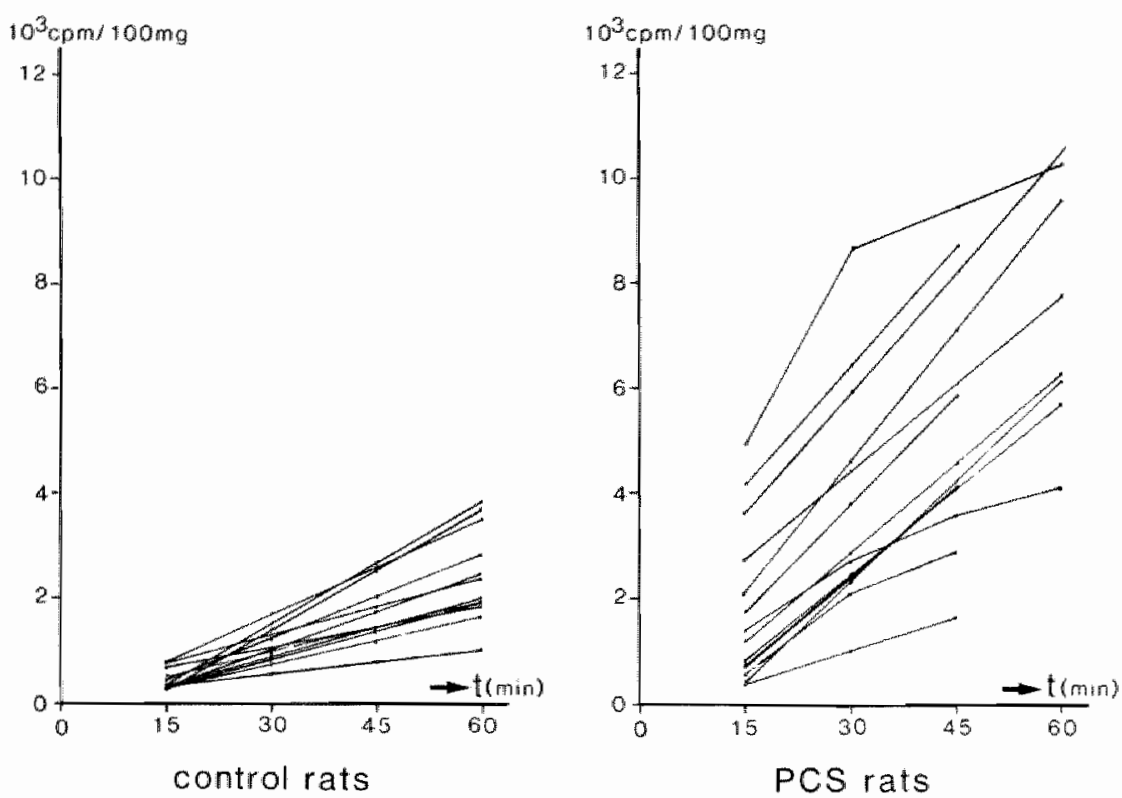

Figure 2

$\overline{B C O A-D H}$ activity in epididymal adipose tissue from PCS-operated rats $(\pi=13)$ and sham-operated controls $(n=12)$ in the absorptive state. Each time-point was determined in triplicate. Data are expressed as cpo/ 100 mg wet tissue weight. Conditions used are described in 'Materials and methods".

under the described conditions, BCOA-DH activity in diaphragm is linear up to $45 \mathrm{~min}$. When linearity was not maintained, the slope of the initiall part of the curve was taken for further calculations. The same procedure was used for adipose tissue (fig. 2), where BCOA-DH activity was linear up to 60 min in tissues from all rats used, except in three pCs-operated rats. Higs. 1 and 2 indicate that BCOA-DH activity, as measured under the conditions described, was linear between 15 and 45 minutes after initiating the reaction with $a-k I C A$ in almost all rats used. It is further demonstrated that BCOA-DH activity in adipose cissue from PCS-rats is increased compared with sham-operated controls, while BCOA-DH activity in diaphragm is approxinately similar in both groups. The data from figs. 1 


\section{BCOA-DH \\ IN ADIPOSE TISSUE}

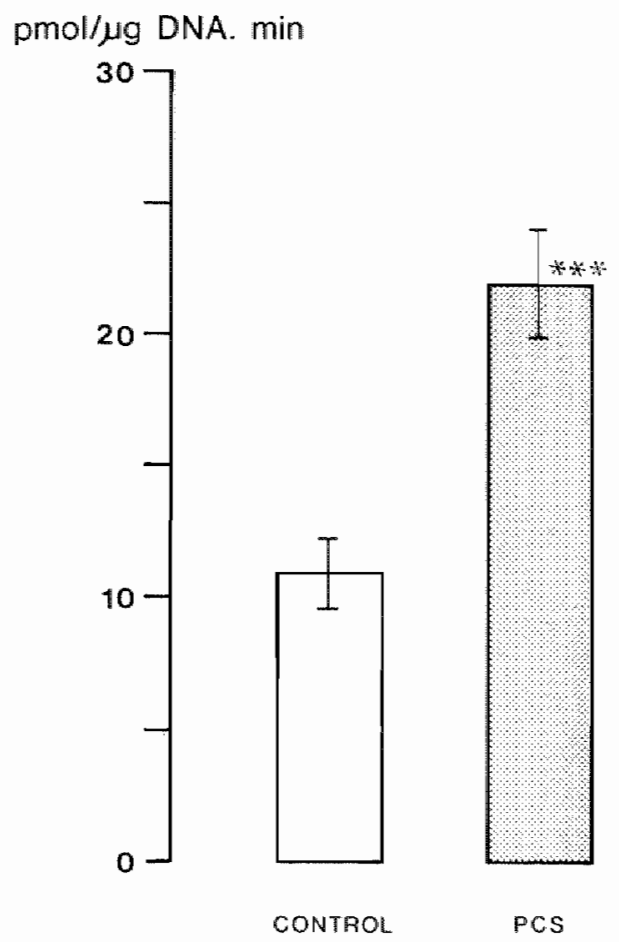

fed rats

substrate: ${ }^{14} \mathrm{C}-(1)-(\mathrm{KICA}(0.31 \mathrm{mMN})$

* compared with sham operated cartrols

$x+0.001$

Figure 3

BCOA-DH activity in epididymal adipose tissue from PCS-operated rats ( $\mathrm{n}=13$ ) and sham-operated controls $(n=12)$. Results are expressed in pmol a-KICA/ $\mathrm{g}$ DNA.min (mean \pm sem). Data were derived from fig. 2 .

and 2 were corrected for tissue DNA content of the individual rats and expressed in pmol a-KICA/ $\mu \mathrm{g}$ DNA.min (figs. 3 and 4). The results shown in fig. 3, demonstrate that, also after correction for tissue DNA content, the activity of $\mathrm{BCOA}-\mathrm{DH}$ in adipose tissue is stll significanty increased 


\section{BCOA-DH}

\section{IN DIAPHRAGM}

pmol/ug DNA. min

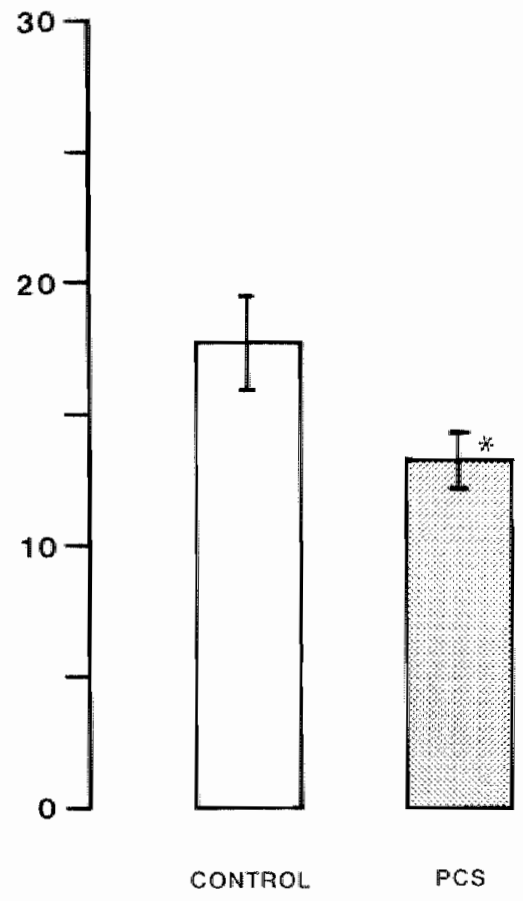

ted rats

$$
\text { substrate: }{ }^{14} \mathrm{C}-(1)-\mathrm{K} \text { KICA }(0.31 \mathrm{~mm})
$$

* compared with sham-operalled contrals $x=p<0.05$

Figure 4

BCOA-DH activity in diaphragm from PCS-operated rats $(n=13)$ and sham-operated controls $(n=12)$. Data were derived from $f 1 g$. 2. Results are expressed in pmo1 a-KICA / $\mu \mathrm{g}$ DNA.min (mean \pm sem).

after PCS $(p<0.0005)$. In contrast, the BCOA-DH activity in diaphragm (fig. 4) was decreased in the PCS group ( $p<0.05$ ) when DNA correction was carried out. 
$\mathrm{BCOA}-\mathrm{DH}$

in epididymal adipose tissue

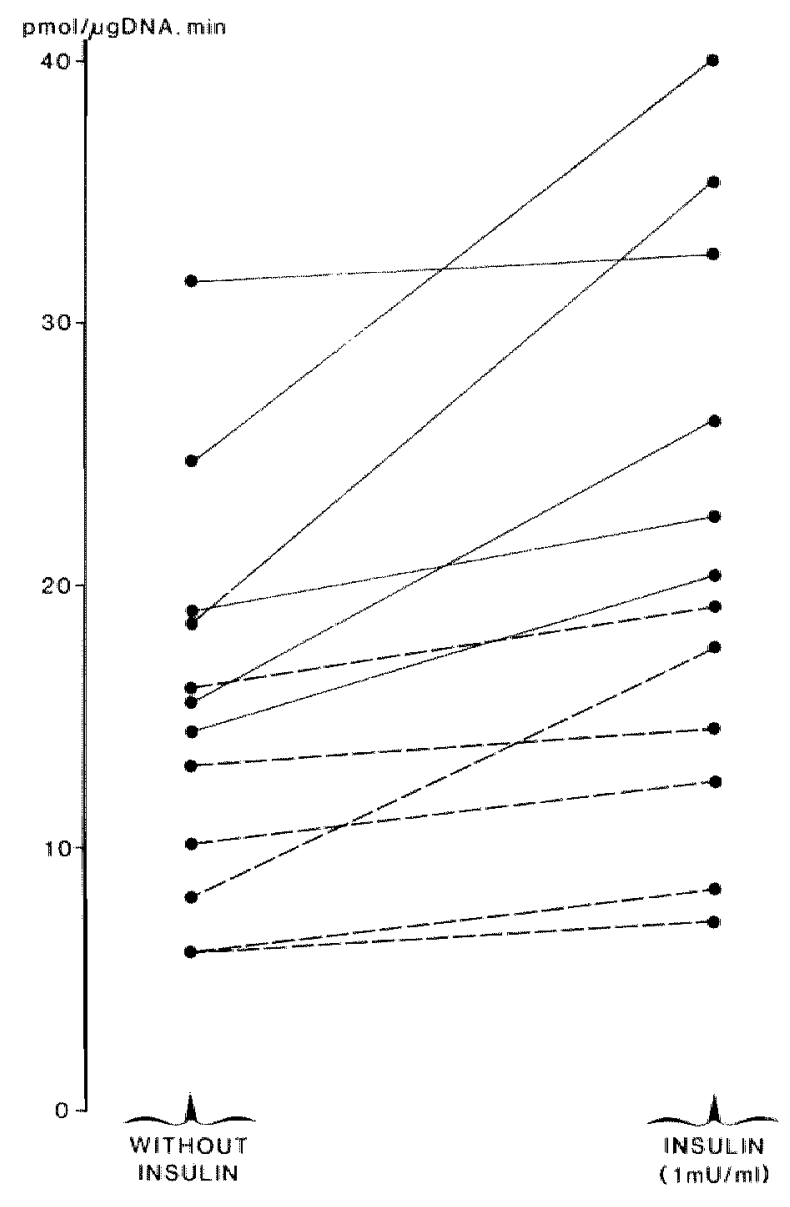

Figure 5

Short-term influence of insulin on the BCOA-DH activity in epididymal adipose tissue from PCS operated rats $(n=6$; solid 11nes) and sham-operated controls $\left(\mathrm{n}=6\right.$; broken lines) after $30^{\prime}$ preincubation with insulin ( $\left.1 \mathrm{mU} / \mathrm{m} 1\right)$. Regults are expressed as pmol a-KICA / $\mu g$ DNA.min. All these rats were part of the study in which long-term influence of PCS was measured.

\section{Short-term influence of insulin}

In 6 PCS-operated rats and 6 sham-operated rats, used in the experitment described above, the in vitro $\mathrm{BCOA}-\mathrm{DH}$ activity in adipose tissue was also recorded after a preincubation of 30 minutes in the presence of $1 \mathrm{nsu} 1 \mathrm{In}(\mathbb{1}$ 
mU/mil). Data were processed in the same way as described above. The final results are presented in fig. 5. Preincubation with insulin stimulates in Witro BCOA-DH activity in adipose tissue from both PCS-operated and control rats. Stimulation varles greatly but seems to be more pronounced in tissues from PCS rats. Short-term influence of insulln on BCOA-DH activity in diaphragm (data not shown) could not be demonstrated.

\section{Discussion}

In chapters III and IV, we reported an increased in vitro catabolism of BCA in adipose tissue from rats wh a PCS. The demonstration of an increased activity of the rate-limiting enzyme in BCAA-degradation, BCOA-DH, in adipose tissue of PCS-operated rats is in accordance with these findings. After correction for tissue DNA content, the activity of BCOA-DH in adipose tissue after PCS was increased by twofold. In contrast, dlaphragm exhibited in vitro a stgnificant decrease in BCOA-DH activity after PCS, when results were expressed per $\mu g$ DNA. These results emphasize the important role of adipose tissue in BCAA catabolism, especially after PCS, and suggest a role for adipose tissue in the decrease of BCAA levels in patients and experimental animals with liver insufficiency and/or portal-systemic shunting.

$B C O A-D H$ is a membrane-bound enzyme located at the inner surface bf the mitochondrial membrane (24). When measuring the enzynatic activity in tissue segments, one must keep in mind that the recorded activity may be submaximal due to the influence of membrane barriers, mediation by receptors, himitations in diffusion of substrate and the presence or absence of endogenous cofactors, activators, inhfbitors, suppressors, etc. Despite all these possible influences, we decided to perform the activity measurements in whole tissue segments because this may resemble the physlologlcal situation better than experiments with e.g. isolated or sonicated mitochondrla. Furthermore, the obtained data are more comparable with the results from the BCAA-catabolism studies, performed in in vitro Lncubation experiments with tissues from normal and PCS-operated rats (chapters III and IV). We wanted the tissues from PCS rats to maintain, as 
much as possible, the properties induced by the PCS-operation.

other findings that, in addition, led us to our decision to use whole thssue instead of tissue homogenates or partly purifled enzyme fractions, are now discussed. First of all, homogenizing had different effects on the $\mathrm{BCOA}-\mathrm{DH}$ activity in different tissues. While the activity in liver greatly increased during homogenization, which is in accordance with data from May and associates (25), activity in muscle decreased with a variable percentage, and in adipose tissue, hardly any activity was maititined. Different conditions were used (e.g. different types of homogenizers, time of homogenting, ultrasonic treatment, temperature, buffers, presence of glucose, sucrose, detergents, etc.) but no reproducible results could be obtained. Especially, no fixed ratio could be obtained between the activity present in the preparations and the activity measured in fresh whole tissue. Furthermore, the activity of the enzyme was often not high enough to guarantee reliable measurements. Detergents (Triton $X-100(0.02-1 \%)$ and CHAPS (3- ( (3 cholamidopropyl) dimethylamonio)-1-propanesulfonate; 0.02-1\%) decreased the activity in liver homogenates, had no effect or decreased the activity even further in muscle homogenates ( $1 \%$ detergent) and had no effect at all in adipose tissue homogenates. Conflicting data with respect to BCOA-DH activity after homogenization and the use of different buffers and detergents have also been reported in the literature for different tissues (39). From adipose tissue we also prepared fat-poor homogenates (26), but, besides loss of activity due to homogenization, variable percentages of activity were lost by being trapped in the floating fat-mass which, moreover, is extremely difficult to handle.

Freezing of all tissues or tissue homogenates decreased the BCOA-DH activity further, if it had been detectable at all, as often occurred in. adipose tissue homogenates. Freering of whole tissue had, like the homogenizing of muscle and adipose tissue, a deleterdous effect on the activity in these tissues. Loss of activity after freezing is also reported with variable results by others $(25,39)$. By freezing, the local concentration of endogenous cofactors and/or facilitators may have become deficient by disruption of the integrity of the tissue. Repletion af the tissue preparations with these factors, absent in the reaction medium described, did not restore the enzymatic activity to levels recorded in fresh tissue segments. Mostly there was no measurable effect at all. 
Calcium and bicarbonate tended to increase any remalning activity in frozen and homogenized tissue preparations, but had a similar effect in fresh tissue segments, probably by Influencing membrane permeability. Addition of carnitine, ADP or thilanine pyrophosphate, singly or in combinations, to the reaction mixture, did not influence the activity of $B C O A-D H$ in fresh tissue segments of muscle and adipose tissue. Omitting $\mathbb{N A D}^{+}$or CoASH from the reaction mixture, supposing that endogenous amounts would suffice (25), decreased the activity that could be measured after 30 minutes, creating non-linear curves between 15 and 45 minutes. This observation seems paradoxical because the reaction takes place on the inner surface of the mitochondrial membrane, where the enzyme complex is located (24). This menbrane is impermeable to both $\mathrm{NAD}^{+}$and CoASH. Addition of NAD may facliftate the reaction by removing reducling equivalents generated in the mitochondria and transferred to the cytosol via the malate-aspartate shuttle. Calcium, present in the reaction vial, may alter the membrane permeability for $\operatorname{NAD}^{+}(15,19)$ and possibly also for COASH.

Before the enzymatic reaction was started by addition of a-KICA to the reaction vial containing buffer, tissue and co-enzymes, the tissues were preincubated in buffer without co-enzymes for 30 minutes. This procedure was chosen after it was observed that preincubation stimulated the activity in adipose tissue. The same procedure was used for diaphragm. In both tissues, the lag-time before reaching linearity with time, was shortened by this preincubation. On the other hand, If nearity in time was shortened from 60 and 90 minutes for muscle and adipose tissue, respectively, to 45 and 60 min.

In segments of dlaphragm from $200-350 \mathrm{~g}$ rats, activity increased linearly with tissue weight from 25 to $100 \mathrm{mg}$. In adipose tissue, linearity with respect to welght of the tissue segments ranged from about 50 to 200 ing in 200-400 g rats, but was clearly dependent on the size of the fat cells, exhibiting wore activity in leaner and younger rats.

The concentration of a-KICA $(0.31 \mathrm{mM})$, used in the BCOA-DH assay, is nearly optimal with respect to Vmax and is about 3-10 times the $\mathrm{Km}$ as reported $1 \mathrm{~m}$ preparations from rat liver, kidney, muscle and adipose tissue $(7,25,39)$. 
The increased $B C O A-D H$ activity in vitro in adipose tissue after PCS is in agreement with the increased BCAA-catabolism in vitro in adpose tissue of PCS rats, as reported before (chapters III and IV) and may contribute to the existing lowered plasma levels of the BCAA in vivo after PCS.

The results from $B C O A-D H$ activity measurements in dlaphragm from normal and PCS-rats, are also in agreement with the rates of BCAA-catabolism in the tissues of these rats, namely decreased BCAA catabolism and decreased BCOA-DH activity after PCS when expressed per $\mu \mathrm{g}$ DNA. In muscle and muscle preparations, $B C O A-D H$ activity is regulated by the ATP/AOP ratio influencing the ratio of inactive: active enzyme $(18,27,28,30,31)$. The activity is further reported to be influenced by carmitine (stimulation; ref. 38), branched chain fatty acids and actanoate (feed back linhibition via CoA esters), as well as by ingested protein and leuclne. Most of these factors may influence the rate of entry of BCAA into cells ard thus intracellular concentrations of BCAA. After transamination of the BCAA in rat muscle, a significant proportion of the newly formed BCOA is released into the extracellular space (21), 1.e. In the incubation medium, thereby maintaining low intracellular $\mathrm{BCOA}$ concentrations insufficient to saturate the BCOA-DH. After PCS, entry of BCAA into muscle may be lowered by decreased circulating plasma BCAA-levels, thereby, in addition, diminishing the stimulatory effect of leucine on BCOA-DH (4).

The mechanism by which the increased BCOA-DH activity in adipose tissue after PCS is induced, is difficult to assess. In the short term, the activity is reported to be influenced in vitro in adipase tissue or adipose tissue preparations by glucose (only in tissues from fasted rats; immediate effect), and by leucine and insulin within 30 minutes $(7,8,9,11,12)$. In the long term, BCOA-DH activity in adipose tissue is also influenced by fasting, starvation, malnutrition, protein content of diets and unsupplied streptozotocin-induced diabetes $(25,39)$. All these observations represent or simulate conditions that, in vivo, coincide with concomitant changes in insulin levels and plasma BCAA levels. This makes insulin a likely candidate to be involved in the increased BCOA-DH activity observed in adipose tissue from PCS rats, exhibiting hyperinsulinism and decreased plasma BCAA levels in both the fasted and fed state. In addition to the increased $B C O A-D H$ activity in adipose tissue after $\mathrm{PCS}$, a small and 
variable Eurther increase was measured after short-term preincubation with high dose lnsulin ( $1 \mathrm{mU} / \mathrm{ml}$ ) which 1 s suggested fron fig. 5 to be more pronounced in adipose tissue from PCS rats than in sham-operated controls. If we assume that this further stimulation has an equal effect in both groups, the results suggest that the increased activity following PCS (fig. 3), is due to an increased quantity of enzyme, rather than a difference in the amount of actlvated enzyme. Some uncertainty about a causal relationship between insulin and $\mathrm{BCOA}-\mathrm{DH}$ in adipose tissue remains. If insulin is instrumental, the greatest insulin effect, as after PCS, is under long-term regulation. The mechanism of action of insulin on BCOA-DH is completely unknown. Studies in which short-term influence by insulin on adipose tissue homogenates and whole tissue segments was explored $(8,12)$, suggest that insulin lowers the apparent $\mathrm{km}$ without affecting Vmax (which is suggested to be influenced by leucine). Long-term effects of insulin are probably mediated via enzyme synthesis, rather than via activation, and is possibly brought about by interference wth suppressors. Wohlhueter and Harper were unable to draw conclusions from their studies in liver preparations from normal rats with inhibitors of protein synthesis, because one of these inhibitors, cyclohexinide, had different effects on BCOA-DH activity after stimulation with leucine and with protein (39). However, different tissues may have different mechanisms of regulation of BCOA-DH activity. While BCAA, especially leucine, and protein seem to be comon inducing agents in liver, kidney, muscle and adipose tissue, insulin does not have a stimulatory effect in all these tissues, netther do fasting or low protein diet $(17,39,40)$. Insulin Increases $B C O A-D H$ activity 1 th adpose tissue $(7,11,12)$, but does not change or even decreases activity in muscle. Lack of insulin in unsupplied diabetes promotes BCOA-DH activity in liver (25) and decreases activity in adipose tissue (12; unpublished obserwation of our own group). In liver preparations, many other agents and conditions are reported to influence $B C O A-D H$ activity. It has been further reported that muscle may play a special regulatory role in the activity of BCOA-DH in other tissues by mediation of a still unrecognized factor, probably a peptide or protein, relleased by muscle (33). Cytosolic a-KICA-dehydrogenase activity as present in liver tissue $(13,14,25,36)$ (a-KICA specific, NAD $^{+}$ and CoA Independent and therefore called a-kICA decarboxylase) is reported not to be present in muscle or adipose tissue and is not relevant for the 
altered BCAA-catabolism in adipose tissue after PCS. In" wiek of the lack of effect of insulin on the BCOA-DH activity in muscle, it is unlikely that decreased BCOA-DH activity in diaphragu of PCS rats is caused by hyperinsulinfsm but may be related to lower food intake and less favourable growing curves in PCS rats.

\section{References}

1. Blei $A$, Robbins $D$ : Insulin resistance and insulin receptors in hepatic cirrhosis. Gastroenterology 83: 1191-1199, 1982.

2. Bloxam DL, Curzon G: A study of proposed determinants of brain. tryptophan concentration in rats after portacaval anastomosis or sham operation. J Neurochem $31: 1255-1263,1.978$.

3. Burton $\mathrm{K}$ : A study of the conditions and mechanism of the diphenylamine reaction for the calorimetric estimation of deoxyribonucleic actd. Biachem J 62: 315-323, 1956.

4. Buse MG, Reid SS: Leucine: A possible regulator of protein turnover in muscle. J Clin Invest 56: 1250-1261, 1975 .

5. Chang TW, Goldberg AL: The origin of alanine produced in skeletal muscle. J Biol Chem 253: 3677-3684, 1978.

6. Cummings MG, Soeters PB, James JH, et al: Regional brain indoleamine metabolism following chronic portacaval anastomosis in the rat. I Neurochem 27: 501-509, 1976.

7. Frick GP, Goodman HM: Insulin regulation of branched chain a-keto acid dehydrogenase in adipose tissue. J Biol Chem 255: 6186-6192, 1980.

8. Frick GP, Goodman HM: Regulation of branched chain a-keto acid dehydrogenase by insulin and leuclne. In: Walser $M$, Williamson JR (eds): Metabolism and clinical implications of branched chain amino and ketoacids Elsevier North-Holland, New York, p.73-78, 1981.

9. Goodman HM: Stimulatory action of insulin on leucine uptake and metabolism in adlpose tissue. Am J Physiol 206: 129-132, 1964.

10. Goodman HM: Alpha amino isobutyric acid transport in adipose tissue. An J Physiol 211: 815-820, 1966.

11. Goodman HM: Site of action of insulin in promoting leucine utilization in adiprose tissue. Am J Physiol 233: E97-E103, 1977.

12. Goodman H, Frick G: Metabolism of branched chaln amino acids in adipose tissue. In: Walser M, Williamson JR (eds): Metabollsm and clinical implications of branched chaln amino and ketoacids Elsevier North Holland, New York, p 169-180, 1981.

13. Grant WD, Conne1.1y JL: The detection and 1nvestigation of cytosolic branched-chaln a-ketoacid dehydrogenase. Fed Proc 33: 1570, 1974 .

14. Grant WD, Conne11y JL: Mamallan cytosolic a-ketoacid decarboxylase. Fed Proc 34: 640, 1975.

15. Greenspan MD, Purvis JL: The energy 11nked Incorporation of diphosphopyridine nucleotide into rat liver mitochondrla: Requirements for incorporation. J Biol Chem 243: 2921-2927, 1968. 
16. Halestrap AP: The mtochondrial pyruvate carrier. Kinetics and specifleity for substrates and inhibitors. Biochem $J 148: 85-96,1975$.

17. Hauschildt $S$, Brand K: Effects of branched-chain ketcacids on enzymes involved in branched-chain a-keto acid metabolism in rat tissues.

J Wuter 110: 1709-1716, 1980 .

18. Hugtes WA, Hallestrap AP: The regulation of branched-chain 2-oxoacid dehydrogenase of liver, kldney and heart by phosphorylation.

Biocherm J 196: 459-469, 1981.

19: Hunter DR, Haworth RA, Southard JH: Relationship between configuratlan, function and permeabillty in calcium-treated mitrochondria. $J$ Bio1 Chem 251: 5069-5077, 1976.

20. James JH, Hodgman JM, Funovics JM, et al: Braln tryptophan, plasma free tryptophan and distribution of plasma neutral amino acids. Metabolism 25: $471-476,1976$.

21. Livesey G, Lund $P$ : Enzymatic determination of branched-chain amino acids and 2-oxoacids in rat tissues. Transfer of 2-oxoacids from skeletal muscle to l1ver in viva. Biochem $J$ 188: 705-713, 1980.

22. Maddrey WC, Weber FL, Coulter AW, et al: Effects of keto analogues of essential amino acids in portal-systemic encephalopathy. Gastroenterology 71: 190-195, 1976.

23. Marchesint G, Bianchi G, Zoli M: Plasma amino acid response to protein ingestion in patients with liver disease. Gastroenterology 85: $283-290,1983$.

24. May ME, Aftring RP, Buse MG: Mechanism of the stimulation of branched chain oxoacid oxidation in liver by carnitine. $J$ Biol Chem 255: $8394-8397,1980$.

25. May MEE, Mancusi WJ, Aftring RP, et al: Effects of diabetes on oxidative decarboxylation of branched chain keto acids. Am J Physiol 239: E215-E222, 1980.

26. Mukherjee C, Jungas RL: Actlvation of pyruvate dehydrogenase in adipose tissue by insulin. Biochem J 148: 229-235, 1975.

27. Ddessey R: Reversible ATP-induced inactivation of branched chain 2-oxo acid dehydrogenase. Blochem $\mathrm{J} 192: 155-163,1980$.

28. Odessey R: Direct evidence for the inactivation of branched-chain oxo-acid dehydrogenase by enzywe phosphorylation. FEBS Lett 121: 306-308, 1980 .

29. Odessey $R$, Goldberg AL: Leuclne degradation in cell free extracts of skeletal muscle. Blochem J 178: 475-489, 1979.

30. Parker PJ, Randle PJ: Inactivation of rat heart branched chain 2-oxoacld dehydrogenase complex by ATP. FEBS Lett 95: 153-156, 1978.

31. Parker PJ, Randle PJ: Active and inactive forms of branched chain 2-oxoacid dehydrogenase complex in rat heart and skeletal muscle.

FEBS Lett $112: 186-190,1980$.

32. Potel TB, Waymark PP, Olson MS: The effect of the monocarboxylate translocator inhlbitor, a-cyanocinnamate, on the oxidation of branched chain a-keto acids in rat liver. Arch Biochem Biophys 201: 629-635, 1980.

33. Paul HS, Adibi SA: A possible role for the muscle in the regulation of oxidation of branched chain amino acid in the liver. In: Blackburn GL, Grant JP, Young VR (eds): Amino acids, metabolism and medical applications. John Wright, PSG Inc, Boston p. 191-199, 1983.

34. Pratt OE: The entry of amino acids into cells. In: Waterlaw JC, Stephen JML (eds): Nitrogen metabolism in man. Applied Science Publishers Ltd., Essex, England, p. 17-37, 1981. 
35. Rafael J, Vsiansky $P$ : Quantitive determination of nucleic acids in brown and white adipose tissue. Ann Blochem 115: 158-162, 1981 .

36. Sabourin PJ, Bieber LL: Formation of B-hydroxyisovalerate from a-ketoisocaproate by a soluble preparation from rat 1 iver. In: Walser M, Williamson JR (eds): Metabolism and clinical implications of branched chain anino and ketoacids. Elsevier North-Holland New York, p.149-154, 1981 .

37. Shinnick FL, Harper AE: Branched-chain amino acid oxidation by isolated rat tissue preparations. Blochim Biophys Acta 437: 477-486, 1976.

38. Van Hinsbergh VWM, Veerkamp JH, Engelen PJM, et al: Effect of L-carnitine on the oxldation of leucine and valine by rat muscle. Biochem Med 20: 115-124, 1978.

39. Wohlhueter RM, Haxper AE: Colnduction of rat liver branched chain a-keto acid dehydrogenase activities. J Blol Chem 245: 2391-2401, 1970.

40. Zapolowski $C$, Hutson SM, Harper AE: Effects of starvation and diabetes on leucine and valine metabolism in the perfused rat hindquarter. In: Walser M, Williamson JR (eds): Metabolism and clinical implications of branched chain amino and ketoacids. Elsevier North-Holland, New York, p. 239-244, 1981 . 
$-122-$

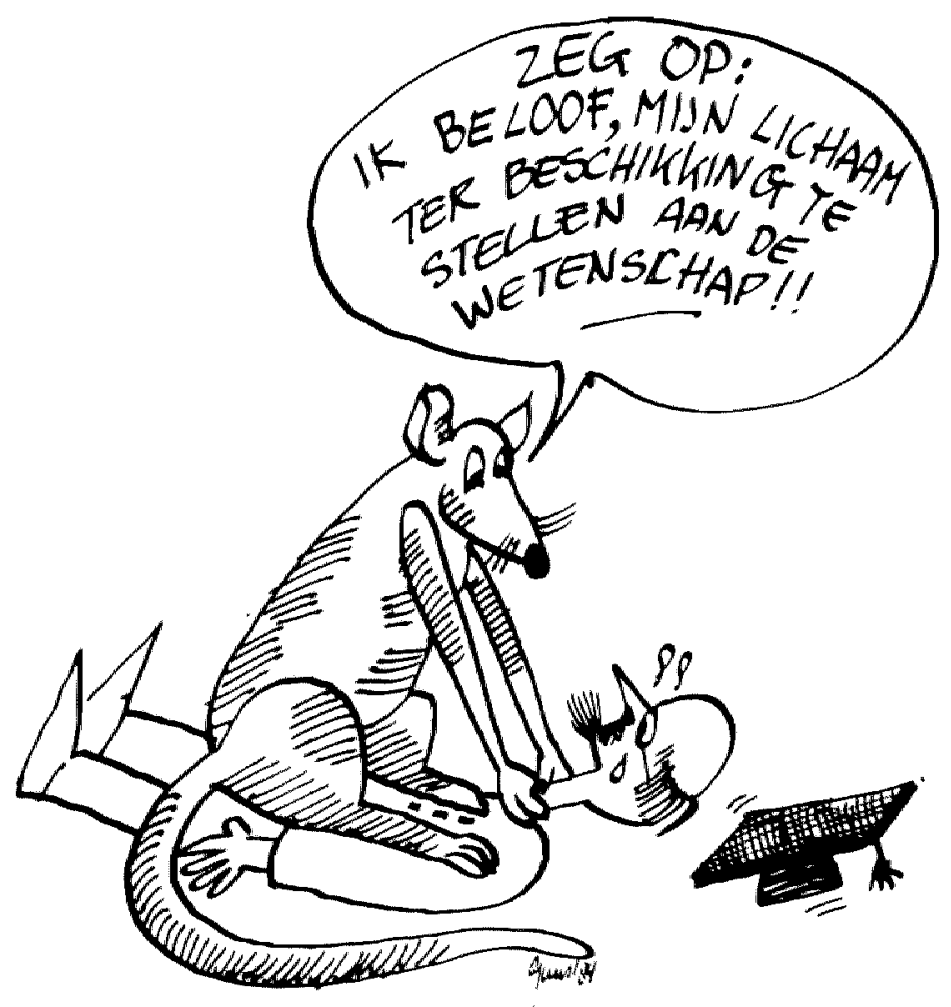




\section{GENERAL DISCUSSION}

In the preceeding chapters some aspects have been described of branched chain aminoacid (BCAA) metabolism in vitro in both muscle and adipose tissue from porta-caval shunt (PCS)-operated rats. Muscle and adipose tissue are quantitatively the most important sites of BCAA catabolism in the body. It has been shown that PCS itself can result in decreased levels of BCAA in plasma, also in the absence of accompanying superimposed disorders such as starvation, malnutrition, sepsis or serious liver fallure, that may otherwise exhibit additional influences on plasma BCAA levels. Therefore, observed alterations in BCAA metabolism must be due to the PCS. The animal model described, served in these studies as one in which there are decreased plasma BCAA levels in combination with hyperinsulinism, in the absence of the above-mentioned superimposed disorders. Consequently, we dealt with relatively healthy, growing animals. This does not mean that other abnormalities, encountered in liver insufficlency, were completely absent. Liver enzyme activities in plasma deviated slightly; moderate elevations of ALT, AST, AP and GLDH were observed. Generally, however, these abnormalities were mild, both after the shunt operation and at the time of the experiments, when compared with reports in the literature and with results from rats that had a PCS operation in our laboratory according to the classical "suture" technique. Furthermore, increased plasma glucagon, ammonia and AAA levels occurred in these PCS rats (chapter II). It needs to be emphasized ance more that, in spite of the observed mild disturbances in liver function, our "non-suture" PCS model, used according to the criteria described in chapter II, may not be considered as an antmal model for chronic liver fallure or hepatic encepha- 
lopathy. Chronic liver insufficlency develops during many years and this cannot be simulated in rats in two weeks or month. The PCS model, even when standardized as much as possible, is a variable model. Using only PCS rats fulfiling our criteria, $\mathbb{1}$ mplies that many rats that had a PCSoperation, could not be included in the studies. Only in this way could we be sure that the phenomena studied, resulted from the PCS itself rather than from secondary phenomena. The PCS rat model described, was used to obtaln muscle and adipose tissue which may be expected to exhibit metabolic characteristics, that are the consequence of PCS itself.

In vitro incubation studies, in which muscle and adipose tissue from PCS- and sham-operated rats were used, demonstrated that BCAA catabolisu in adipose tissue was increased after PCS. Th1s was evidenced by increased irreversible decarboxylation of leucine and valine. ${ }^{14} \mathrm{C}-(1)-\mathrm{L}$-Isoleucine was not avallable for our experiments, and thus irreversible decarboxylation of isoleucine could not be studied. The increased decarboxylation of BCAA In adipose tissue, due to PCS, may contribuce causally to the decreased plasma BCAA levels observed in PCS rats.

Increased decarboxylation of BCAA in adipose tissue after PCS, was accompanied by increased fatty acid synthesis and storage of BCAA-derived carbon into triglycerides. The levels of incorporation of BCAA-deriwed carbon into triglycerldes, decreased in the order leucine to isoleucine to valine (100\%, 50\%, and $10 \%$ resp.), in tissues from both PCS-operated rats and sham-operated controls. In addition, PCS resulted in increased combustion of valine-derlved carbon to $\mathrm{CO}_{2}$. This increase was not found with leucine and 1soleuctne. This $\mathrm{CO}_{2}$-production from universally labeled BCAA also decreased in the order leucine to isoleucine to valine in adipose tissue from both PCS-operated rats $(100 \%, 94 \%$, and $87 \%$ resp.) and sham-operated controls $(100 \%, 77 \%$, and $52 \%$ resp.). Furthermore, it was demonstrated that in adipose tlssue from both PCS- and control rats, all leucine and vallne that was decarboxylated, was used for elther fatty acid synthesis or was degraded to $\mathrm{CO}_{2}$. This indicates that other degradation pathways of BCAA in adipose tissue are negligible.

The differences in the levels of irreversible degradation of BCAA, of fatty acid synthesis and of combustion to $\mathrm{CO}_{2}$ of the rest of the carbon skeletons of BCAA, can be explained by different rates of transamination (different $\mathrm{Km}^{\prime} \mathrm{s}$ ), of oxidative decarboxylation (different $\mathrm{km}$ 's; stimulating 
effect of leucline on the activity of $\mathrm{BCOA}-\mathrm{DH}$ ) and by differences in the degradation routes of the BCAA (chapter 'IV; see addentum for degradation pathways of $B C A A)$. This results in different amounts of acetyl-CoA the direct precursor for fatty acid synthesis, while isoleuclne and valine degradation also yield tricarboxylic acid cycle intermediates. The different rates of decarboxylation of leucine, lsoleucine and valine in adipase tissues from both PCS operated and control rats, are not in conflict with a causal relationship in vivo between increased BCAA catabolism and decreased plasma BCAA levels after PCS. Different levels of degradation of BCAA in tissues from normal rats coincide with normal plasma BCAA levels. After PCS, the rates of decarboxylation of the BCAA appear to be increased to the same extent. This may explain the approximately equal decrease of BCAA levels in plasma after PCS.

Although adipose tissue was, in vitro, responsible for the increase in. BCAA degradation, in vitro metabolism in muscle was not completely unaffected. Irreversible degradation of $B C A A$ in vitro in muscle was not affected or was even decreased after PCS, but protein synthesis proved to be increased after PCS. Of course, increased protein synthesis results in an increased removal of BCAA from the incubation medium in vitro and from plasma in vivo, but, as pointed out before, the amount of BCAA required for protein synthesis is quantitatively less important wh respect to the total amount of BCAA that is catabolized. Furthermore, protein degradation occurs at the same time and replenishes intracellular free BCAA pools. Moreover, BCAA used for protein synthesis are not degraded. In contrast to the complete degradation of BCAA $\mathbb{I n}_{\text {adipose }}$ issue, it appears that after decarboxylation in muscle, a significant part of the carbon skeleton of BCAA is not degraded to $\mathrm{CO}_{2}$, indicating an incomplete combustion in muscle. Most probably these carbon atoms are used for synthesis of glutamine via a-ketoglutarate and glutamate.

In health and after PCS, about half of the BCAA are catabollzed in muscle, due to the total muscle mass and the activity of the rate limiting BCOA-DH in muscle. Decarboxylation rates did not consistenty change after PCS. This indicates that in vivo, muscle is unlikely to contribute to the decrease of plasma BCAA levels after PCS. Our results strongly suggest however, that adipose tissue, despite its smalier total mass in the body as compared with muscle, is concerned in the regulation of plasma BCAA levels. 
Futhermore, it should be realized that decarboxylation rates of BCAA are highest in adipose tissue and diaphragm and are much lover in skeletal muscle, when expressed per unit weight (chapter I). Generally, though, adipose tissue is still considered to be rather inactive and quantitatively unimportant in AA-metabolism.

As has already been mentioned, BCAA-catabolism in extrahepatic tissues is predominantly regulated by the activity of the BCOA-DH. This is supported by our findings that, after PCS, there is an increased activity of the enzyme in adipose tissue and a slightly decreased activity in muscle. These results were expected on the basis of the alterations in vitro in the degradation of BCAA after PCS.

In conclusion, adipose tissue has been indicated as an organ contributing to the lowering of plasma BCAA levels after PCS, and evidence 1s obtained that increased activity of $\mathrm{BCOA}-\mathrm{DH}$ in adipose tissue might be responsible for the increased BCAA catabolism. The next question to be answered 1s: what mechanism regulates $\mathrm{BCOA-DH}$ activity in adipose tissue after PCS? And further, is that mechanlsm limited to PCS or 1 it applicable to other disease states with altered plasma BCAA levels as well? pCs-operated animals and patients with surgical or spontaneous portal-systemic shunting exhibit, besides low plasma BCAA levels, hyperinsulinism and hyperglucagonism. A relationship between glucagon and BCAA has never been described, in contrast to one with insulin as discussed earlier (chapters $I, I I I$ and V). In our view, Insulin is the most likely candidate responstble for increased BCAA catabolism in adipose tissue after PCS. Many arguments support this view and many data are in agreement with this concept:

* Hyperinsulinism is present in our PCS animal madel and has been documented in experimental, surgical and spontaneous shunting (chapters I, II and III; 2,4).

* The increased activity of BCOA-DH in adipose tissue after PCS is in accordance with the in vitro demonstrated stimulation of this enzymatic activity by insulin $(5,6$, and chapter V).

* The unaltered or slightly decreased activity of BCOA-DH in muscle is in agreement with the fact that insulin does not stimulate this activity in muscle in vitro (chapter V). 
* The role of insulin is further supported by findings in other rat models with altered plasma insulin and BCAA levels (unpublished observations).

Unsupplied diabetes is accompanied by low insulin lewels, high BCAA levels, decreased catabolism of leucine in adipose tissue in vitro and decreased BCOA-DH activity in adipose tissue. Diabetic rats with a PCS exhibit plasma insulin levels that are lower than from PCS rats and even lower than from untreated controls, but higher than from unsupplied streptozotocin-induced dlabetic rats. The plasma BCAA levels in these rats are elevated but lower than from diabetics.

Rats fed with high protein diets for one week, have elevated Insulin levels and exhibit increased BCOA-DH activity in adipose tissue. In contrast, long-term starvation is accompanied by low insulin levels, low BCAA levels and low BCOA-DH activity in adipose tissue.

Non-obese Zucker rats have slightly lower insulin levels than normal Sprague-Dawley rats and exhibit slightly higher plasma BCAA levels and moderately decreased leucine catabolism in adipose tissue, suggesting decreased $B C O A-D H$ activity in adipose tissue.

obese zucker rats have, after feeding, highly elevated insulin levels, but exhibit insulin-resistance. These rats have, in the absorptive state, high BCAA levels and exhibit a decreased leucine catabolism in adipose tissue. Further support was derived from the extremely 10w BCOA-DH activities that we recorded in adipose tissue of obese patients (unpublished results).

In PCS rats, BCAA catabolism is increased even after an overalght fast (chapter III).

These findings suggest that insulin may also play a role in long-term regulation of $\mathrm{BCOA-DH}$ activity in adipose tissue. This supports an Inverse correlation between plasma insulin levels and BCAA levels mediated by $B C O A-D H$ activity in adipose tissue. These indicated relationships cannot be demonstrated in muscle of rats in a varlety of experimental conditions exhibiting chronic changes in the nutrittonal or hormonal state.

* Increased protein synthesis observed in our rat model, may be the consequence of hyperinsulinism (chapters III and IV).

* Increased fatty acid synthesis in adipose tissue may also result from increased insulin levels (chapters III and IV). 
A11 these arguments support a role for insulin in the regulation of plasida BCA levels mediated by the activity of BCOA-DH in adipose tissue.

Objections have been raised agalnst the rolle of insulin in the decrease of BCAA in liver disease because it has been shown that BCAA intolerance and glucose intolerance often exist in patients with liver disease $(13,14)$, due to insulin insensitivity. BCAA Intolerance occurs, in particular, after protein loading. No changes in. insulin receptor characteristics were observed in adipose t1ssue in 1 iver cirrhosis (7). Therefore, BCAA intolerance can only be caused by a diminished capacity to degrade BCA in muscle. This is consistent with the demonstration that BCOA-DH was decreased In muscle (chapter $V$ ). If we hypothesize, total capacity to clear BCAA is apparently reduced in liver cirrhosis, but in the fasting condition, faulty programing of adlpose tissue leads to ongoing BCAA degradation and Iow plasma BCAA levels.

The mechanism of regulation of $\mathrm{BCOA}-\mathrm{DH}$ activity in adipose tissue by insulin is still largely unknown. Recently, it has been demonstrated in vitro that $B C O A-D H$ activity in liver can be influenced by a substance released by muscle, most probably a peptide (18). It is not yet excluded that lnsulin influences the synthesis and/or release of this substance by muscle which subsequenty may exert its influence on the activity of BCOA-DH in adipose tissue. However, this seems unlikely because of the demonstration that $B C O A-D H$ activity in kidney, heart and brain is not Influenced by this muscle released factor.

The next unanswered question concerns the cause for hyperinsulinisin atter PCS and in liver insufficiency. This question is particularly interestlug because, if insulin 15 instrumental in lowering the BCAA levels, the elevated insulin levels are inappropriate in relation to the quantity of food consumed, especially with respect to AA-metabolism because increased decarboxylation of $\mathrm{BCAA}$ and storage of BCAA-derlved carbon into fat $1 \mathrm{~s}$ induced. The increased protein synthesis in muscle also suggests the existence of an extremely well fed state in PCS rats compared to control rats, despite an equal or slightly decreased food intake by PCS rats. Even after an overnight fast, fatty acid synthesis from leucine derived carbon In PCS rats is higher than in fed control rats (chapter III, fig. 3 ). Compared with control rats, PCS rats used in the studies described in this thesis, were leaner, often consumed less food, had less muscle mass 
(evidenced by tissue DNA content and the weights of the diaphragms exclsed) and had less fat (evidenced by tissue DNA content and the welght of the epididymal fat pads excised). PCS rats that did not gain weight and were excluded from the studies described for reasons mentioned (chapters I and II), were more ill, still leaner, had higher insulin levels (and glucagon levels) and exhibited the highest BCAA degradation rates and the highest

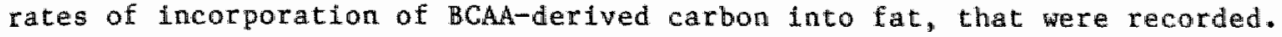
These findings are not at all likely to be caused by malnutrition because the opposite would be expected to occur, but they suggest that the severity of the disease or the amount of stress may be a determining factor in the level of insulin and in the rate of $\mathrm{BCAA}$ catabolism. In this respect, it may be relevant that plasma levels of "stress hormones" are generally reported to be increased in liver cirrhosis $(15,21,22,24,25,26)$. As already mentioned, glucagon levels are increased in PCS rats, but we are not aware of data concerning catecholamines and cortisol in PCS rats. Elevations of all three "stress hormones" are generally accompanied by increases in insulin levels. It is therefore possible that a "stressed state", although clinically not always apparent in cirrhotic patients and incompletely documented in PCS rats, is instrumental in the observed alterations, and that hyperinsulinism may be an integral part of the stressed state.

Recently, owen (17) reported a study in patients with biopsy-proven alcoholic cirrhosis and healthy volunteers, in which the nature and quantity of fuels oxidized was measured after an overnight fast and after a longer period of starvation (only in volunteers). He demonstrated that, after an overnight fast, the caloric requirements of patients with (alcoholic) cirrhosis were normal, but the nature of fuels oxidized (fat carbohydrate - protein) in these patients were similar to normal humans undergoing 2-3 days of total starvation (more fat, less carbohydrate). He concluded that these clrrhotic patients develop the catabolic state of starvation more rapidly than normal humans do. As mentioned before, our in vitro results in PCS rats appear to reflect a well-nourished state and suggest an inappropriate programing of adipose tissue with regard to BCAA. metabolism. The normal fine tuning of net fatty acid synthesis and net fatty acid degradation is disturbed.

This well-nourished state 1s, of course, not present. Where Increased proteln synthesis in muscle colncldes with muscle hypotrophy, increased 
protein degradation must occur, possibly related to the increased catecholamine levels in plasma. In our PCS rats, this was supported by increased urinary 3-methylhistidine excretion. Even an equal 3-methylhistidine excretion might be interpreted as an increased protein degradation because of the smaller muscle mass after PCS and in cirrhosis. These findings indicate increased protein turnover which is also reported in patlents with compromised liver function $(16,27)$. In addition, cirrhotic patients have increased protein requirements to maintain nitrogen balance, compared ith healthy individuals $(27)$. This might be partially explained by compensation for Increased BCAA catabolism in adipose tissue. These findings support the ldea that cirrhotics fall to adapt to starvation $(17,27)$.

The increased fatty acid synthesis in PCS rats is, as with the increased protein synthesis in muscle, accompanied by a smaller fat mass, indicating increased fatty acid turnover. Lipolysis might have been stimulated by elevated levels of glucagon, catecholamines and/or cortisol and is in accordance with the elevated plasma levels of free fatty acids (FFA) in liver disease (9). These increased plasma FFA levels may facilitate fatty acid utilization which is very much dependent on circulating FFA levels, when entrance into cells is not impaired. Such an increased fatty acid utilization, occurring in liver disease, leads to a diminished glucose utilization (19) and a diminished capacity to utilize glucose, resulting in glucose intolerance $(13,14,21)$. In cirrhosis, a strong correlation between slucose intolerance and FFA-levels has been reported (21). The decreased capacity to utilize glucose has been mentioned as a possible cause for hyperinsulinism in cirrhosis.

Increased turnover of protein and fat is also observed after trauma and In sepsis $(1,23)$ and was recently reported also in cancer cachexia (11). In both diseases, stress hormones and insulin seem to be involved. Therefore, the mechanism involved in regulating protein and fat turnover and in changIng BCAA levels, appears to be more general. In malnutrition and long-term starvation in man, a decreased turnover of, protein and fat is observed. Although in rats, the extent of decrease may not be as pronounced as In humans, the fact that, after PCS, protein turnover is increased, suggests that malnutrition does not play a role. 
Another mechanism in lowering plasma BCA levels in PSS and/or compromised liver function has been proposed by Holm and Leweling "They suggested that hyperammonemia intensifies BCAA utilization via stimulation of glutamine synthesis, thereby reducing the glutamate pool whlch is then, at least in part, restored by BCAA degradation in a coupled reaction. This hypothesis is in agreement with the demonstration by Imler (10) that, in liver patients, more glutamine and less alanine was released from muscle compared with healthy controls, and would explain the increased glutamine: alanine ratio. Support for this hypothesis was reported (12). It was demonstrated that continuous infusion of an amonium acetatemamonium bicarbonate mixture into rats decreased the plasma BCAA levels after two hours, and decreased intramuscular concentrations of BCAA six hours after initiating the infusion. The decrease in extracellular BCAA values was preceded by a decrease of glutamate and alandne as well as by an increase of glutamine in both plasma and muscle. These alterations were observed in the absence of significant hyperinsulinism, compared with untreated controls. Therefore, Holm and weweling claim that this mechanism is independent of insulin. Scrutiny of the data reveals that there was a significant increase in insulin compared with the sodium acetate-sodium bicarbonate infused controls, due to a decrease of lnsulin in the sodium-infused group. Eurther support for this "ammonia-BCAA" hypothesis origimates from our own group. In a pllot study we determined in vitro the irreversible decarboxylation of leucine in muscle in the presence of ammonium acetate $(0,0.25,0.50$ and $1.0 \mathrm{mM})$ and confirmed an increase in leucine decarboxylation dependent on the ammonla concentration present in the incubation medium (fig. 1). In addition, we recorded a much more pronounced increase in the irreversible decarboxylation of leucine in adipose tissue in the presence of ammonia (up to at least $0.5 \mathrm{mM}$ ) and a proportional increase in fatty acid synthesls from leuclne-derived carbon (fig. 2). It is conceivable that the activity of the rate-1imiting BCoA-Dit may also play a decisive role in the ammonia-induced BCAA degradation.

The proposed mechanisms mediated by insulin and ammonia may operate simultaneously in vivo, insulin via adipose tissue and ammonla via both muscle and adipose tissue, possibly in part 1 ssulin independent. From our data, it is difficult to draw concluslons about the quantitative effects of these mechanisms on the decrease of plasma BCAA levels. Obvtously, we 
LEUCINE - METABOLISM

diaphragm

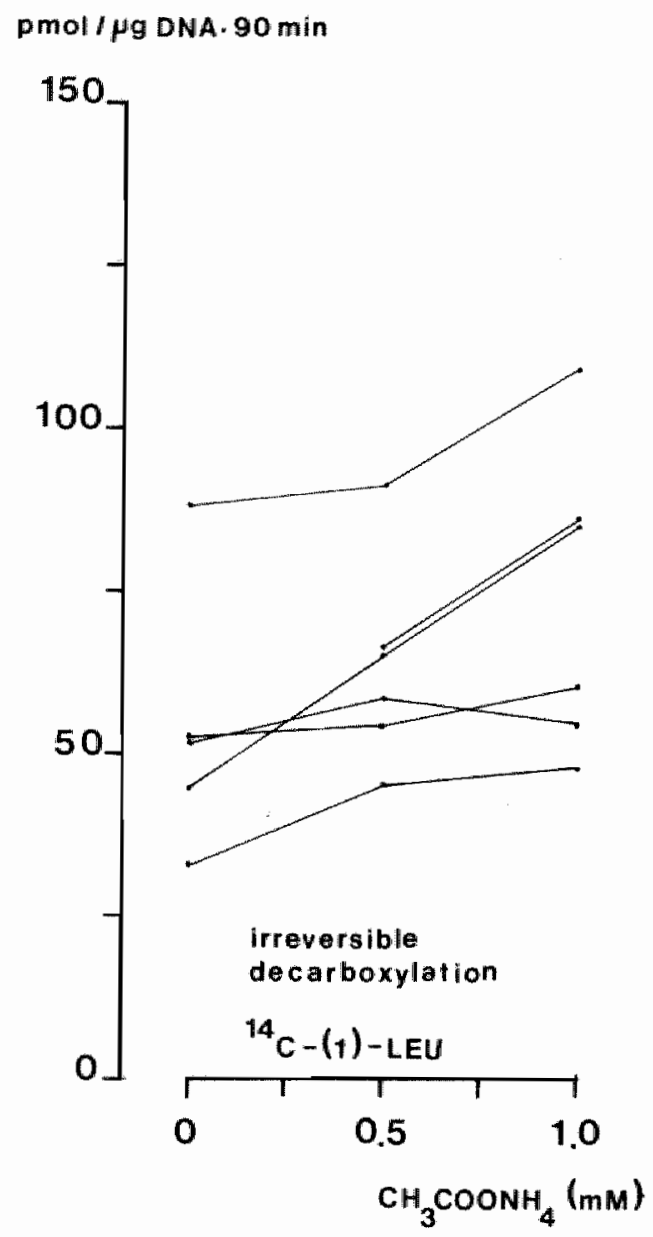

F1gure 1

Influence of ammonia on the irreversible decarboxylation of ${ }^{14} \mathrm{C}-(1)$-1eucine (0.1 mM; s.a. $0.25 \mathrm{mCl} / \mathrm{mmol}$ ) by diaphragm from six nornal rats welghing approximately $280 \mathrm{~g}$. In vitro measurements were carried out in triplicate according to the method described in chapter III. 


\section{LEUCINE - METABOLISM \\ epididymal adipose tissue}
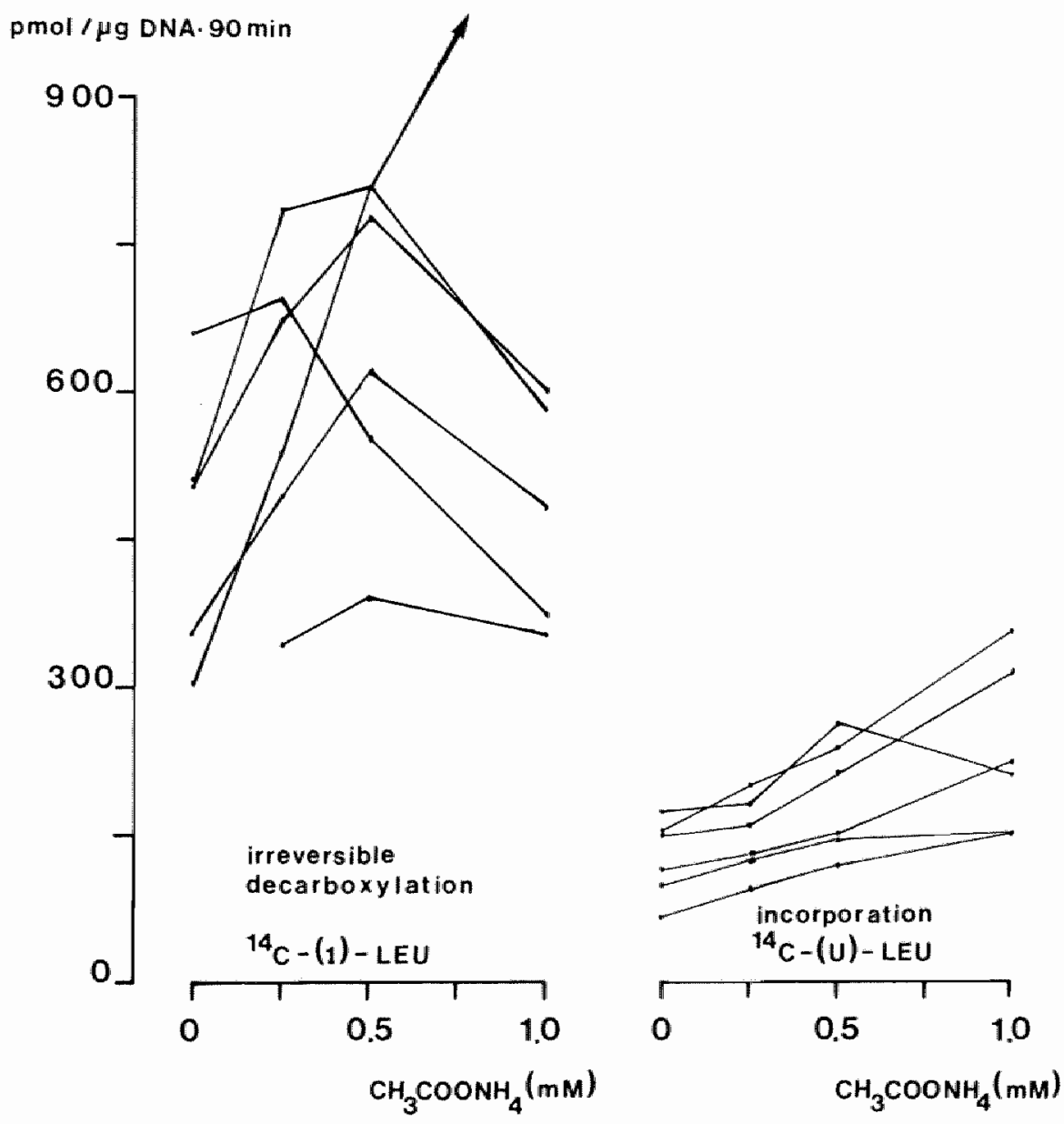

$\frac{\text { Figure } 2}{\text { Influence of ammonia on the frreversible decarboxylation of } 14 \mathrm{C}-(1) \text {-1eucine }}$ $(0.1 \mathrm{mM} ; \mathrm{s.a} .0 .25 \mathrm{mCi} / \mathrm{mol})$ and on the incorporation of ${ }^{14} \mathrm{C}$-(U)-leucine (0.1 mM; s.a. $0.25 \mathrm{mCi} / \mathrm{mmol}$ ) -derived carbon into fat in epididymal adipose tissue from $\mathrm{six}$ normal rats of approximately $280 \mathrm{~g}$. Measurements performed in triplicate and carried out according to the method described in chapter III. 
clearly showed that adipose tissue has a key role in these mechanisms.

A last point to be discussed is the rationale for BCAA enrichment in nutrional reglmens. Do our data support BCAA therapy in patients with compromised liver function? It is still an unanswered question whether the distorted amino acld pattern in these patients, and in experimental animals with compromised liver function, 1 s an imbalanced $A A$ pattern. Do the diminished amounts of BCAA in plasma lead to diminished muscle protein synthesis and/or muscle wasting resulting in inhibition of growth or weight. loss? Increased protein synthesis after PCS in rats and in cirrhotic patients $(16,27)$, and the fact that tissue levels of free BCAA appear to be normal or even increased $\mathbb{i n} 11$ ver patients ( 8 ), argue against the possibility that BCAA are rate-limiting for protein synthesis. If increased protein degradation accurs in an attempt to correct the distorted BCAA levels and to supply substrate for adipose tissue that seems to be programmed for increased BCAA degradation, resulting in net protein loss and less growth, then, supply of BCAA might be useful. In addition, if transamination of BCAA furnishes enough glutamate to decrease plasma ammonia levels by formation of glutanine, administration of BCAA might be useful in patients with liver fallure. It may also be important that, in muscle, BCAA-derived carbon is used for a-ketoglutarate synthesis which is an extremely effectlve ammonia acceptor. Furthermore, it may be questioned whether Increased AAA levels in liver disease are high enough to be toxic when $B C A A$, which compete with AAA for transport across cell membranes and through the blood-brain bartier, are low. Caution should be exerted in administration of imbalanced amino acid mixtures like excess valine (20) or excess leucine (3). Unt1l now, BCAA therapy in liver patients has not been proven to be beneficial. It is beyond a doubt that clinical improvement must play the decisive role in the reglmen followed.

\section{References}

1. Clowes GHA, George BC, Villee CA Jr, et al: Muscle proteolysis induced by a circulating peptide in patients with sepsis or trauma. N Engl J Med 308: 545-552, 1983.

2. Collins JR, Crofford $O B:$ Glucose intolerance and insulin resistance in patients with 11ver disease. Arch Intern Med 124: 142-148, 1969. 
3. Eriksson S, Hagenfeldt L, Wahren J: A comparison of the effects of intravenous infusion of Individual branched-chain anino acids on blood amino acid levels in man. Clin Sci 60: 95-100, 1981.

4. Felber J, Magnenat $P$, Vannotti A: Tolérance au glucose diminuée et résponse insulinique élevêe dans la cirrhose. Schweiz Med Wschr 97 : $1537-1539,1967$.

5. Frick GP, Goodman HM: Insulin regulation of branched chain -keto acid dehydrogenase in adipose tissue. J Biol Chem 255: 6186-6192, 1980.

6. Goodman HM, Frick GP: Metabolism of branched chain amino and keto acids in adipose tissue. In: Walser $M$, Williamson JR (eds): Metabolism and clinical implications of branched chain amino and keto-acids. Elsevier North-Holland, New York, p. 169-180, 1981.

7. Harewood MS, Proletto J, Dudley F, et al: Insulin action and cirrhosis: insulin binding and lipogenests in lsolated adipocytes. Metabolisw $31: 1241-1246,1982$.

8. Holm E, Leweling $\mathrm{H}$, Staedt $\mathrm{U}$, et al: Metabollc fate of branched chain aminoacids. In: Capocaccla L, Fisher JE, Rossi-Fanelli $F^{*}$ (eds): Hepatic encephalopathy in chronic liver fallure. Plenum Publishing Co, p. 161-181, 1984 .

9. Holm E, Staedt U, Leweling H, et al: Fettstoffwechsel und parenterale Fettzufuhr bei Leberinsuffizienz. Infusionstherapie 10: 184-204, 1983.

10. Imler $M$, Schlienger JL, Frick A, et al: Study of muscular glutamine and alanine release in cirrhotics with hyperammonemia and in ammonium infused rats. In: Holm $E$ (hrsg), Verlag Gerhard Witzstrock, Baden-Baden, p. 33-39, 1982.

11. Jeevanandan $M$, Horowitz GD, Lowry $S F$, et al: Cancer cachexia and protein metabolism. Lancet I: 1423-1426, 1984.

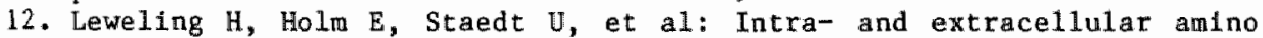
acid concentrations in amronium-infused rats. Evidence that hyperammonemia reduces BCAA levels. In: abstractbook 5th International Symposium on Ammonia, Semmering, Austria, May 16-19, p. 57, 1984 .

13. Marchesini G: Relationship of carbohydrate and amino acid metabolism. In: abstractbook 5th International Symposium on Ammonia, Semmering, Austria, May 16-19, p. 63, 1984.

14. Marchesini $G$, Bianchi G, Zoli M: Plasma amino acid response to protein ingestion in patients with liver disease. Gastroenterolgoy 85: $283-290,1983$.

15. Marco J, Diego J, M1lanueva ML, et al: Elevated plasina glucagon levels in cirrhosis of the 11ver. N Engl J Med 289: 1107-1111, 1973 .

16. O'Keefe SJD, Abraham RR, Davis M, et al: Protein turnover in acute and chronic 11ver disease. Acta Chir Scand Supp1 507: 91-101, 1980.

17. Owen $O E$, Trapp VE, Reichard GA Jr, et al: Nature and quant1ty of fuels consumed in patients with alcohollc cirrhosis. J Clin Invest 72: $1821-1832,1983$.

18. Paul HS, Adibi SA: A possible role for the muscle in the regulation of oxidation of branched-chain amino aclds in the 1iver. In: Blackburn GL, Grant JP, Young VR (eds): Amino acids, metabolism and medical applications. John Wright, PSG Inc, Boston, p.191-199, 1983.

19. Randle, PJ, Hales PB, Garland, et al: The glucose fatty-acid cycle, its role in insulin sensitivity and the metabolic disturbances of diabetes mellitus. Lancet $I: 785-789,1963$.

20. Riederer $P$, Jellinger $K$, Kleinberger $G$, et al: Oral and parenteral nutrition with L-valine: Mode of action. Nutr Metab 24: 209-217, 1980. 
21. Rlgglo 0 , Merli $M$, Cangiano $C$, et al: Glucose intolerance in liver c1rrhosis. Metabolism 31: 627-634, 1982 .

22. Ring-Larsen $H$, Hesse $B$, Henriksen $J H_{*}$ et $a 1$ : Sympathic nervous activlty and renal and systemic hemodynamics in cirrhosis: plasma norepinephrine concentration, hepatic extraction and renal release. Hepatology 2: 304-310, 1982 .

23. Rosenblatt $\mathrm{S}$, Clowes CHA, George BC, et al: Exchange of amino acids by muscle and 1iver in sepsis. Arch Surg 118: 167-175, 1983.

24. Sherwin $R$, Fischer $M$, Bessoff $J$, et al: Hyperglucagonemia in circhosis: altered secretion and sensitivity to glucagon. Gastroenterology $74: 1224-1228,1978$.

25. Sherw $I n$, Josh1 $P$, Hendler $R$, et al: Hyperglucagonemia in Laennec 's cirrhosis. The role of portal-systemic shunting. N Eng $J$ Med 290: $239-242,1974$.

26. Stewart A, Johneton D, Albert1 $K$, et al: Hormone and metabolite proflles in alcohollc 1iver disease. Eur J Clin Invest 13: 397-403, 1983.

27. Swart GR: Eiwitstofwisseling bif levercirchose (Protein turnover in patients with cirrhosis of the liver). Thesis, Erasmus University, Medical Faculty, Rotterdam, 1984. 
ADDENDUM

The degradation pathways of leucine, isoleucine and valine to acetylCoA, acetoacetic acid and succinyl-CoA are depicted below.

To be consistent with the way in which the data were presented in the experimental chapters, table I from chapter I, In which leucine degradation. rates in several tissues were expressed per mg wet tissue welght, is included in this addendum in "DNA-corrected" form.

Most data presented in this thesis were expressed per $\mu \mathrm{g}$ DNA. Interpretation of the uncorrected data (data per mg wet tissue weight) would have been slightly different. Generally, the differences between controls and PCS-operated rat were greater, especially in adipose tissue. In muscle, correction for tissue DNA content sometimes abolished the observed differences, and sometimes even changed the direction of the differences. Therefore, some relevant data presented in this thesis are included in this addendum, expressed per mg wet welght. 


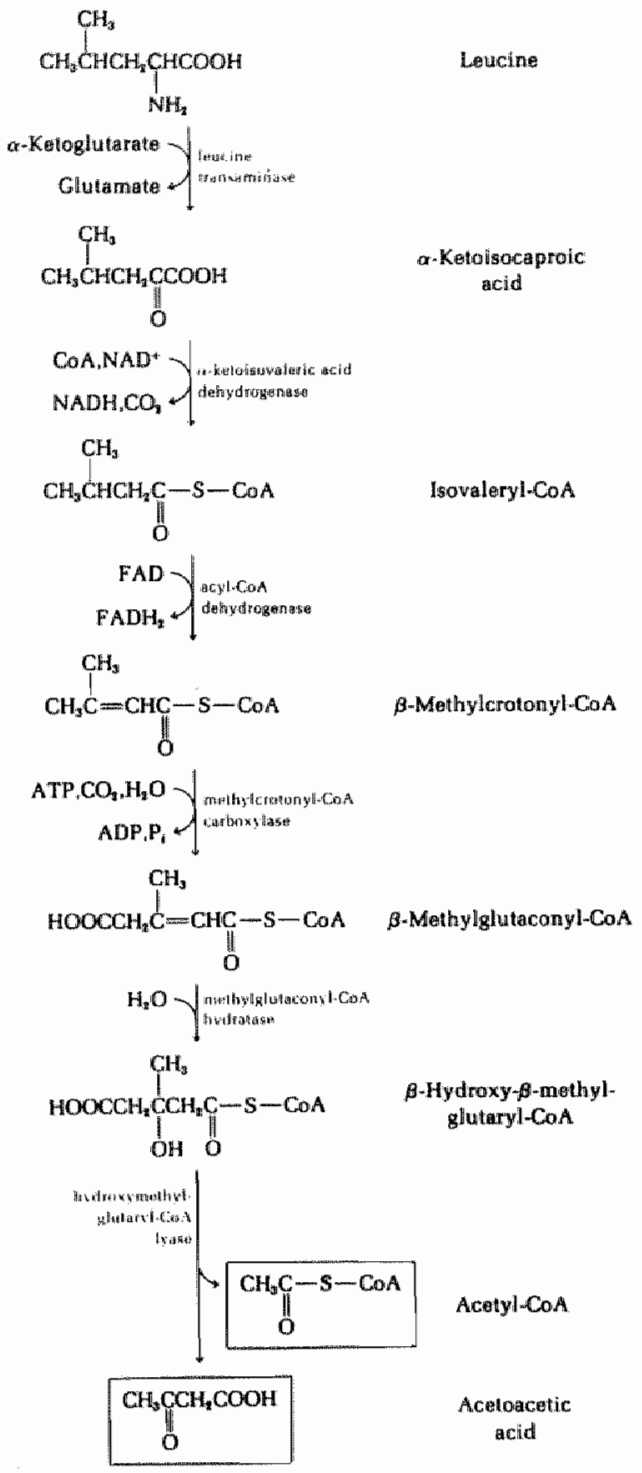

Catabolic pathway of leuclne 


\section{$\left.\mathrm{CH}_{4} \mathrm{CH}_{2} \mathrm{CHCH}_{2} \mathrm{NH}_{2}\right) \mathrm{COOH}$ \\ $\mathrm{CH}_{3}$ Isolencima}

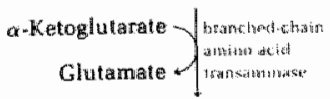

(1)

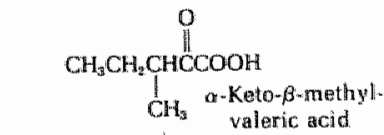

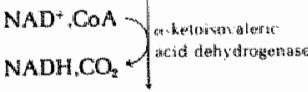<smiles>CCC(C)C(=O)SCC(=O)N[Mg]</smiles>

CoA

FAD<smiles>CC=C(C)C(=O)SC(C)(C)C</smiles>

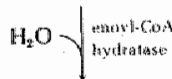

${ }_{\mathrm{OHCH}} \mathrm{CHC}_{3}-\mathrm{S}-\mathrm{CoA}$

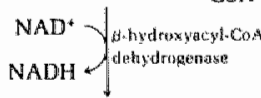

$\mathrm{CH}_{2} \mathrm{CCHCH}_{\mathrm{CH}}-\mathrm{S}-\mathrm{CoA}$

${ }_{0} \quad \alpha-$ Methyll-

$\frac{\mathrm{COA}}{\mathrm{Acetyl-CoA}} \cdot \frac{\mathrm{CH}}{\mathrm{O}}$

$\mathrm{H}_{3} \mathrm{O}, \mathrm{CO}_{2}$ A $\mathrm{TP}-\mathrm{fpropionyl \cdot COA}$

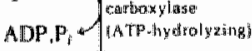

$\mathrm{HCOC}-\left.\right|_{\mathrm{C}} ^{\mathrm{C}}-\mathrm{CH}_{3} \quad \mathrm{D}_{\mathrm{g}}-\mathrm{Meth}-\mathrm{S}-\mathrm{COA}$

mathyitmalowy t-COA

ratemenase<smiles>CCCCCCCCC(=O)OCC(=O)O</smiles>

nnethylmalnny $10 \mathrm{COA}$

muxaร

$\mathrm{HOOCCH}_{2} \mathrm{CH}_{3}-\stackrel{\mathrm{O}}{\mathrm{C}}-\mathrm{S}-\mathrm{CoA}$
$\mathrm{CH}_{3} \mathrm{CHCH}\left(\mathrm{NH}_{2}\right) \mathrm{COOH}$

C.t

Waling

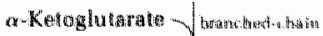

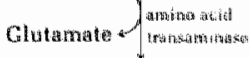

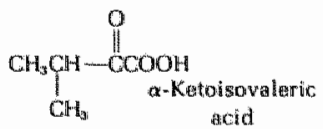

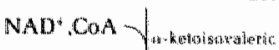

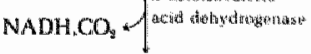<smiles>CC(C)C(=O)SC(=O)[N+](=O)[O-]</smiles>

PAD<smiles>C=C(C)C(=O)SC(=O)OCC</smiles>

$\mathrm{H}_{2} \mathrm{O}-\operatorname{lenanicon}$

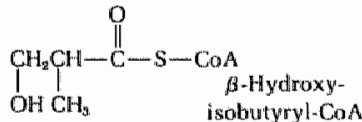

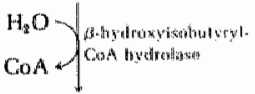

$\mathrm{CHH}_{2} \mathrm{CHCOOH}$

O B.Hydroxy.

OH Cl: isobutyric acid

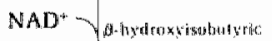

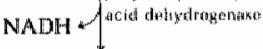

$\mathrm{H}-\mathrm{C}-\mathrm{CHCOOH}$
$\mathrm{O}$ $\mathrm{CH}_{\mathrm{s}}$ Methylmalonic

seminteleliyd

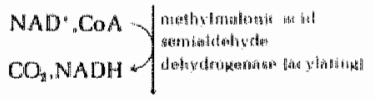

$\mathrm{CH}_{3} \mathrm{CH}_{2} \mathrm{C}_{2}-\mathrm{S}-\mathrm{COA}$

O Propicanyllon 


\begin{tabular}{|c|c|c|c|c|}
\hline & $\begin{array}{l}\text { 1.g. DNA wet } \\
\text { welght }\end{array}$ & $\begin{array}{l}\text { activity } \\
\text { pmol/pg } \\
\text { DNA.90 min }\end{array}$ & $\begin{array}{l}\text { \% of total } \\
\text { based on } \\
\text { skeletal muscle }\end{array}$ & $\begin{array}{l}\text { body activity } \\
\text { based on } \\
\text { diaphragm }\end{array}$ \\
\hline adtpose tissue & 0.41 & 371 & 80.0 & 61.0 \\
\hline diaphragm & 2.16 & 82 & & 36.5 \\
\hline skeletal muscle & 1.01 & 31 & 17.0 & \\
\hline heart muscle & 2.28 & 24 & 0.1 & 0.1 \\
\hline small intestine & 7.64 & 2 & 0.0 & 0.0 \\
\hline bralth & 1.15 & 132 & 1.2 & 0.9 \\
\hline 11ver & 2.91 & 14 & 1.2 & 0.8 \\
\hline kidney & 4.07 & 33 & 0.5 & 0.4 \\
\hline
\end{tabular}

See table I, chapter I

Irreversible degradation of ${ }^{14} \mathrm{C}-(1)-L-l e u c i n e(s . a .0 .25 \mathrm{mCl} / \mathrm{mmol} ; 0.1$ mM) by different organs of normal male sprague Dawley rats $(n=4)$, determined in triplicate and expressed in pmol/ $\mathrm{gg}$ DNA.90 min. Average body weight was $290 \mathrm{~g}$. To be able to calculate the activity per mg wet welght of the tissue, tissue DNA content is listed. A rough calculation of the percentual contribution of each organ is given, based on organ weights and on the assumption that adipose tissue $1815 \%$ of total body weight, and muscle $40 \%$ of total body welght. Because of the different activites that were recorded in diaphragm and skeletal muscle, two calculations are given (see text). 


\section{LEUCINE METABOLISM}

(5 taM ghacose)
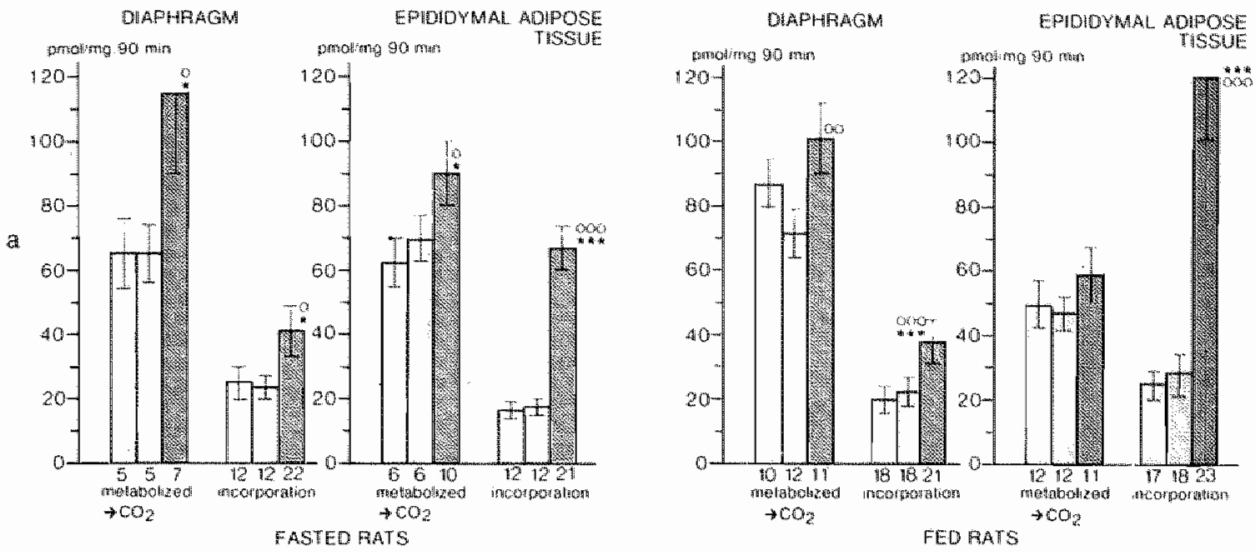

('whlnout glucoses
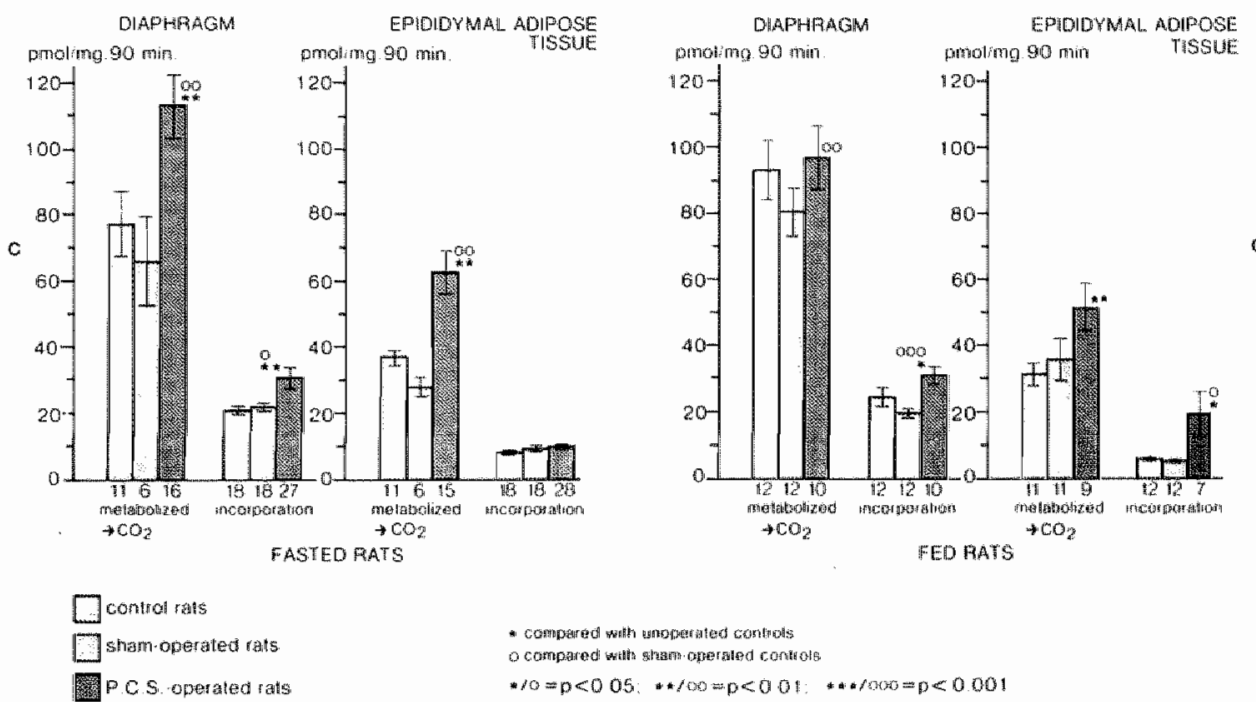

See figure 3 (chapter III) 


\section{LEUCINE METABOLISM \\ ${ }^{14} \mathrm{C}-(1)-L-L E U$ vs. ${ }^{14} \mathrm{C}-(\mathrm{U})-\mathrm{L}-\mathrm{LEU}$}
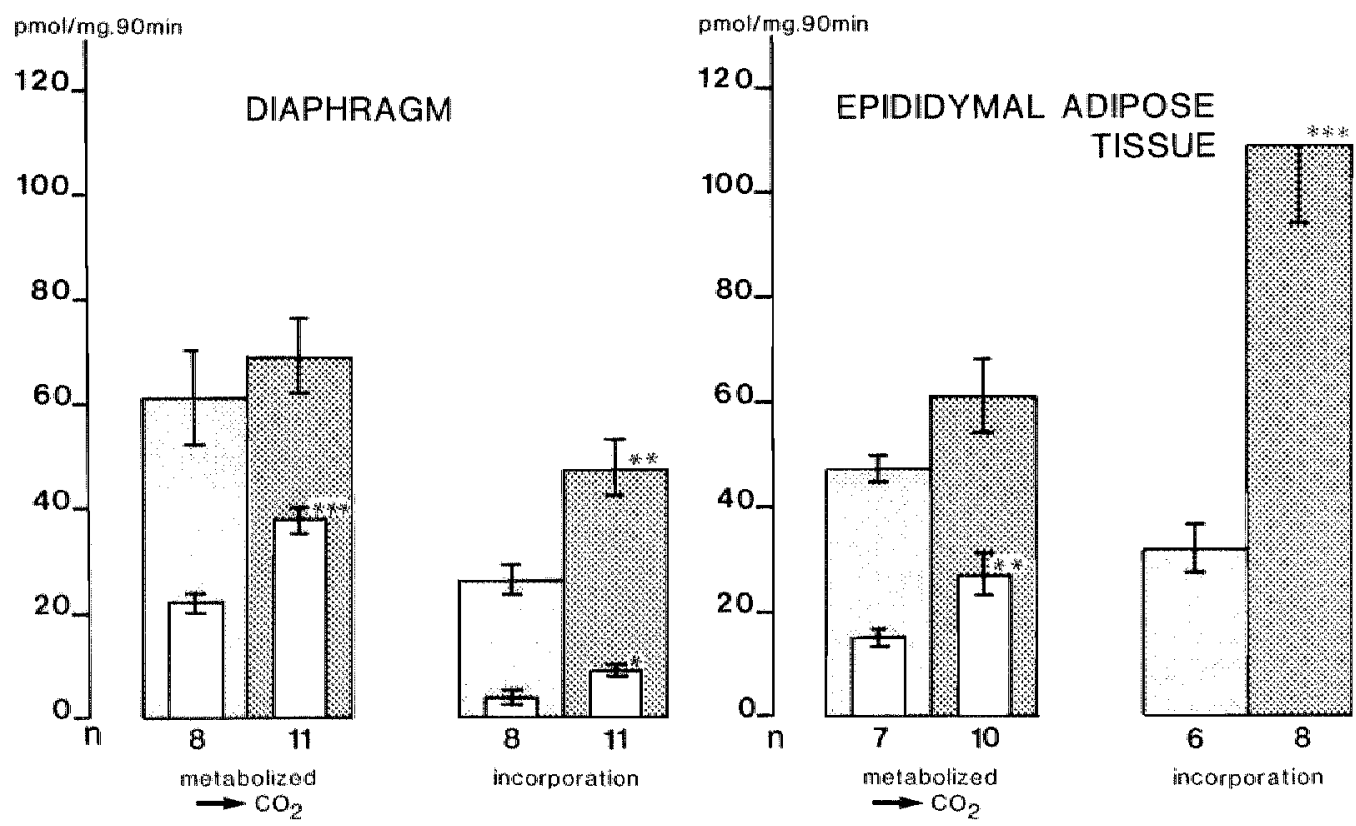

sham operated rats

\# compared wh sham-operated controls

P.C.S. - operated rats

$s=0<0.05 ;$; $0<0.01 ; \quad 0<0.001$

See figure 4 (chapter III) 


\section{BCAA METABOLISM \\ METABOLIZED TO $\mathrm{CO}_{2}$ \\ DIAPHRAGM}

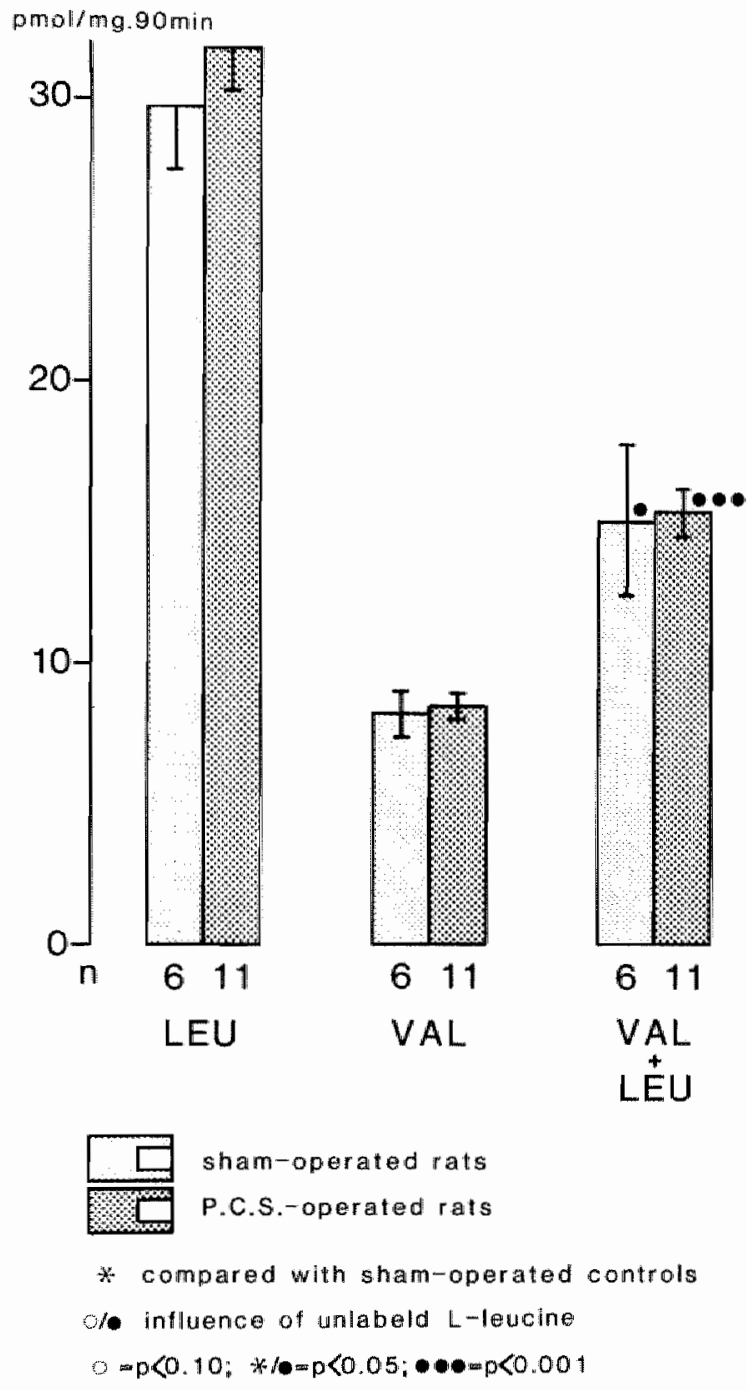

See figure la (chapter IV) 


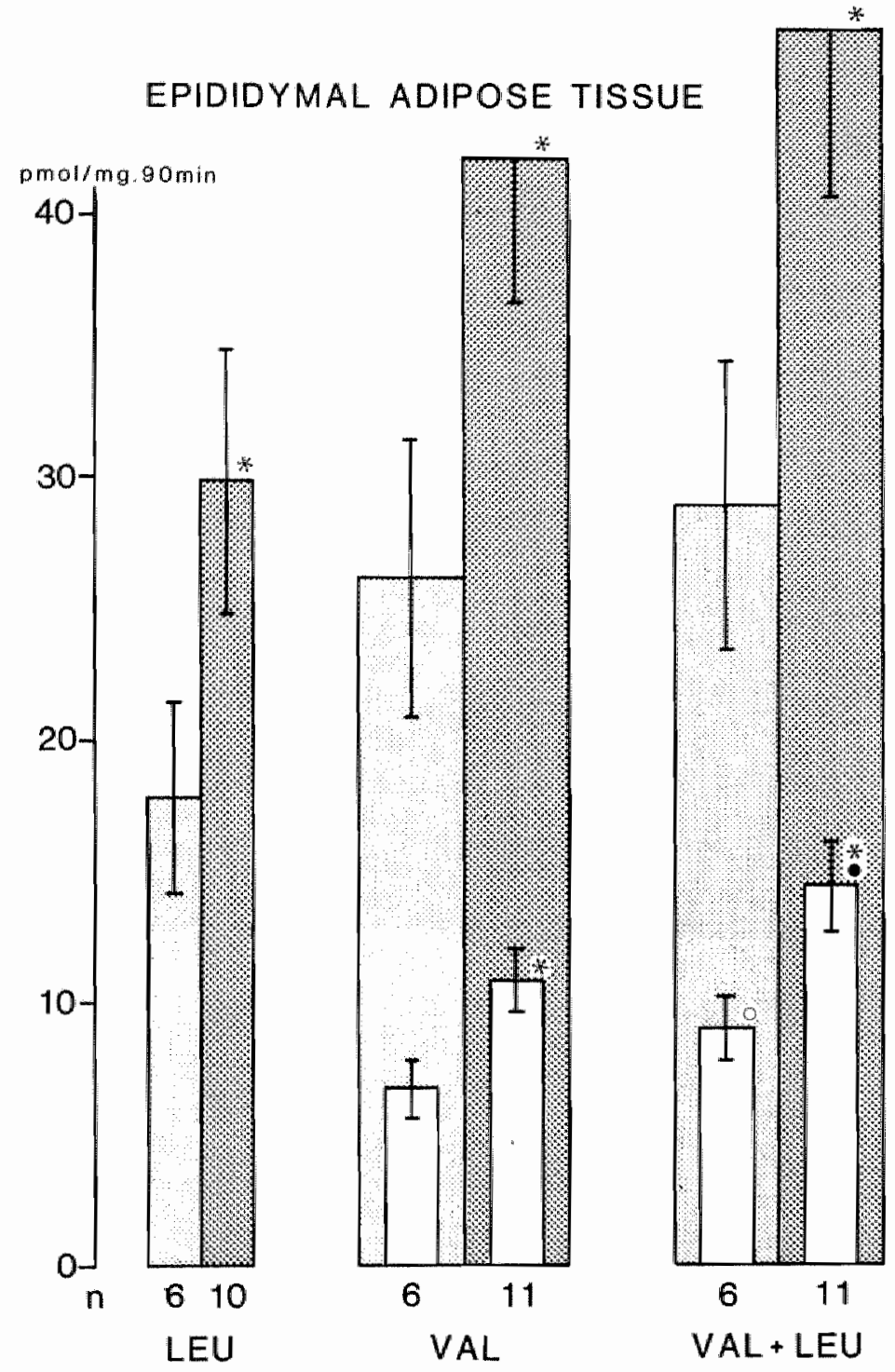

See figure lb (chapter IV) 


\section{${ }^{14} \mathrm{C}-(\mathrm{U})-\mathrm{L}-$ ISOLEUCINE}

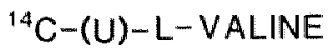

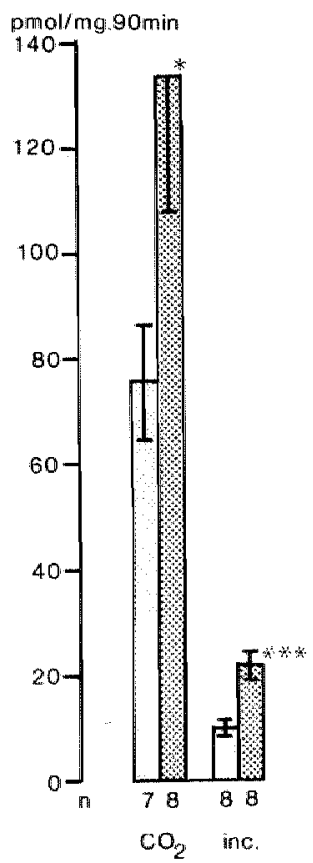

DIAPHRAGM

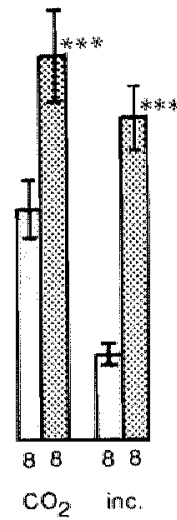

$$
\begin{gathered}
\text { EPIDIDYMAL } \\
\text { ADIPOSE } \\
\text { TISSUE }
\end{gathered}
$$

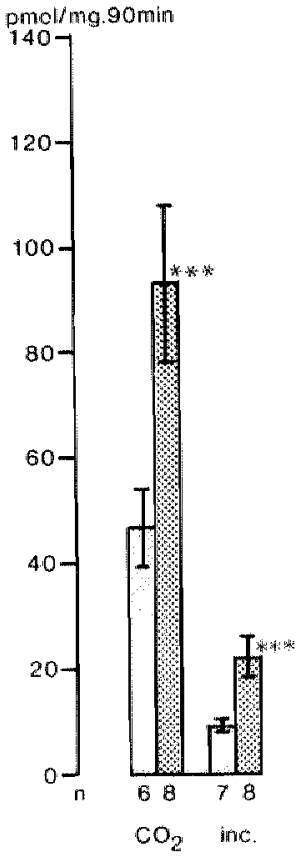

DIAPHRAGM

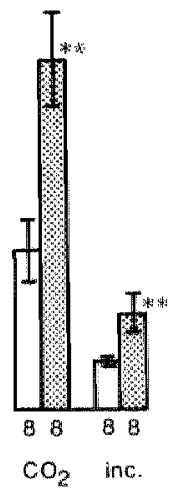

EPIDIOYMAL ADIPOSE TISSUE

\footnotetext{
* compared with shemmoperated controls $*=p<0.05 ; w=p<0.01 ; * w_{*}=p<0.001$
}

See figure 2 (chapter IV) 


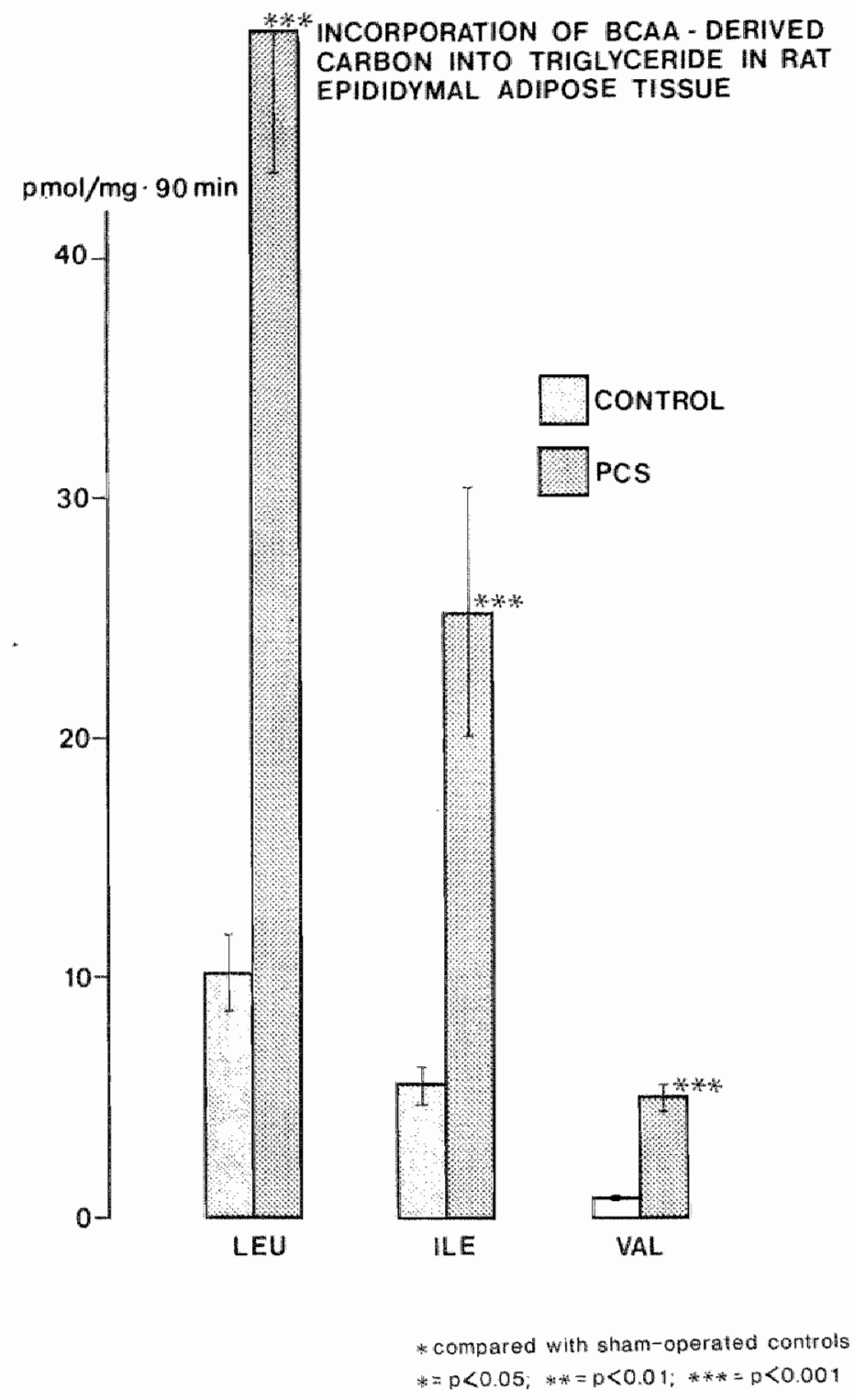

See figure 3a,b,c (chapter IV) 


\section{$\mathrm{BCOA}-\mathrm{DH}$}
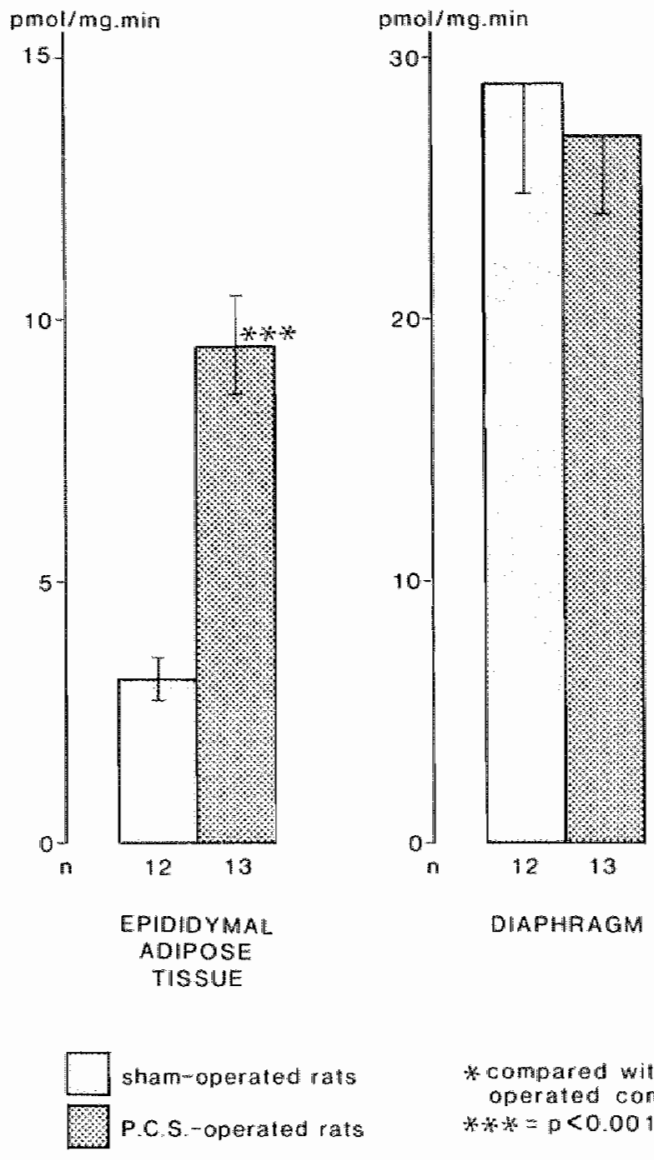
* comparen with sham- aperated cantrals $* * x_{0}=0<0.001$

See figures 3 and 4 (chapter V) 


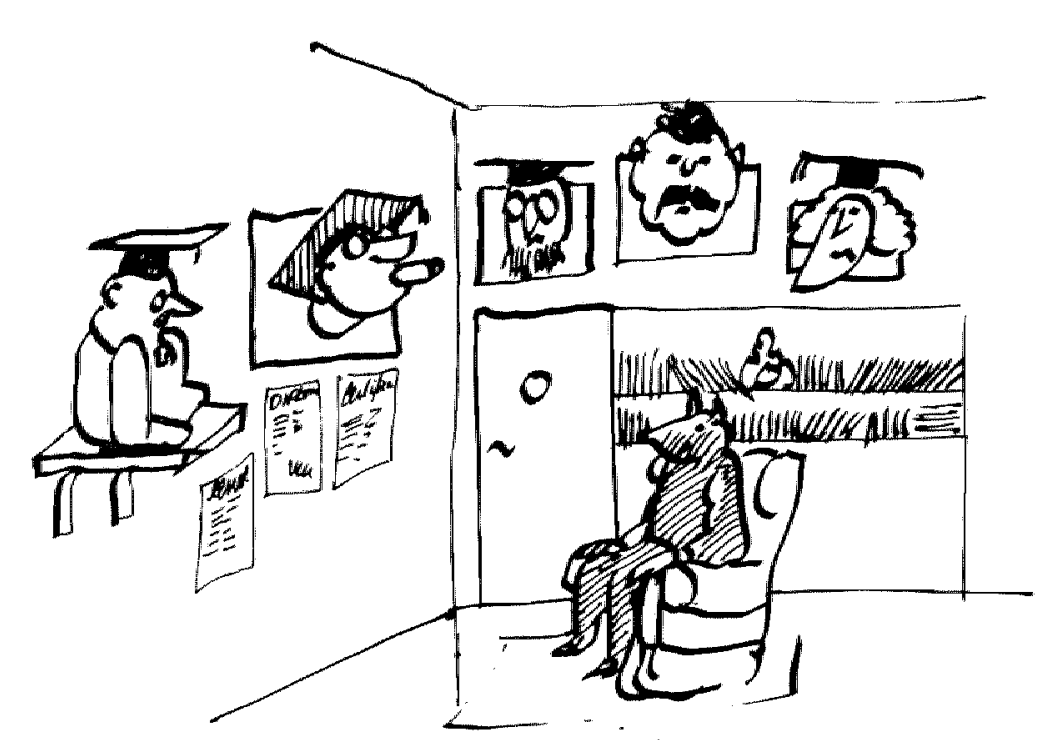


$S \cup M M A R Y$

The subject of this thesis concerns the mechanism(s) involved in the genesis of decreased levels of branched chain amino acids (BCAA) In plasma from patients and experimental animals with liver fallure and portal systemic shunting (PSS). Hyperinsulinism, encountered in liver patients and experimental animals with PSS, has been proposed to be a cause of an increased peripheral uptake of BCAA. This perlpheral uptake, however, has never been well defined. Insight into the mechanism may be relevant to the understanding of the pathogenesis of hepatic encephalopathy (HE) and of the high catabolic rate prevailing $\mathbb{t n}$ hepatic fallure. In addition, a betcer understanding of the regulation of the plasma BCAA levels in pathologic conditions may lead to a rational application of BCAA-enriched infusion solutions in severely catabolic patients with low plasma BCAA levels.

In chapter $I$, a short review is given of the involvement of BCAA In various aspects of clinical interest. The role that BCAA play in several hypotheses, is briefly described. BCAA might serve as alternative energy substrate when carbohydrates and fat are not avallable or cannot be uged $1 n$ sufficient amounts. The validity of this hypothesis is questionable, however, because the contribution of BCAA degradation to overall energy requirement is very smal1. A second hypothes 1 s claims that leuclne, one of the BCAA, has speclal anabollc properties, and functions as a regulator of protein turnover. Furthermore, BCAA are implicated in a hypothesis that links encephalopathy to the altered levels of BCAA and aromatic amino actds (AAA) in the plasma of patients and experimental animals with 1iver fallure and portal-systemlc shunting. These hypotheses furnish the rationale for the admintstration of BCAA-enriched solutions.

Several disease states and altered nutritional states can influence plasma BCAA levels. Some of these conditions may accompany 11ver disease and may therefore exert an additional influence on the plasma BCAA levels. 
The posgible role of several organs and tissues in the in wivo regulation of plasma BCAA levels 1 s discussed. Muscle and adipose tissue must play a predominant role $1 \mathrm{n}$ BCAA degradation judging from the ability to degrade BCAA and from the relative size of these tissues in the body. Some influences that may affect the BCAA degrading ability in vitro, may also be of relevance for the in vivo sttuation. These include transport of BCAA across cell membranes, senstivity of the tissues for Insulin and activities of enymes involved in the degradation of BCAA.

To study mechantsms underlying the decrease of plasma BCAA levels in patients or animals with compromised liver function, an animal model is needed that exhiblts both hyperinsulinism and low plasma BCAA levels. In addition, this anfmal model should not suffer from superimposed disorders that might influence plasma BCAA levels such as, e.g. malnutrition, starvatlons, dlabetes or sepsis. Such an animal model (rats with a porta-caval shunt (PCS)) is described in chapter II. The model was carefully characterized with respect to relevant parameters in relation to the time after the operation. It was found that PCS rats exhibit hyperinsulinism and low plasma BCAA levels untll 3 weeks after operation. Generally, pCS rats in. our Institute were in good health compared with those described in the 11terature.

Muscle (diaphragm) and epididymal adipose tissue segments from PCSoperated and sham-operated rats were excised $2 \frac{1}{2}$ weeks post-operatively and used for in vitro studies of BCAA metabolism (chapters III and IV). Porta-caval shunting did not affect or even decreased the rate of irreverstble degradation of BCAA in muscle but greatly increased this rate in adlpose tissue. After PCS, the rates of decarboxylation of the BCAA in adipose tissue appeared to be increased to the same extent. The part of the BCAA carbon skeleton that remains after irreversible decarboxylation in adiposie tissue, was used for incorporation into fat (malnly triglycerides) or degraded to $\mathrm{CO}_{2}$, Indicating that other pathways of BCAA catabolism in adipose tissue are negligible. In contrast, degradation of BCAA in muscle was incomplete. In adipose tissue from PCS rats were more BCAA degraded, even in the postabsorptive state, than in adipose tissue from fed control rats, indicating that this process is under long-term regulation. It was concluded that adipose tissue is extremely important in the degradation of BCAA. After PCS, this role is even more accentuated and it appears that 
adipose tissue, and not muscle, contributes to the decrease in plasma BCAA levels after PCS. Protein synthesis in muscle and fatty acid synthesis in adipose tissue were increased after PCS. Because of the smaller muscle mass and fat mass in PCS rats compared with controls, these increases Indicate that Increased protein and fatty acid turnover must occur. Increased prom tein turnover has also been observed in cirrhotic patients.

The ability to degrade BCAA in muscle and adpose tissue is mainly decermined by the activity of the branched chatn oxoacid dehydrogenase (BCOA-DH), which is the rate-limiting enzyme in BCAA degradation in these tissues. The activity of this enzyme can be influenced by insulin in addpose tissue, but not in muscle. Based on the BCAA degradation rates, it was postulated that, after PCS, adipose tissue would exhlbit an increased BCOA-DH activity, while this activity in muscle was expected to be unaffected of to be decreased. These expectations were confirmed in experiments described in chapter $W$. This may indicate that elevated insulin levels after PCS Induce an increased $B C O A-D H$ activity in adipose tissue. The relevance of these findings is discussed in chapter VI.

The results furmish support for the hypothesis that hyperinsulinism is instrumental in the decrease of the BCAA levels in plasma after PCS. Increased ammonia levels may exert an additional influence on plasma BCAA levels. The view is expressed that hyperinsulinism is a consequence of simultaneous increases of catecholamines, glucagon and cortisol levels encountered in liver disease and reflecting a stressed state. Findings in rats with diabetes or obesity, exhibiting altered plasma insulin and BCAA levels, suggest that the mechanism Involved in changing plasma BCAA levels may be more general.

Increased protein and fatty acid synthesis and Increased degradation of BCAA in adipose tissue all appear to reflect a well-fed state signalled by increased insulin levels. PCS rats, however, are generally less well-fed than control rats. Increased catabolism occurring In PCS rats, may therefore be induced by insulin, erroneously stgnalling the well-fed state. The BCAA carbon skeletons remaining after decarboxylation were less completely degraded in muscle after PCS which argues against a muscle energy deficit. 
$-152-$

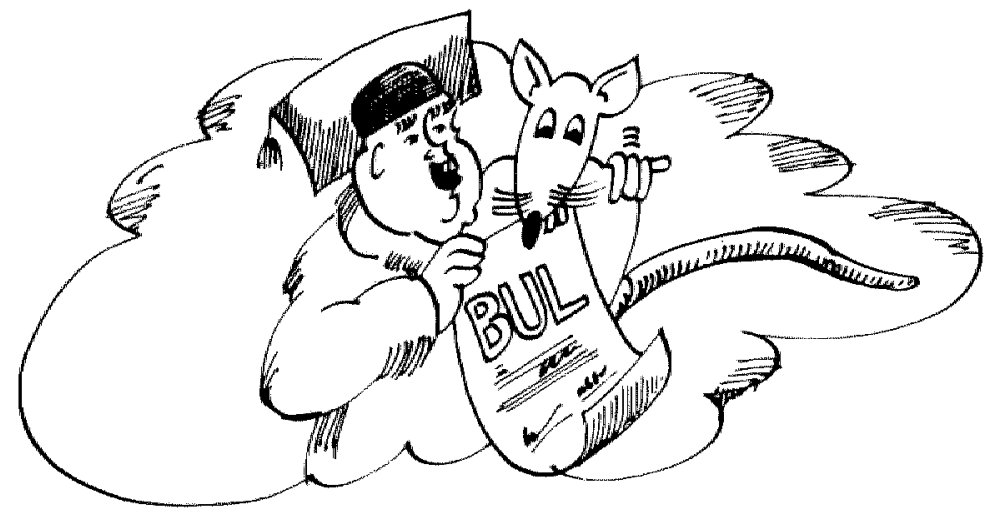


Het onderwerp van dit proefschrift betreft het mechanisme dat verantwoordelijk is voor de verlaging van de splegels van de vertakte keten aminozuren (VKAZ) in het plasma van patienten en proefdieren met leverlijden en shunting van portaal bloed buiten de lever om naar de vena cava (portaal systemische shunting (PSS)). Van oudsher zijn de verhoogde insulinesplegels die bij leverpatienten en bij proefdieren met PSS gevonden worden, genoemd als de mogelljke oorzaak van verhoogde perifere opname van VKAZ, zonder dat precles gespecificeerd is waar en hoe dit gebeurt. Inzicht in dit mechanisme is van belang voor de pathogenese van hepatische encephalopathie (HE) en voor de verhoogde netto afbraak van lichaamseiwit die vaak wordt waargenomen bij leverlijden. Bovendien is een beter begrip van de regulering van plasma VKAZ splegels onder pathologische condities van belang voor een rationeel gebrulk van infusievloeistoffen die verrifkt zijn met WKAZ, in ernstig katabole patienten met lage plasma VKAZ spiegels.

Hoofdstuk I geeft een kort overzicht van die aspecten van de VKAZ, die van belang zijn voor de klinlek. In het kort wordt de rol beschreven die aan de VKAZ wordt toegedacht in verschillende hypothesen. VKAZ zouden kunnen dienen als alternatieve energfebron in situaties waarln koolhydraten en vet niet voorhanden $z i j n$ of niet in voldoende mate gebruikt kunnen worden. Het is echter de vraag of deze hypothese fuist 1s. De bifdrage die afbraak van VKAZ kan leveren aan de totale energlebehoefte, is namelijk maar heel gering. Volgens een tweede hypothese bezlt leuclne, cén van de drie VKAZ, spectale anabole elgenschappen en vervult leucine een regulerende functle bif de opbouw en afbrak van elwitten. Verder spelen VKAZ een rol in een hypothese die een verband legt tussen encephalopathie en veranderde plasma splegels van VKAZ en aromatische aminozuren (AAZ) in het plasma van patienten en proefdieren met leverlijden en portaal-systemische shunting van bloed. Deze hypothesen verschaffen de argumenten om met VKAZ verrijkte voedingsoplossingen toe te dienen. 
Diverse ziekten en weranderde voedingstoestanden kunnen de plasma VKAZ splegel belnvloeden. Enkele van deze invloeden kumen ook optreden bij lever 11 jden.

De mogelijke rol die verschillende organen in viwo hebben in de regulering wan de plasma VKAZ splegels, wordt besproken. Splerweefsel en vetweefsel $z$ In het belangrifkst voor de afbraak van VKAZ, geoordeeld naar het vermogen on VKAZ of te breken en naar de omwang van deze weefsels in het 1ichaam. Het vermogen van weefsels om VKAZ af te breken kan, zowel in vitro als in vivo, belnvloed worden door een aantal factoren. De belangrijkste zijn veranderingen in het transport van de VKAZ over de celmembraan, in de gevoeligheid van de weefsels voor insuline, en in de aktiviteit van de enzymen die betrokken $z \mathbb{1} j \mathrm{jn}$ bij de afbraak van de VKAZ.

Om het mechanisme te kunnen bestuderen dat ten grondslag ligt aan de verlaging van de plasma VKAZ splegels in patienten of proefdieren met een verminderde leverfunktie, dlent beschikt te worden over een proefdier model dat zowel verhoogde plasma insuline splegels heeft als verlaagde plasma VKAZ splegels. Bovendten mogen zich in dat proefdier model niet gelijktijdig andere condities manifesteren die de plasta VKAZ splegels zouden kunnen belnvlaeden, zoals b.v. onderwoeding, hongeren, diabetes of sepsis. Zo"n diermodel (ratten met een porta-cavale shunt (PCS)) wordt beschreven In hoofdstuk II. Het model werd nauwkeurig gedefinfeerd met betrekking tot relevante parameters in relatie tot de tijdsduur na de operatie. Tot 3 weken na de operatie vertoonden de PCS ratten hyperinsulinisme en lage plasma VKAZ splegels. Over het algemeen waren deze ratten in ons instituut gezond, vergeleken met literaturgegevens.

Twee en een halve week na de operatie werden splerweefsel (diaphragma) en epidddymaal vetweefsel van PCS-geopereerde ratten en van controle ratten (sham operatie) gebruikt voor de bestudering in vitro van de metabolisering van VKAZ (hoofdstuk III en IV). De PCS had geen invloed op de mate van irreversibele afbraak van $\mathrm{VKAZ}$ in spierweefsel of verlaggde deze zelfs. In wetweefsel bleek de hoeveelheid VKAZ dle irreversibel werd afgebroken sterk verhoogd als gevolg van de PCS. Alle drie de VRAZ werden in gelijke mate werhoogd afgebroken in vetweefsel wan PCS ratten. Het gedeelte van het koolstofskelet dat overblijft na irreversibele decarboxylering in vetweefsel, wordt via acetyl-CoA Ingebouwd in vet (voornamelijk in de triglyceriden) of wordt verbrand tot $\mathrm{CO}_{2}$. Dit betekent dat andere afbraak routes voor 
VKAZ in vetweefse 1 verwarloosbar $z 1 \mathrm{jn}$. Darentegen is de afbraak van de WKAZ in splerweefsel onvolledig. In vetweefsel wan PCS ratten worden, zelfs na een dag en een nacht vasten, nog steeds meer VKAZ afgebroken dan In vetweefsel van gevoede controles. Dit geeft aan dat dit proces aan lange termijn regulatie onderhevig is. Derhalve mot vetweefsel uiterst belangrijk zijn woor de afbraak van VKAZ. Na PCS is deze rol nog veel belangrijker en het lijkt er sterk op dat vetweefsel, en dus niet spierweefsel, bijdraagt aan de verlaging van de plasma VKAZ splegels na PCS. De efwitsynthese in spierweefsel en de vetzuursynthese in vetweefsel waren verhoogd na PCS. Ondat zowel de spiermassa als de vetmassa in PCS ratten kleiner is dan in controle ratten, betekenen deze verhogingen dat zowel de eiwiturnover als de vetturnover verhoogd moeten zijn. Verhoogde eiwiturnover is ook vastgesteld bij patienten met lever cirrhose.

Het vermogen van splerweefsel en vetweefsel om VKAZ af te breken, wordt voornamelijk bepaald door de aktivitelt van het vertakte keten oxozuur dehydrogenase $(\mathrm{VKOZ}-\mathrm{DH})$, dat snelheidsbeperkend is in de afbraak van VKAZ in deze weefsels. De aktiviteit van dit enzym kan in vetweefsel beinvloed worden door insuline. In spierweefsel is dit niet het geval. Gebaseerd op de hoeveelheden VKAZ die konden worden afgebroken, mocht na PCS een verhoogde VKOZ-DH aktiviteit verwacht worden in vetweefse1, en een onveranderde of verminderde aktiviteit van dit enzym in splerweefsel. Deze verwachtingen werden bevestigd in experimenten die beschreven zijn in hoofdstuk $V$. Dit betekent vrijwel zeker dat de verhoogde insuline splegels die bestaan na PCS, effectief $z i j n$ in de inductie van VKOz-DH aktivitelt in vetweefsel. De relevantile van deze bevindingen wordt besproken in hoofdstuk VI.

De resultaten steumen de hypothese dat hyperinsulinisme bijdraagt tot de verlaging van plasma WKAZ splegels na een porta-cavale shunt. Verhoogde ammoniak spiegels zouden een additionele Invloed op de VKAZ splegels kunnen uitoefenen. Hyperinsulinisme zou het gevolg kunnen zijn van gelijktijdige werhogingen van catecholamines, glucagon en cortisol in het plasma. Deze verhogingen $z 1 j n$ in de literatuur beschreven zijn bif leverpatienten en weerspiegelen een stress-toestand. De resultaten van in vitro studies van de afbraak van VKAZ in vetweefsel van ratten met diabetes of obesitas, dle eveneens veranderde plasma insuline- en VKAZ splegels vertonen, suggereren dat het mechanisme dat zorgdraagt voor de verandering van de plasma VKAZ spiegels, meer algemene geldigheid heeft. 
Een coename wan de elwit- en vetzuursynthese en verhoogde afbraak van VKAZ 1 vetweefsel na PCS 1ijken alle te wijzen op een goed gevoed proefdler, zoals aangegeven door hoge inguline splegels. PCS ratten zijn over het algemeen echter minder goed gevoed dan controle ratten. De toename van elwitafbralk of een verminderde groeisnelheid optredend bij PCS ratten zou daarom langs indlrecte weg veroorzaakt kunnen worden door hoge insuline splegels die een goede voedingstoestand suggereren die in werkelijkheid nlet bestaat. Het koolstofskelet dat overblijft na decarboxylering van de VKAZ, werd na PCS minder volledig afgebroken in diaphragma. Dit pleit tegen de hypothese dat een toename van de afbraak van VKAZ in skelletspler het gevolg zou zijn van een energie tekort in splerweefsel. 
ACKNOWLEDGEMENTS

Many people supported me during the preparation of this thesis. I cannot thank all these people in person, but I want to specifically acknowledge the contributions of those, without whon these Investigations would not have been realized.

In the first place, I am very grateful to Peter soeters, not only for the enormous anount of work that he has done to allow these investigations to be carried out, but also and especially for his warm personallty, something which is not always encountered in the academic world. He initlated this work and guided as far as 1 t could be combined with his clinical work. He, introduced me into the field of liver disease, which is so immense, that in the beginning it was difficult to get an overall picture, and which has become so fascinating to me that I hope to somehow stay involved in it. The clinical relevance of the work especially attracted me. Peter and I spent many days, evenings and week-ends together, sometimes to the exasperation of both families. Publication of this thests proves his valuable engagement in basic clinically-relevant research. He deserved another role at this promotion.

Prof.Dr.F. ten Hoor supported me greatly during the last years of the preparation of the thesis, for which I feel Indebted to him.

Prof.Dr.R.F.A. Zwaal was espectally very helpful with regard to the enzyme-activity studies.

Prof.Dr.P.J. Brombacher equally helped with the completion of this work.

To Prof.Dr.E. Holm (Mannhelm/Heldelberg), I am especlally grateful for many formal and informal discussions, for his knowledge in the fleld and for his interest in our work over the years.

Prof.Dr.P. Fürst (Stuttgart) was a last minute referee. St111, he read the manuscript very carefully and made valuable, critical remarks that have added to the quality of the thesis. For this I feel greatly indebted. 
I an grateful to Prof.Dr.J.M. Greep and Prof.Dr.H.C. Hemker for offertag me facilities in their Departments.

Johan van Dongen provided with his surglcal skill the model which is so difficult to control. He was always joyful or tried to be, even though when it came time to do the experiments, sometimes half of the PCS rats could not be used because they falled to grow.

Mieke Janssen was a great help, especially in the difficult early pertod and in the first phase of the actual experiments.

Hennie Goossens was indispensable during the last years of the work and quietly and conscientiousily got through an enormous amount of work.

Hang van EIjk deternlned the parameters to check the model and helped out whenever necessary.

Rob Oostenbroek stimulated many discussions and helped on days of big expertments.

Ton van den Bogaard, Huub Simons, Paul Hermans, Frans Weekers, Eep van Dam, Malke Peters-Luxembourg and the others of the "centrale proefdieren voorziening" should all be acknowledged for their diligent dealing with the animals (experimental and non-experimental) and their loyal collaboration.

Marcla van Pulfenbroek and Gerda Moers-Haemers did the bulk of the secretarlal work in their inimitable way.

Marlet Molenaar, Iny van Rees and Francis Lankkamp helped when it was needed most and managed to finish the manuscript before the deadline.

Margaret Rand greatly helped with the English.

I want to express my gratitude to the people of the "instrumentele dienst", of the photography department (Cor Evers) and to all those people of the Departments of Blochemistry and Surgery for showing their interest.

Finally, last but not least, I want to thank Marianne for her enducance, understanding and, especlally during the last months, for her enormous support, which allowed me to finish this thesis. 
CURRICULUM VITAE

Jurjen de Boer was born on May 10 th 1948 in Amsterdam. After graduation from high school (Ir. Lely Lyceum, $\mathrm{HBS}^{\mathrm{B}}$, Ansterdam) in 1967, he studied to become a technician. From 1968 to 1969, he served Her Majesty in the military service. Thereafter, he worked as a techniclar at the Central Laboratory of the Netherlands Red Cross Blood Transfuston Service in Amsterdam (1969-1975) In the Department of Blood Cell Chemistry (Dr. H.K. Prins, Dr. J.A. Loos, Dr. D. Roos and Dr. Ir. P. Diepenhorst) and in the laboratory for diagnosis and research on serum-hepatitis B virus (Dr. H.W. Reesink). There he was involved in the following fields; red blood cell. enzyme deficiencies; 1ymphocyte-carbohydrate metabolism; preparation of leucocyte- and platelet-poor erythrocyte suspensions to be used into nephron dialysis patients with chance of transplantation or with antibodies against leucocyties and/or platelets; development of sensitive diagnostic tests for serum hepatitis $B$ surface antigen; and development of heat-inactivated serum hepatitis $B$ vaccine for active immunization. In his free time, he studied to become a labotatory assistant (HBO ${ }^{3}$-blochemistry; graduation 1971) and for a teachers degree, specializing in chemistry and physics (MOA; graduation 1975). He then studied at the University of Amsterdam and in 1976, did his candidates examination in chemdstry and physics. He continued his study in the Department of Blochemistry (BCP Jansen Institute, University of Ansterdam; Prof. Dr. J.M. Täger, Dr. R. Wever, Dr. A.R.J. Bakkenlst), where he was concerned with myeloperoxidase-ligand binding. His secondary field was clinical chemistry which he practised in the Haemostasis Laboratory of the Wilhelmina Gasthuls, University of Amsterdam (Dr. J.W. ten Cate); there he was concerned with characterization of clotting factor XII activity in the urine of a patient with nephrotic syndrome. Furthermore, he qualified in virology. He graduated as a blochemist in 1978 . 
From 1979 to 1984, he worked as a research sclentist at the University of Limburg, Mastricht, In the Departments of Biochemistry and Surgery, where this dissertation was prepared. 